Portland State University

PDXScholar

$9-20-2021$

\title{
Finding a Community Niche: Rethinking Historic House Museums in Oregon
}

Liza Julene Schade

Portland State University

Follow this and additional works at: https://pdxscholar.library.pdx.edu/open_access_etds

Part of the Cultural History Commons, and the United States History Commons Let us know how access to this document benefits you.

Recommended Citation

Schade, Liza Julene, "Finding a Community Niche: Rethinking Historic House Museums in Oregon" (2021). Dissertations and Theses. Paper 5809.

https://doi.org/10.15760/etd.7680

This Thesis is brought to you for free and open access. It has been accepted for inclusion in Dissertations and Theses by an authorized administrator of PDXScholar. Please contact us if we can make this document more accessible: pdxscholar@pdx.edu. 
Finding a Community Niche:

Rethinking Historic House Museums in Oregon

by

Liza Julene Schade

A thesis submitted in partial fulfillment of the requirements for the degree of

Master of Arts

in

History

Thesis Committee:

Katrine Barber, Chair

Patricia Schechter

Thomas Luckett

Douglas Wilson

Portland State University

2021 
(C) 2021 Liza Julene Schade 


\begin{abstract}
$\underline{\text { Abstract }}$
This thesis discusses current preservation and public history in the field of historic house museums in Oregon, looking at two case studies that are undergoing processes of reinterpretation. The first chapter provides a brief history of heritage preservation in the United States, describes the spectrum of historic homes, and presents a key framework of four factors that need to be addressed when evaluating sites today. Current methodology refers to reinterpretation of sites to be more diverse, working with collections, doing research and restaging, along with innovating new programs. Public access and engagement pertain to finding a unique niche in the community that fosters participation and support and creating an inviting educational space. Board capacity and funding are also keys to responsible legal and financial stewardship. Under a 2018 grant, staff at Stevens-Crawford Heritage House in Oregon City cleaned out collections and restaged the property and are now working on creating new digital assets and public programming. Since 2019, a similar project has been in process at the Hollinshead-Matson Historic House and Tack Shed in Bend, Oregon. Both sites have become models for reinterpretation of other museums in this state. While work is ongoing, their success inspires other organizations to push for reinterpretation, updates to policy and practice, and creation of new collaborative partnerships. Most importantly, historic house museums are inviting volunteers, interns, and stakeholders to participate at every step of the way.
\end{abstract}




\section{Dedication}

To my late grandmother, Elna Mae Purnell Pierson.

I honor you by honoring the past. 


\section{Acknowledgements}

Dr. Katrine Barber, thank you for ten incredible years of teaching and mentorship and for supporting my career as a public historian.

Professor Patricia Schechter, thank you for pushing me to be a better researcher and oral historian, and for being such a wonderful mentor and role model.

Jenna Barganski and Johna Heintz, thank you for trusting me to help with the StevensCrawford house project and for years of friendship and support.

Kelly Canon-Miller, Julie Brown and Kim Johnson, thank you for inviting me into the project at Hollinshead Park and I am so proud of the commitment your organizations are making toward collaboration.

Tony Rosengarth and Sharron Matson Rosengarth, thank you for opening your hearts and sharing your memories, and for your dedication to Hollinshead Park.

Kuri Gill, thank you for sharing your considerable knowledge about house museums in our phone conversation in May 2020, which inspired the title and theme of this thesis.

Professor Thomas Luckett and Professor Douglas Wilson, thank you for years of invaluable instruction in academics and leadership, and for your willingness to review my thesis work.

Kay Demlow and Judy Goldmann, thank you for being incredible historians, mentors, and friends and for pushing me to be a better professional and community role model.

Tim Schade, my loving husband, thank you for supporting me through countless hours of classes, research, and volunteering in the community. 


\section{Table of Contents}

$\begin{array}{lc}\text { Abstract } & \text { i } \\ \text { Dedication } & \text { ii } \\ \text { Acknowledgments } & \text { iii } \\ \text { List of Figures } & \text { v } \\ \text { Acronyms } & \text { vi } \\ \text { Chapter One: A Framework for Rethinking Historic House Museums } & 1 \\ \text { Chapter Two: Stevens-Crawford Heritage House } & 50 \\ \text { Chapter Three: Hollinshead-Matson Historic House and Tack Shed } & 84 \\ \text { Epilogue } & 123 \\ \text { References } & 131\end{array}$ 


\section{List of Figures}

Figure 1: Liza Schade, iPhone image of the Stevens-Crawford Heritage House, Oregon City, Oregon. Taken by Spring 2019 .......................................................50

Figure 2: Liza Schade, iPhone image of the Hollinshead-Matson Historic House,

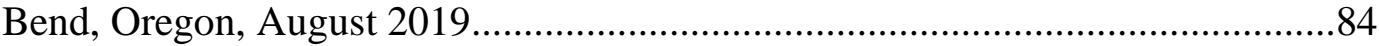


Acronyms

BPRD: Bend Park and Recreation District

DCHS: Deschutes County Historical Society

COIC: Central Oregon Irrigation Canal

HMHH: Hollinshead-Matson Historic House (\& Tack Shed)

MVLA: Mount Vernon Ladies Association

NACW: National Association of Colored Women

NCPH: National Council on Public History

NHL: National Historic Landmark

NHPA: National Historic Preservation Act (1966)

NPS: National Parks Service

NRHP: National Register of Historic Places

PSU: Portland State University

SCHH: Stevens-Crawford Heritage House

SHPO: State Historic Preservation Office

WFLHAC: Willamette Falls Landings \& Heritage Area Coalition 


\section{Chapter One}

\section{$\underline{\text { A Framework for Rethinking Historic House Museums }}$}

Historic house museums are interdisciplinary sites of public history and preservation, where visitors can have a tangible and "personal participation" with the past. ${ }^{1}$ Once an old home is preserved and curated, the structure can never again be original, but the goal is usually to provide as close to that state as possible. Places of habitation not only inspire admiration for early architecture, lifeways, and narratives, they deepen public understanding of historical context and influence heritage activism. Imagining alternative uses, inviting open collaboration, increasing public commentary, and broadening context have all become fundamental to the sustainability of the heritage field today. Participating in the most recent historic preservation movement, staff are actively "in transition" to rethink their house museums and find a niche in the community, by preserving collections, re-curating exhibitions, experimenting with new interpretive methodologies and innovating new strategic plans for long-term care. ${ }^{2}$

Stewards of house museums face many challenges and must be knowledgeable in a wide variety of crucial subjects, including history, architecture, archaeology, heritage management, historic preservation and many other cultural fields. ${ }^{3}$ In addition to deep and broad content knowledge, boards need to efficiently and legally manage their

\footnotetext{
${ }^{1}$ Roy Rosenzweig and David Thelen, The Presence of the Past (New York: Columbia University Press, 1998), 105.

${ }^{2}$ Kenneth Turino and Max van Balgooy, Reimagining Historic House Museums: New Approaches and Proven Solutions (New York: Rowman \& Littlefield, 2019), 3.

${ }^{3}$ Paul Ashton and Alex Trapeznik (Eds.), What is Public History Globally? Working with the Past in the Present, (New York: Bloomsbury, 2019), 151.
} 
organizations, maintain prudent budgeting practices, employ active public engagement and marketing and physically maintain their properties, along with a host of other complicated responsibilities. Even further, staff must now connect visitors to broader notions of social, national, transnational, and global culture. The historian must look for more diverse perspectives of the past, while at the same time, gathering new ones from those living in the present. In other words, visiting a historic home was once a simple experience rooted in the depth of time, but sites must now teach the public a complicated application of past lessons to larger present issues.

The top priority is to engage people as contributing stakeholders who can support a sustainable future for heritage preservation and each unique community. Public interest and financial support for historic sites have waxed and waned over time, beginning with nineteenth century curiosos who congregated "under the banner of antiquarianism." Since then, the fields of history and preservation have evolved from early philanthropy to an attempt to revitalize through development, to realizing a need to research, interpret and present a broader context, complexity, and continuity of history. Now, active implementation of new methodologies and narratives based on diversity, equity, and inclusion, along with accessing the desires and interests of the public, are all important to the field of historic house museums.

According to authors Roy Rosenzweig and David Thelen, "Americans put more trust in history museums and historic sites than any other sources for exploring the past," which means that they have a responsibility to be dependable and accountable, particularly in

\footnotetext{
${ }^{4}$ Norman Tyler, Ilene R. Tyler and Ted J. Ligibel, Historic Preservation: An Introduction to its History, Principles and Practice (New York: WW. Norton \& Co, 2018), 37.
} 
practice and collaboration. ${ }^{5}$ Many house museums in Oregon are struggling to find a relevant place in their community, along with enough funding and support to aid in successful completion of projects. Tapping a new vein of public interest by asking what each community needs can help to determine what steps to take and how to find grants and donations that enable action. Reinterpretation through new narratives, policies and practices continues to push preservation forward during this time of professional momentum and open new possibilities for partnerships and support.

This thesis addresses the current need for reinterpretation of historic house museums in Oregon, looking at two case studies as models that are undergoing projects. Prior to returning for graduate work at Portland State University in 2018, I worked as a county museum collections registrar and curator, caring for about ten thousand physical objects and one hundred thousand archival records and images. Working directly with historic collections, creating exhibitions, and teaching the public provided invaluable experience that made me a skilled and knowledgeable asset at both case studies represented in this study. As a manager, I had also collaborated with other non-profits throughout the Willamette Valley, which made my network beneficial to procuring private tours of other sites, speaking with professionals, and getting advice from peers and colleagues in the fields of history and archaeology. As an active public historian, I wanted to research projects being conducted at historic sites in my own home state and personally learn about and contribute to modern preservation practice.

\footnotetext{
${ }^{5}$ Roy Rosenzweig and David Thelen, The Presence of the Past: Popular Uses of History in American Life (Columbia University Press: New York, 1998), 105.
} 
Additionally, I am secretary of three separate historical society boards, one of which is an historic house site, and I have participated in and helped to produce reenactments, cemetery tours, local cable videos, and other related activities throughout the community. Due to my experience and relationships, I was given keys to both sites and trusted to complete projects according to my own methodology and planning, under little supervision. After I conducted research and fieldwork between 2018 and 2020, it became clear that context was needed to properly develop a framework for studying historic homes. A graduate-level cultural resource management class helped me to understand the laws, regulations, and activism related to saving heritage sites over time. While only two case studies are discussed here, all my professional and graduate experience, along with research and volunteer work at other sites around Oregon have contributed to development of a greater thesis argument. I assert that reinterpretation of sites, along with increased public access and engagement, board involvement and availability of funding, are all necessary for the sustainability of historic house museums in Oregon.

The first half of this chapter establishes a foundation for understanding the current needs of house museums with a chronological history of preservation movements in the United States, from the mid-nineteenth century through present day. The second half of the chapter outlines the spectrum of historic homes in Oregon and factors that affect public sites today, creating a framework that supports discussion of the two main case studies. While conducting fieldwork and various site visits, four factors consistently determined whether projects could be accomplished. While they are separated below for clarity, it is important to remember that they are highly interconnected and often overlap. 
Other outside challenges may also come into play, but many of those additional aspects can generally be included under the four factors that I believe are the most crucial to the sustainability of public history and preservation in historic homes.

The second chapter of this thesis discusses the first case study: the Stevens-Crawford Heritage House, in Oregon City. Over two academic years, I completed one public history class connected to the site, where I acted as team leader, and one individual internship in collections. I also completed research hours looking into archival records and board minutes on the property history, but the pandemic restricted access, thus creating a two decade gap that will have to be researched later. The third chapter analyzes the Hollinshead-Matson Historic House and Tack Shed, in Bend, Oregon. Fieldwork completed at this site in the summer of 2019 included a detailed inventory of collections, with catalog numbers and images, an assessment of the site, and creation of a video for online use by project partners. Research at the county museum and parks district, along with an oral history interview with a former resident of the house, lent a full background of the property as well. Work completed at this site provided important data that directly contributed to an application for grant funding, which was awarded in December 2019 to the team working on reinterpretation. I also returned to the site again as a volunteer in the summer of 2020 to pack collections with supplies bought under the grant award and give advice about restaging.

The epilogue of this thesis briefly reflects on the main two case studies, the importance of the graduate work completed at the sites, along with implications for public history and preservation fields. Then I will make final arguments for reinterpretation and 
increased public access and engagement, board capacity and funding support for historic house museums across Oregon.

\section{History of Preservation Movements in the United States}

There have been three main waves of preservation in national history and a fourth is now in progress, where the focus is on becoming a "powerful and integral" influence on equity and social justice within communities, not just showcasing prominent properties. ${ }^{6}$ The first preservation movement was inspired by female grassroots philanthropical groups working through the second half of nineteenth century. Early twentieth-century legislation and creation of historical societies and urban districts helped to foster organization and preservation as well. However, a tunneled outlook "encouraged historians to disconnect from present-day issues" and focus mostly on architectural aesthetics, national mythology and prominence when identifying historic sites. ${ }^{7}$

The major activism of the Civil Rights era through Vietnam War, loss of important sites to urban development, and the emergence of social and public history as academic fields, all made a positive impact on heritage preservation. Controversy over demolition of landmark sites culminated in the 1966 National Historic Preservation Act (NHPA) and inspired the second major preservation movement. Urban revitalization was a major goal of the act, with the plan that listing historic properties on the National Register would rescue them from disrepair or demolition, clean up neighborhoods and promote business and tourism. However, collaborations between grassroots organizations were soon

${ }^{6}$ Tyler, 2.

${ }^{7}$ Ashton, 146. 
overshadowed by elitist urban development, working only for profit by increasing ethnic displacement and systematically gentrifying cities. Professionalization of the academic fields of social and public history also began during this time, which evolved the work of historical societies, created cataloging systems for collections and encouraged listing of eligible properties. African American's also made an impact in the field of historic homes and debated the creation of national museum dedicated to their history and culture.

From the 1980 s to early 2000 s, changes in historical thinking inspired the third wave in preservation, which focused on diversification and combatting those effects of gentrification from the second movement. This period of activism specifically pinpointed the "displacement of the poor from revitalizing urban districts," bringing attention to major cities that were replacing downtown ethnic neighborhoods with condominiums and sports centers. ${ }^{8}$ Today, professionals are participating in the fourth movement, where old paradigms are being thrown out and alternative methods that support diversity, equity and inclusion are being implemented. Simultaneously the "digital revolution" is innovating all fields, providing opportunities for greater public access to information and ways to apply history to education, especially through videos, social media platforms and online archives. $^{9}$

The first major historic home was preserved by influential white American women. Pamela Ann Cunningham founded Mount Vernon Ladies’'Association (MVLA) in 1853 at the behest of her mother, who had seen that the grounds and mansion once owned by

\footnotetext{
${ }^{8}$ Max Page and Marla R. Miller (Eds.), Bending the Future: 50 Ideas for the Next 50 Years of Historic Preservation in the United States (Boston: University of Massachusetts Press, 2016), 189.

${ }^{9}$ Douglas Boyd A. and Mary Larson (Eds.), Oral History and the Digital Humanities (New York: Palgrave MacMillan, 2014) 5.
} 
President George Washington were falling into disrepair. Cunningham appealed to wealthy women from every state to create the first female-led heritage organization, with the goal of transforming Mount Vernon into a public site open to visitation. By 1858, the group raised enough money to purchase the property from Washington's family, who were initially reluctant to sell to a female organization. However, after several years of negotiations, planning, fundraising and structural work, the first historic house museum in America was finally ready to cut the ribbon. ${ }^{10}$

Initially, the MVLA focused on continually restoring the home and Washington's nearby gravesite, but for many years presented the property to paid visitors as a "dead artifact without active interpretation," typical for the not yet professionalized standards of that day. ${ }^{11}$ After the turn of the twentieth century, the MVLA built a wharf on the Potomac River to receive visitors, installed Thomas Edison's electricity and even brought in a Ford firetruck for faster response time in case of disasters. Just after World War II, the group purchased the property directly across the river, so guests to Mount Vernon could enjoy the same view that Washington had throughout his life.

Few other house museums have tugged at the "heartstrings" of tourists, due to George Washington's mythic status, but the early work of the MVLA sparked the formation of later women's groups who wanted to preserve historic homes and sites around the country. ${ }^{12}$ After 1870 the "urban revitalization movement picked up momentum," as the

\footnotetext{
10 “Mount Vernon Ladies Association: 150 Years of Saving Mount Vernon," Mount Vernon Ladies Association, Accessed Fall 2020. Link: https://www.mountvernon.org/video/watch/the-mount-vernonladies-association-celebrating-150-years-of-saving-mount-vernon

${ }^{11}$ Donna Ann Harris, New Solutions for House Museums: Ensuring the Long Term Preservation of America's Historic Homes (Rowman \& Littlefield: Lanham: Maryland, 2007), 9.

12 Harris, New Solutions, 7.
} 
Second Industrial Revolution threatened to demolish seventeenth and eighteenth century buildings for tenements and skyrises, due to population growth and big business. ${ }^{13}$ The MVLA became an "early model for organizations involved in saving landmark structures," such as the Ladies' Hermitage Association (LHA) and the Daughters of the American Revolution (DAR). ${ }^{14}$ Seven prominent white women created the Ladies Hermitage Association by applying for a Tennessee state charter in 1889 to purchase and maintain the historic estate of President Andrew Jackson. A century later, the LHA would complete an "award winning restoration" of the complex from 1989 to 1997, which shows participation in the third preservation movement discussed below.

Another group of eighteen women "frustrated by their exclusion from men's organizations," established Daughters of the American Revolution in 1890 and their first memorial was dedicated to George Washington's mother, Mary, another nod to the early MVLA. ${ }^{15}$ Today the DAR still promotes a patriotic vision, but supposedly through the lens of diversity, and encourages an "enlightened public opinion" through education. However, it remains to be seen whether those ideas are being implemented outside of their own exclusive membership to the larger national public. ${ }^{16}$ Daughters of the American Revolution maintains historic sites in all fifty states, with three house museums in Oregon: the Robert Newell House Complex and the Pioneer Mother's Cabin in St. Paul and the Caples House Museum Complex in Columbia City.

\footnotetext{
${ }^{13}$ Andrew Hurley, Beyond Preservation: Using Public History to Revitalize Inner Cities (Philadelphia: Temple University Press, 2010), 3.

${ }^{14}$ Harris, New Solutions, 9

15 “DAR History," Daughters of the American Revolution, Accessed 2021. Link: https://www.dar.org/national-society/about-dar/dar-history

16 "DAR History," Daughters of the American Revolution, Accessed 2021. Link: https://www.dar.org/national-society/about-dar/dar-history.
} 
Most heritage organizations rose from the first preservation movement and wanted to "emulate" the type of formation, goals, and standards of the Mount Vernon Ladies Association. ${ }^{17}$ Their early preservation work shows how key collaboration was at this early juncture, despite the limitations of inequality in race, class and gender that were clearly prevalent. The culinary arts, blacksmithing, architectural construction, and colonial landscaping, among many other topics, are research interests inspired by interpretive actions at Mount Vernon over the decades. Modern archeological and historical investigations have also unfolded discussions about how to address and respect difficult subjects, such as the early lifeways and struggles of formerly enslaved African Americans.

In From Storefront to Monument: Tracing the Public History of the Black Museum Movement, historian Andrea Burns says that African Americans also had an important early role in heritage preservation, especially in urban areas after the Civil War, by establishing "churches, benevolent associations, and improvement and literary societies." ${ }^{18}$ In 1895, Booker T. Washington fought to include African American history and culture in the Cotton States International Exposition in Atlanta, Georgia. It was a strategic move to showcase Black culture from their own perspective with exhibits produced by their own creativity, which criticized and "challenged the dominant cultural representations" presented by white-run museums and organizations. ${ }^{19}$

\footnotetext{
${ }^{17}$ Barbara Howe, "Women in Historic Preservation: The Legacy of Ann Pamela Cunningham," The Public Historian, Vol. 12. No. 1 (Winter 1990, pp. 31-61), 35.

${ }^{18}$ Andrea Burns, From Storefront to Monument: Tracing the Public History of the Black Museum Movement, (Amherst: University of Massachusetts Press, 2013), 7.

${ }^{19}$ Burns, 8 .
} 
Between 1895 and 1910, the number of colonial historic homes being preserved rose to over one hundred and the government and the Smithsonian Institution began to preserve battlefields and conduct "ethnographic and archaeological research" at many types of historic sites. ${ }^{20}$ However, an "elitist social and cultural agenda" continued to shape interpretation in the growing number of house museums. ${ }^{21}$ Antique homes became "commemorative shrines dedicated to war and politics" because prominent white historical groups had control over what collections and narratives would be presented, which generally excluded women and almost always minorities. ${ }^{22}$ Preserving famous historic mansions was done to commemorate architecture and power, ensuring that the "dead rich white guys" who built them were heroized and the narrative contributed to the construction of national myth. ${ }^{23}$ As the fields of history and preservation became "an increasingly professionalized masculine arena," the crucial roles of women and minorities were further marginalized and/or ignored.$^{24}$ By the 1890 s, white male scholars had taken on a "scientific stance based on archives and critical analysis," which came to dominate the goals of museums and universities, from which many groups were excluded. ${ }^{25}$

Intellectuals like W.E.B. DuBois and Carter G. Woodson pushed back against the deliberate whitening of "collective memory" through vindication narratives, which

\footnotetext{
${ }^{20}$ Thomas King, Cultural Resource Laws \& Practice, Fourth Edition (New York: AltaMira Press, 2013), 16.

${ }^{21}$ Hurley, 5 .

${ }^{22}$ Harris, 7.

${ }^{23}$ Harris, 9 .

${ }^{24}$ Page, 9.

${ }^{25}$ Ashton, 146.
} 
asserted that African Americans were worthy of respect and representation. ${ }^{26}$ The preservation of Cedar Mill, the home of Frederick Douglass in Washington D.C., is a good example of this fight. After Douglass passed in 1895 his second wife and widow, Helen Pitts Douglass, began a memorial association in his name and a relationship with the National Association of Colored Women (NACW) to save the house and property. After her own passing, the home was transferred from the Frederick Douglass Memorial and Historical Association to the NACW in 1916, and the group was able to fundraise and pay off the mortgage in only two years. Black clubwomen of the NACW wanted to honor Douglass "through preservation of his domestic space, rather than a statue bearing his likeness," a place that would symbolize African American accomplishments, as well as family life. ${ }^{27}$ Historian Joan Johnson notes that, despite the intersectional challenges black women faced at this time, successful fundraising on the part of the NACW was really "not surprising considering the long tradition" of female philanthropy in the United States. $^{28}$

The idea of creating cultural resource protection laws for historic properties began to build momentum after the turn of the twentieth century as well. The Antiquities Act and the Historic Sites Act were both measures that allowed for continued expansion of historic sites. They also encouraged the organization of societies and districts in the decades leading up to World War II. The two laws became templates for later

\footnotetext{
${ }^{26}$ Burns, 9.

27 Johnson, Joan Marie, “'Ye Gave Them a Stone:' African American Women's Clubs, the Frederick Douglass Home and the Black Mammy Monument", Journal of Women's History, Vol. 17. No.1 (2005), 68.

28 Johnson, 66.
} 
preservation legislation and were important to creation of house museums because historic buildings and objects were included in their descriptions. However, they did not afford the expanded protections that later statutes would.

The Antiquities Act of 1906 provided the "first historic preservation legislation" and paved the way for the beginnings of federal survey work and identification of sites and later new bills and national trusts. ${ }^{29}$ President Theodore Roosevelt signed the act into law to protect archeological sites on federal lands, which were "vulnerable to looting, vandalism, commercial development and other permanent changes." ${ }^{30}$ The language of the act included identification and protection of "historic landmarks, historic and prehistoric structures, and other objects of historic or scientific interest." 31 This broad definition opened up conversations about the types and sizes of sites and monuments that could be designated by the President, which included historic homes. A few recent scholars however have argued that the Antiquities Act "did little or nothing to control the damage" already done to historic properties throughout the country, by way of things like neglect and vandalism, and that the President can have too much authority to designate, reduce or abolish federal monuments. ${ }^{32}$

After the Antiquities Act began to make an impact, a wider growth of historically related institutions and federal jobs pushed the first preservation movement forward at a slow and steady pace. The creation of the National Parks Service (NPS) by Congress and

\footnotetext{
${ }^{29}$ Tyler, 42.

${ }^{30}$ Congressional Research Service, National Monuments and the Antiquities Act, CRS Report: Prepared for Members and Committees of Congress, Updated November 30, 2018 (Pg. 2).

${ }^{31}$ Tyler, 42.

${ }^{32}$ Page, 128.
} 
Woodrow Wilson in 1916 aimed to conserve natural areas and wildlife, historic places, and objects, and now employs staff taking care of over eight million acres of property. The Thomas Jefferson Foundation organized in 1923 as a private nonprofit and put Monticello on the map, which is now second only to Mount Vernon in visitorship and has also undergone "major restoration projects" in recent years. ${ }^{33}$ Andrew Hurley also notes the importance of the 1920s for the creation of the first historic districts in Charleston, South Carolina, and Williamsburg, Virginia. Economic preservation was one of the main "tactics and tools" of saving heritage sites at this time, a way of using historic places to promote tourism and business. ${ }^{34}$ While the focus was still on honoring the "glorious colonial past" when saving historic structures, a new goal of early preservationists was countering destructive development. ${ }^{35}$

New Deal programs produced by Franklin D. Roosevelt's administration during the Depression provided infrastructure and jobs, but two of them specifically expanded the field of historic house museums: the 1933 Historic American Buildings Survey (HABS) and the 1935 Historic Sites Act. The former was a relief program for architects and university interns, who conducted summer surveys and collected photos and historic data on antique buildings. Information added to the HABS database includes everything from the "the smallest utilitarian structures to the largest and most monumental," and the program now provides access to the public online, through collaboration between the

\footnotetext{
33 “Thomas Jefferson Foundation Overview,” Monticello website, https://www.monticello.org/thomasjefferson-foundation/thomas-jefferson-foundation-an-overview/

${ }^{34}$ Hurley, 5.

${ }^{35}$ Hurley, 4.
} 
National Park Service, Library of Congress and private property owners. ${ }^{36}$ Since its inception, forty thousand sites and three other programs have been added covering engineering, landscaping, and mapping, which taken together builds a "complete picture of the culture of the times" for every site possible. ${ }^{37}$

The Historic Sites Act of 1935 allowed for preservation of "historic sites, buildings, and objects," seemingly an open-ended definition, but focused only on places of "national significance" and limited the ability to include a diverse spectrum of sites ${ }^{38}$ However despite the contradictory goals, the bill was a key precursor to later legislation of the second preservation movement discussed below. It also established a special class of sites called National Historic Landmarks (NHL), created an NPS Advisory Board to evaluate designation and/or additions of them, and made a substantial effort at surveying until the beginning of World War II. However, the Historic Sites Act prioritized architectural significance over people and lifeways, and set designation of sites to pre-1870, which was a controversial standard that had to be later "reaffirmed and codified" by the National Parks Advisory board. ${ }^{39}$ The Secretary of the Interior was authorized to "survey... acquire, restore, maintain, and manage" sites, which benefitted national

\footnotetext{
${ }^{36}$ Tyler, 47.

${ }^{37}$ Tyler, 48. Note: The three other programs include the Historic American Engineering Record in 1969, the Cultural Resources Geographic Information Systems in 1989, and the Historic American Landscape Survey in 2000. While no expert on these partnered databases, it might be interesting to note that a merger of all could create a more efficient and complete record, get rid of extraneous or duplicate data and make for a better recording system into the digitized future.

${ }^{38}$ Tyler, 50.

${ }^{39}$ Page, 120.
} 
preservation, but did not protect privately owned properties from destruction, especially by the government itself. ${ }^{40}$

The demolition of Penn Station in New York in 1963 sparked the second major movement in historic preservation in the United States. Even though the famous train station was already in disrepair and losing money, its destruction and replacement by mediocre construction represented a lack of respect by "a city disdainful of its gloried architectural past," a mistake other urban areas did not want to repeat in the future. ${ }^{41}$ Heritage activism that grew from the loss of Penn Station inspired the creation of the National Historic Preservation Act (NHPA) of 1966, which established the National Register of Historic Places. The legislation represented an explosion of renewed support for historic preservation and the Section 106 evaluative process was created for projects occurring on federal properties. State historic preservation officers were appointed to represent heritage interests, consult on federally funded and/or permitted projects, and follow specific criteria for assessing National Register significance and integrity. ${ }^{42}$ The act also created a program to create and recognize Certified Local Governments, which would have heritage review boards that provide education, resources, and occasional funding to support surveys and inventories.

The textbook Historic Preservation by Norman Tyler provides a thorough description of the NHPA, with a clear overview of what the law covers, the roles of state agencies,

\footnotetext{
${ }^{40}$ Oscar S. Gray, "The Response of Federal Legislation to Historic Preservation." Law and Contemporary Problems, Vol. 36, no. 3 (1971): 314-28. Accessed April 6, 2021. doi:10.2307/1191055.

${ }^{41}$ Michael Kimmelman, "When the Old Penn Station was Demolished, New York Lost its Faith: Today's version is humiliating and bewildering," New York Times, April 24, 2019 (Accessed 04/01/2021). Link: https://www.nytimes.com/2019/04/24/nyregion/old-penn-station-pictures-new-york.html

42 Harris, 7
} 
the importance of historic significance for successful designation, several legal case studies, lessons on architectural styles and other important information. The law asserts that the "spirit and direction of the nation are reflected in its historic heritage," that those irreplaceable foundations are being lost and must be preserved together with inevitable urban development. ${ }^{43}$ The main goal of the act and the register is to "expand and maintain" a list of resources, increase knowledge, and to create better means of identifying, preserving and administering sites ${ }^{44}$ The legislation has more than "proved its worth," according to Norman Tyler, and saved many historic homes and sites slated for destruction otherwise. ${ }^{45}$

However, there is great debate about urban revitalization and renewal projects causing gentrification of cities, through displacement and marginalization. Critics have said that corporate developers used the NPHA as an excuse to remove targeted ethnic populations and knock down inner city neighborhoods, to construct restricted buildings, freeways, and sports coliseums, all in the name of urban revitalization. Norman Tyler's preservation textbook had an apathetic stance, not denying that gentrification was a result, but defending that the consequences "could not have been anticipated by its creators" when the NPHA was signed into law. ${ }^{46}$ Graduate student Charles Lawrence concluded that historic preservation today is a "far cry" from what it used to be when the legislation was enacted fifty-five years ago, and preservation offices now have more inclusive and broad

\footnotetext{
${ }^{43}$ National Historic Preservation Act, 54 U.S.C. $\S \S 300101-307108$, Section 1 (16 U.S.C 470), 1966.

${ }^{44}$ Page, 231

${ }^{45}$ Tyler, 72

${ }^{46}$ Hurley, 9
} 
approaches to significance and integrity. ${ }^{47}$ Lawrence confirms that it has taken decades to evolve and that work still needs to be done, but he advocates for a future where "heritage conservation and housing policy would be aligned" through new partnerships, public participation, and careful evaluation and planning. ${ }^{48}$

Whichever side scholars take about NPHA and whether it was directly responsible for gentrification, the fact is that displacement and modern development did occur, which had "disastrous consequences for the older residential areas fringing the central core" of cities across the nation. ${ }^{49}$ Blight was the common excuse for demolition of ethnic neighborhoods, rather than investing in physical, social, and economic restoration. Destruction of entire districts, supposedly due to decay or neglect, forced families and businesses that had been in those locations for generations to move. For developers, it was more profitable to tear down and start over than communicate with residents about what they wanted or imagine new ways to restore structures and incorporate historical elements that would provide for continuity of the past within each growing urban area. As gentrification began to affect neighborhoods across the United States, the rise of social history in the 1960s would redefine the "purposes and practices of historians," who started to focus on those groups that had been disenfranchised, and away from upper class prominence. ${ }^{50}$ The field of public history also professionalized in the 1970 s, with interest in uncovering the diverse perspectives of "ordinary people," a topic that would

\footnotetext{
${ }^{47}$ Charles William Lawrence, "New Neighbors in Old Neighborhoods: Explaining the Role of Heritage Conservation in Sociocultural Sustainability and Gentrification" (2010) Thesis (Historic Preservation). 75 http://repository.upenn.edu/hp theses/145

${ }^{48}$ Lawrence, 76.

${ }^{49}$ Hurley,

${ }^{50}$ Thomas Cauvin, Public History: A Textbook of Practice (New York: Taylor \& Francis, 2016), 7.
} 
become important for new oral histories, museum exhibits and programming, and university training. ${ }^{51}$ Staff and volunteers working in historic house museums started thinking about organizing collections and focusing on women and minority history in their narratives, which began to change the "overall conception and definition" of diverse subject matters and how they could be presented to the public. ${ }^{52}$

African American public historians made key contributions to changes during the 1960s by embracing “institutional capacity, self-sufficiency, and black pride," in order to interrupt and challenge traditional models. ${ }^{53}$ Historian Andrea Burns asserts that civil rights gave them a platform to move from "storefront beginnings into larger structures." 54 Knowing that white support would still be needed for a national museum, black leaders formed coalitions and alliances, and applied for grants to garner support all across the country. Local museums, including those in historic homes in African American communities and their grassroots applications, had already "set a precedent" that larger institutions could no longer ignore. ${ }^{55}$

Creating a national museum dedicated to African American history was a struggle and a debate arose about whether to place it in the National Mall or in a city more fitting to black independence and activism. Some leaders like Director of the International AfroAmerican Museum (IAAM) in Detroit, Dr. Charles Wright, argued that a federally funded site "removed control" from the black community in Washington D.C. ${ }^{56}$

\footnotetext{
${ }^{51}$ Cauvin, 7

52 Cauvin, 9

53 Burns, 156.

${ }^{54}$ Burns, 157.

${ }^{55}$ Burns, 158.

${ }^{56}$ Burns, 161.
} 
According to Wright, government agendas ignored African American agency and undermined neighborhood museums like the Frederick Douglass house, which had already been denied $\$ 50,000$ for restoration. ${ }^{57}$ Black historians and clubwomen of the NACW knew that the house would allow for incorporation of radical thought and new narratives, by negotiating an "alternative public identity for African Americans," based on Douglass' revered struggle for equality and respectability, as well as his everyday life, family, and larger circle. ${ }^{58}$

Two bills were introduced to Congress in 1965 and 1968 to create a commission to "research the feasibility" of a national museum site, at first failing under Representative James Scheuer (D-NY) and then passing under Congressman Clarence Brown Jr. (ROH). ${ }^{59}$ Three museums were built during this time, all with passionate leaders like Margaret Burroughs and Charles Wright directing their creation: the DuSable Museum in Chicago, IAAM in Detroit and the Anacostia Neighborhood Museum in Washington D.C. In terms of the Frederick Douglass home, the National Association of Colored Women had struggled to maintain the property since acquiring it in 1916, despite raising thousands of dollars over the years for maintenance and repairs and thought it best to turn the property over to the National Park Service in 1962. This was a motion spearheaded by their club president, Mary Burnett Talbert, who knew that the project "reflected on black

\footnotetext{
${ }^{57}$ Wilson, Mabel, Negro Building: Black Americans in the World of Fairs and Museums (University of California Press, 2012), 188.

58 Johnson, 63.

${ }^{59}$ Burns, 160.
} 
women" and their work to preserve the site over the decades and she wanted it to become a national landmark. ${ }^{60}$

Carter G. Woodson's property in Washington D.C. was another example of the importance of African American homes to the black history movement in the 1970s. Woodson created Negro History Week and was the founder of the Association for the Study of Negro Life and History (ASNLH), which was a center for research and mentorship, and a substantial repository for cultural collections and journal publication, all headquartered in his home. After he passed in 1950, the ASNLH used the home for another two decades, before the National Parks Service took over in 1971. The property was designated a National Historic Landmark five years later, despite being in a "state of disrepair." ${ }^{61}$ After receiving grant of $\$ 63,000$, the NPS finished restoring the house and opened to the public in 1983.

As the shifts in historical thinking increased during the 1980s and 1990s, preservationists and public historians presented brand new ideas about reinterpretation and adaptive reuse of historic homes. Their assertions about the state of the field inspired the third movement in heritage preservation. More diverse types of properties were being nominated for greater recognition, like the Frederick Douglass house becoming a National Historic Site in 1988. Preservationists also began to produce a broader range of research projects and feasibility studies, like the one conducted at Carter G. Woodson's home in the 1990s, which finally concluded in 2002 that the home was "indeed suitable

\footnotetext{
60 Johnson, 68.

${ }^{61}$ Pero Gaglo Dagbovie, “"Most Honorable Mention...Belongs to Washington D.C.:' The Carter G. Woodson Home and the Early Black History Movement in the Nation's Capital," The Journal of African American History, Vol. 96, No., pp. 295-324 (Summer 2011), 315.
} 
for designation." ${ }^{\prime 62}$ Heritage managers began to seriously reevaluate "the sustainability and relevance of our historic houses," whether there were too many, why the public was bored with them and how biases about race, class and gender could be addressed. ${ }^{63}$

Beginning in 1998, a large group of articles from the Forum Journal and History News, by experts like Richard Moe and Carol Stapp, acted as forerunners that inspired reflection and action for the third movement. The two heritage professionals questioned whether Americans were still interested in stewardship of those types of sites, arguing that staff and boards of house museums needed to totally "rethink and expand their purpose if they wish to remain viable." ${ }^{64}$ Professionals began to debate the profitability of heritage tourism and pushed for increased tax incentives because the "federal program grew stingier" each day. ${ }^{65}$ Scholarship "reflected recognition" that changes were needed to reinterpret sites to include diverse narratives and tackle hard topics, address challenges to physical preservation, and transition them into "repositories of shared memories" rather than moments frozen in time. ${ }^{66}$

This third movement led to limited millennial legislation, such as the Save America's Treasures Program of 1999, which aimed to provide grant opportunities and matching programs through collaborations between the National Parks Service and private sector. That program was a response to the need for more support on a higher federal level, but grassroots organizations and private owners still needed help to find increase funding and

\footnotetext{
${ }^{62}$ Dagbovie, 315

${ }^{63}$ Turino, 277.

${ }^{64}$ Richard Moe, “Are There Too Many House Museums?” Forum Journal (Vol. 27, Number 1, Fall 2012), 55 .

${ }^{65}$ Hurley, 16.

${ }^{66}$ Hurley, 19 \& 25.
} 
reinterest their communities. The Carter G. Woodson House was also finally designated as a National Historic Site in 2006 and staff from the Frederick Douglass National Historic Site now manage both interpretive properties.

Designation of the Woodson home came with expectations for full restoration, development of exhibits, research, and management and there is also close association and consultation with the Association for the Study of African American Life and History, as well as the Organization of American Historians. Along with the NPS, the three organizations play "key roles in the movement to restore and memorialize" the Woodson home. ${ }^{67}$ At the tail end of the third preservation movement in 2011, the National Treasures Program acknowledged the endangered nature of historic sites and hoped to provide "potential solutions to the threats they faced." 68 Their mission under the National Trust for Historic Preservation aims to raise funds, prevent demolition, fight legal cases and "reflect our past while enriching our future." 69

The three movements above represent how preservation was first activated and organized, put into legislation, and then challenged by scholars and professionals to rethink old paradigms. The first movement from 1850 to 1950 is the longest and is notable for inspirational female philanthropy, early legislation, organization of historical societies and creation of historic districts. The second movement provided key legislation that would be followed and utilized to modern day. The third movement began contemporary debates about gentrification and social justice, sustainability and relevance,

\footnotetext{
${ }^{67}$ Dagbovie, 321.

68 Tyler, 65

69 "National Treasures: Our nation's historic places reveal the richness of the American Story," (National Trust for Historic Preservation, Accessed Fall 2020). Link: https://savingplaces.org/national-treasures
} 
and the need for new methods of planning, interpretation, and public engagement. Today, the current movement (discussed below) is a time of experimentation and implementation of innovative ideas related to those topics, along with digitization and social media utilization. Major shifts are in progress, within public history policy and practice, to invite input from all types of stakeholders and plan projects with respect to diversity, equity, and inclusion.

\section{Scholarship on the Fourth (Current) Preservation Movement}

The female activism of the first movement left a legacy that allowed for saving both colonial heritage by white women, as well as the Frederick Douglass house by black clubwomen, which opposed the elite public identity and created a new alternative of American history. The first movement also birthed template laws that would inspire more comprehensive legislation and allowed for the beginnings of historical societies and urban districts. The second movement responded to the loss of sites due to urbanization and provided key federal law that allowed for protection and nomination based on eligibility. The NHPA created a governmental support system and standard of significance and has enabled the designation of thousands of new historic sites across the country over the last five decades. However, for many African Americans (and other cultural groups) development in the name of revitalization ended in gentrification and a great loss of connection to their shared cultural past. Preservationists and historians of the third movement considered the challenges to all types of house museums, both in federal 
policy and in professional practice. They learned that new legislation, reinterpretation and engaging public agency were the keys to the evolution of the field.

House museum professionals are currently participating in the fourth movement in historic preservation. They are lobbying for new bills, trying new property uses, creating programs that reach out to a greater range of community groups, preserving collections and designing exhibits that speak to continuity and common life. Inviting public opinion is key to investigating what topics local people desire to learn about and how they view their own place in the community, then using that information to interpret house museums that respect the past, present and future of that local culture. Board responsibilities are growing more complex and collaboration with multiple experts and organizations is now required for proper management. Funding is still competitive, but grassroots organizations and granting agencies are inventing new ways to make federal monies, awards, and local support available to a more diverse set of sites.

Several scholarly sources provided important new outlooks on historic house museums and give advice to current preservationists and historians participating the fourth movement. Their arguments (in chronological order of publication) were informative to finding out how professionals are revising old methodologies and tapping into public agency, as well as what ideas they have for the future of the field. Some make very strong arguments for total re-evaluation and alternative use, while others encourage boards, staff, and volunteers to simply "step back and focus on the processes... and scale them up or down" for each unique situation. ${ }^{70}$ The former view shows that experts are pushing for

\footnotetext{
${ }^{70}$ Turino, 3 .
} 
innovative and sometimes controversial approaches and solutions, while the latter view advocates for a more practical approach that attends to the varied spectrum of sites. All the sources prove that historic house museums are indeed interdisciplinary spaces and that any of their methods can be applied to a site, depending on the circumstances, level of need, availability of funding and abilities of staff and volunteers.

In 2007, New Solutions for House Museums: Ensuring the Long Term Preservation of America's Historic Houses by Donna Ann Harris provided a detailed look into how professionals were rethinking the field during the third movement and arguing for change. While this two part book is the oldest of sources discussed here, scholars still include Harris in contemporary discussion because of the unique alternatives she presented. A long time heritage executive and project manager, Harris was the first to say that people might be "horrified" at the options presented in her book, but it suggested new possibilities to those professionals questioning sustainability at that time. ${ }^{71}$ Sometimes the term sustainability itself can be misleading; it implies that something can be preserved and used forever, but in reality, it means meeting the needs of the historic site without compromising the needs of the living community, for as long as possible. Harris faced that fact and pressed that "museum use is not necessarily the best conclusion" for every historic house anymore. ${ }^{72}$

The author advocated for eight "new options and solutions" for historic house museums: donating to universities for study, reprogramming for mission based use, costewardship agreements, asset transfer and merger, long and short term leases, sale with

\footnotetext{
${ }^{71}$ Harris, 3

${ }^{72}$ Harris, 4.
} 
easements or to a non-profit, and government donation. ${ }^{73}$ These were not new methodologies, but alternatives that Harris asserted were being experimented with and could benefit other sites in the future. As a project manager, she acknowledges that boards are often forced to make difficult choices with little funding for both maintenance and programming, but in order to be a "preservation trailblazer," organizations will have to take immediate, assertive and sometimes risky actions. ${ }^{74}$ Harris notes that three factors affect change at historic house museums, "operational issues, preservation concerns, or financial pressure," which means that museum boards and staff need to use a detailed strategic planning process that takes small annual steps toward their overall goal. ${ }^{75}$ Making big changes or selling a property can be difficult and heart-breaking, but Harris assures board members that simply by acknowledging the need for transition they are "acting responsibility to their stewardship obligations." 76

The eight solutions presented by Harris can be unnerving to think about implementing, as most staff and volunteers do not want to give up their house museums for any reason, especially if they would no longer have access to the property or collections. However, if thinking about what is best for the sustainability of the structure and the community is more important today, than these ideas are still crucial for organizations to at least discuss as possibilities. Historic house museums are the "bedrock of the American preservation movement" and Harris rightly asserts that evolving from the old paradigms to a multifaceted approach is key to solving issues of funding and the decline of maintenance

\footnotetext{
${ }^{73}$ Harris, 3

${ }^{74}$ Harris, 5.

${ }^{75}$ Harris, 230.

${ }^{76}$ Harris, 27.
} 
and visitorship. ${ }^{77}$ As one of the first to provide answers to questions being asked by scholars in the early millennium about sustainability of house museums, it makes sense that her work is still used as a backbone resource for actively rethinking house museums today.

The Anarchist's Guide to Historic House Museums by Frank Vagnone and Deborah Ryan boldly declared in 2016 that staff in house museums "need to take bold steps to expand their overall purpose" by directly inviting community input and collaborating with other organizations and experts. ${ }^{78}$ The two professionals make a valid argument that new methodologies of re-evaluating properties will help house museums adapt to and "thrive in a rapidly changing world" and they question the old models of collections management and interpretation still prevalent at many sites. ${ }^{79}$ Rather than providing concrete solutions to run with as Donna Ann Harris did, the Anarchist authors wanted their research results to be a "point of departure" for house museums to embrace reevaluation. ${ }^{80}$

Vagnone and Ryan provide a methodology for house museums to continually reassess their individual sites over time. Their work is aimed at "transference" of experience, or working with the public to help them reconnect with feelings of their own past and then interpreting the home to allow for that bond to build and continue. ${ }^{81}$ The evaluative tool seems exciting at first, as it calls for "the holistic deconstruction... and re-establishment

\footnotetext{
77 Harris, 6.

${ }^{78}$ Frank D. Vagnone and Deborah Ryan, Anarchist's Guide to Historic House Museums: A GroundBreaking Manifesto (Left Coast Press: Walnut Creek, CA, 2016), 39.

${ }^{79}$ Vagnone, 46.

80 Vagnone, 46.

${ }^{81}$ Vagnone, 25.
} 
of a paradigm from the perspective of human habitation." ${ }^{82}$ In other words, the authors argue that staff and volunteers at each historic house museum can completely reinvent their narrative through a specific method of evaluation and reinterpretation, which brings the public inside that process, rather than leaving them outside to comment on it after the fact.

The Anarchist Chart tool is organized under five thematic categories of Community, Communication, Experience, Collections/Environment, and Shelter, with 160 evaluative questions for sites to answer. ${ }^{83}$ The methodology seems too complicated for popular implementation, but the book remains a good reference that contributes important advice and tips for evaluation of sites. The idea that house museums need to "change and evolve" to reflect current events and get in touch with diverse audiences, and to create methods that shape visitor experiences, resonates deeply and many ideas are tempting to try out on visitors. ${ }^{84}$ For example, the self-tour tagging system, where tour groups leave small notes about things they did and did not like about the home, the property, collections and exhibits, would be easy to implement and provide very useful information for reinterpretation planning at both of my case studies presented in this thesis.

The same year Vagnone and Ryan came out with their bold strategy, Max Page and Marla R. Miller published Bending the Future: Fifty Ideas for the Next Fifty Years of Historic Preservation. Written to recognize the fiftieth anniversary of the National Historic Preservation Act, the two university history professors asked a diverse group of

\footnotetext{
82 Vagnone, 41.

83 Vagnone, 41.

${ }^{84}$ Vagnone, 48.
} 
preservation professionals to "reconsider received wisdom" about policies and practices, to answer tough questions about sustainability of historic sites and structures, and to give advice on how to contribute to preservation activism. ${ }^{85}$ Authors in Bending the Future make "sparks fly" with a host of preservation related topics, such as sustainability, relevance and legal policy, methodology, culturally sensitive narratives and even environmental conservation. ${ }^{86}$ The varied opinions, sometimes in debate with one another, were informative in getting a more comprehensive view of what many different professionals are working on today.

Historic Preservation by Norman and Ilene Tyler, and co-author Ted Ligibel, is a recent examination of the field, especially the National Historic Preservation Act and its provisions. According to the authors, heritage movements have played a persistent grassroots role in saving historic homes and are "constantly being defined and redefined" with each new generation. ${ }^{87}$ Professionals that contributed to this 2018 textbook agree that the field is now in a moment of "full creative flower," where scholars are recognizing the significance and irreplaceable nature of historic properties and neighborhoods, the need for increased interdisciplinary collaboration and brand new processes, and the great benefits of developing historic districts and tax incentives ${ }^{88}$ Historic Preservation contributed a clear timeline of the four movements, including various acts and programs that have shaped each wave of preservation in the United States over the last one hundred and seventy years. The authors confirm that "entirely new scenarios" are sparking

\footnotetext{
${ }^{85}$ Page, 3.

${ }^{86}$ Page, 4

${ }^{87}$ Tyler, 6.

${ }^{88}$ Tyler, 10.
} 
conversations about how to sustain properties, reinterpret narratives and reinvigorate public support today. ${ }^{89}$ Methods of property preservation, interpretation and public engagement are changing through social justice work, trial and error, detailed analysis, and innovative tactics.

The most recent source on preservation comes from heritage managers Kenneth $\mathrm{C}$. Turino and Max A. Van Balgooy, who noted in Reimaging Historic House Museums that habituative sites are in transition and "the story of their reinvention is still being written," alluding to the movement in progress. ${ }^{90}$ The most practical manual referenced for this chapter, the two editors present a "road map" of ideas from a large group of house museum experts on how to understand and contribute to the recent most wave in saving heritage properties. ${ }^{91}$ They welcome "diverse perspectives" on the changes in the field and present five parts on organizational fundamentals, engaging audiences, reinterpreting narrative, tour and exhibit advice and a final look at the future."92 The authors confirm that "more and more sites have adapted to change so as to better engage their communities and become more sustainable." 93 Showing that historic house museums can evolve by opening their doors to new perspectives and allowing active community participation is crucial to making them viable sources of history, education, tourism and living use.

\footnotetext{
89 Tyler, 66.

90 Turino, 3.

91 Turino, 3.

92 Turino, 2-3.

93 Turino, 277.
} 
Fundamentals cover the importance of evaluation to the reinterpretation process, the key roles and responsibilities of house museum boards, and how to better utilize volunteer service and conduct a successful capital campaign. Reimagining also included a key statement on History Relevance, a national trend in 2018 to "change the common perception that history is nice, but not essential." 94 Museums and non-profits all over the country have participated in that ongoing crusade, including in Oregon. ${ }^{95}$ Four of the authors in Reimagining discuss change in house museums by way of audiences, who can help "rethink" how sites work, noting that in terms of visitorship, mission based performance is more important than financial. ${ }^{96}$ Opinion matters because the public chooses whether or not to keep house museums alive by "participating and engaging, donating and talking" about them with one another. ${ }^{97}$

Long term cultural and heritage preservation requires continued collaboration, a dynamic variety of living programs that inspire involvement, and a focus on quality and authenticity. ${ }^{98}$ Audiences wish to seek out numen or a feeling of sacredness about a site, with "controlled opportunities" that link individuals to their own pasts through touch, smell or manipulation of artifacts. ${ }^{99}$ To create the close connection that the public wants in a house museum, narrative must be rethought according to each site and its full history. New approaches are "pushing the boundaries of interpretation" by playing to ideas (rather

\footnotetext{
94 Turino, 101.

95 When working as former museum curator in Hillsboro, Oregon in 2018, our staff participated in the History Relevance campaign. The museum had a large poster printed with the slogan "History is Relevant." Staff took pictures in different places with the sign and posted them on social media.

96 Turino, 105.

97 Turino, 107.

98 Turino, 118-120.

99 Turino, 130
} 
than just objects) to connect the past to current contemporary issues. ${ }^{100}$ Careful reflection on race, ethnicity, and gender roles, "rigorous scholarship to support the interpretation" and recreating the guided tour to be a self-guided transformative experience are all crucial to reinventing historic sites today. ${ }^{101}$

The above history seems short compared to the "many facets of historic preservation" that have evolved over time, including the work of individual activists, the interdisciplinary nature of the field and all the legislation to protect natural places, battlefields, monuments, buildings, and other types of sites. ${ }^{102}$ While every historic site and/or landmark make an important contributions to connecting the public to history, it was prudent to only focus on those statutes that directly pertain to house museums for this chapter. Having a base of historical knowledge about heritage preservation is key to understanding how new projects are being planned and implemented at sites today, as well as what the major needs are for safeguarding them for future generations.

All the scholars of the current movement discussed above have contributed important insight into how to tackle the many challenges that arise in historic house museums and other types of heritage preservation. The goal should be to passionately continue riding the momentum of this movement forward and not allow it to subside, by rethinking not only physical sites and narratives, but professional practice and legal policy as well. Now that a history of preservation movements has provided context, the next section presents a framework for looking at case studies in Oregon by discussing current statistics, the

\footnotetext{
${ }^{100}$ Turino, 150

101 Turino, 151

102 Tyler, 1
} 
spectrum of historic homes and four factors that are affecting projects in this state right now.

\section{A Framework for Current Projects in Oregon}

The National Park Service (NPS) reports that there are more than ninety-five thousand historic properties currently listed on the National Register of Historic Places, which all together includes more than 1.4 million "individual resources." 103 The pace of identification and listing has gradually "quickened" since the NHPA was signed into law in 1966, but while numbers of historic homes and nominations have increased, maintenance of the register itself has slowed. ${ }^{104}$ The National Archives only holds register records up to 2012, which is a serious nine year lag in public reporting of sites at this point. ${ }^{105}$ That said, a lack of funding for increased staff in state preservation offices does not improve the situation, especially considering the sheer number of ongoing projects, nominations and controversies that need mediation at any given time in every state. Even further, the loss of revenue due to Covid-19 forced the Oregon State Historic Preservation Office to lay off four positions in 2020, which had an impact on speed and efficiency of projects.

According to Donna Harris, the American Association for State and Local History counted nine thousand historic house museums in the United States in $1999 .{ }^{106}$ The

\footnotetext{
${ }^{103}$ National Park Service, National Register Database and Research webpage, Link:https://www.nps.gov/subjects/nationalregister/database-research.htm ${ }^{104}$ Harris, 8.

${ }^{105}$ National Park Service, National Register Database and Research webpage, Link:https://www.nps.gov/subjects/nationalregister/database-research.htm

${ }^{106}$ Harris, 8
} 
National Council on Public History website reports about thirteen thousand historic house museums across the United States right now, a thirty percent increase over the last two decades. ${ }^{107}$ In Oregon, the State Historic Preservation Office reports 610 registered historic sites in Portland Metro alone, with about two thousand spread throughout thirtysix counties statewide. ${ }^{108}$ All that said, scholars agree that it is impossible to find an exact number of historic houses because so many are unlisted and/or privately owned and a recount has not even been attempted since 1999. Additionally, new projects to conduct cultural resource surveys are often dropped or ignored because they "inevitably would be outdated" the moment they are finished, as new sites are added and lost almost every day. $^{109}$

Here is the problem: those numbers include only the listed properties, and those encompass all types of structures. Without a new survey of sites, both nationally and statewide, there is no way to know an exact current number of working and eligible historic house museums, which keeps the field feeling confused. Updating the register may not seem important on the surface, but knowing how many historic house museums there are, plus those that are nominated and eligible, would be beneficial in determining a more equitable representation. It would help in quantifying and analyzing the state of the field, then being able to formulate plans on how to continue evolving, especially in terms of education and social justice. Moreover, there are thousands of structures, buildings,

\footnotetext{
${ }^{107}$ Andrea Burns, Resource or burden? Historic House museums confront the $21^{\text {st }}$ century (National Council on Public History website, January 13 2015). Link: https://ncph.org/history-at-work/resource-orburden/

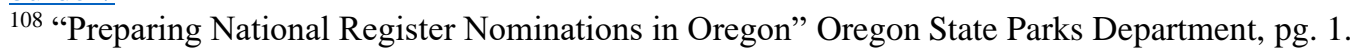
Link:https://www.oregon.gov/oprd/OH/Documents/08_18_NR\%20Handbook.pdf

${ }^{109}$ Harris, 8
} 
properties, main streets, and whole districts that still need major support, and possibly new or amended legislation, to accomplish protected status or simply to create interactional places that can connect to and educate their communities.

Historic house museums land on a wide spectrum of preservation, from the dilapidated, boarded up structure to the fully functioning interpretive site. In Oregon, there are many homes that clearly address "historical significance in virtually all of its tangible dimensions," from the indigenous longhouse to the emigrant cabin to the unique architectural styles of the Victorian and Edwardian eras, and even wartime military and migrant housing. ${ }^{110}$ That said, two thousand listed historic sites are only a fraction of what could be represented within every urban and rural district in Oregon. If staff at a site can understand where they are in terms of need and see models of similar house museums that have undergone reinterpretation, they can start to plan, experiment with, and implement changes that would improve their place in the community.

Determining where a house museum fits on a general spectrum shows how they may have been affected by preservation and stewardship over time, as well as what current needs are for reinterpretation and/or maintenance and repair. On one end of the spectrum, there are privately owned properties and century farms, run by descendants of emigrants who once chased the agrarian ideal, who have lived in their family homes for several generations, proudly maintaining them and opening to the public during harvest seasons. Visiting orchards and U-pick farms between June and October is a beloved pastime for native Oregonians and tourists alike. Some of the structures on these rural properties are

${ }^{110}$ Page, 145. 
beautifully kept and opened for occasional tours, while others continue to remain private and/or fall into disrepair. It all depends on each owner's level of knowledge, ability and care about heritage preservation and public education.

Next along the spectrum, there are small historic house museums that often have park district, private individual, or very small local historical board ownership, with very little interpretation or public access. However, new relationships are beginning to emerge between park districts and those private owners or groups, to gain awareness and support for restoration or rehabilitation of sites. However, one issue is that each park district is a separate entity, so there does not seem to be much communication or collaboration between them about projects, when the departments could be sharing information and resources, and getting more accomplished statewide. For many, it can be difficult to accomplish a full interpretive museum, despite having a solid vision, because a complicated list of needs creates barriers to implementation.

A medium house museum further along the spectrum represents a fully maintained and functional building, a good working board and even an engaged local member base. Often owned by county, state, or national historical societies (or even park districts), these sites mostly rely on the National Historic Preservation Act for eligibility and listing protection, provide annual events and fundraising for membership, and usually get regular local volunteer participation. As the Anarchist Guide authors asserted, both types of house museums described above are very often stuck in old paradigms, but all are ripe for reinterpretation and renewed public engagement. 
Large historic house museums at the opposite side of the spectrum should be working models for the rest, with full long term funding and influential board participation, community relationships and public popularity. If boards and staff do not keep up with social change and revisions to policy and practice though, they can be subject to great criticism by scholarship and the public, and partnerships and funding can be lost. That said, several in Oregon are engaging in change by reinterpreting their sites and being representative of the diverse modern community, including broader perspectives and creating new programming, which has been inspiring to watch over the last several years. This simple spectrum helps stewards to recognize that "historic homes are all different," with diverse family stories, styles of architecture and cultural communities. ${ }^{111}$ They are dynamic and fluid spaces where the level of need can change at any time, which is one reason why a dedication to sustainability and reinterpretation have become so important today. The goal is not to necessarily become huge profitable attractions, but to build a living place in their own neighborhoods, where preservation is continually supported, and the site is actively used for as long as possible. The two case studies in following chapters represent sites in the middle of the spectrum, one small ranch house in a public park and one medium sized historic house museum. The point here is to say that historic homes, in every area of the spectrum described above, need to undergo reinterpretation to create more functional and educational spaces for public engagement.

Innumerable positive and negative factors come into play when preserving and interpreting historic house museums. How those factors are prioritized depends on

\footnotetext{
111 Turino, 3.
} 
current strategic plans for each unique site. The importance of all ingredients functioning well (separately and together) is crucial to having a thriving house museum, for if one part breaks down, historic ground could literally and figuratively be lost. Indeed, the Anarchist authors commented that in their research, many of the "seemingly isolated problems began to appear interconnected" which is also common in historic house museums in Oregon. ${ }^{12}$ While this thesis does not comprehensively address all possible factors, those that are relevant to the field today can generally be included under the following four headings: methodology, public access and engagement, board capacity, and funding.

\section{Methodology in Historic House Museums}

Methodology refers to a full reworking of an historic home site, which includes reevaluating the property, designing a strategic plan for overhaul, and implementing changes, while asking for public comment and support every step of the way. The sheer variety of types and levels of preservation makes finding a standard methodology for reinterpretation next to impossible, as each site has a different story, collection and set of demands for maintenance. Flexibility is crucial in determining solutions because plans can easily and often change, to accommodate funding, organizational cooperation, and public input. History and preservation professionals now create, test, and expand new solutions and publish results, providing house museum staff a base of work to reference in determining what might work for their own place. ${ }^{113}$ Organizations must be able to

\footnotetext{
${ }^{112}$ Vagnone, 19.

113 Vagnone, 25.
} 
evaluate each structure and prioritize needs, but the process can feel like a revolving door, looking over a site and determining what needs to be done, then hitting numerous challenges, then reevaluating and making new decisions. Nonetheless, it is important not to skips steps if one is to be successful.

Turino and Balgooy recommend that historic house museums should "start small, experiment and evaluate" using their book as a blueprint for rethinking strategies along the way. ${ }^{114}$ Analysis is much more useful when grounded in income, grants, membership, and "data and criteria rather than anecdote and opinion." 115 Impact and sustainability "should shape and guide decisions" and public programs and activities should be carefully considered within that process. ${ }^{116}$ In Oregon, this is especially true for sites in the middle of the spectrum, which need to accomplish a diverse list of tasks from easy repairs to full restoration and staging.

The evaluative methodology of the Anarchist Guide is also commendable, but the process is too difficult to implement without significant training and support for staff, from the authors themselves. The guide is geared more for finished sites that do not need to start from scratch, but who are already at a point where they can rewrite strategic plans, create more inclusive narratives, and engage the public. It does not help the places that have potential to be house museums, but have little maintenance, organization, or funding.

\footnotetext{
114 Turino, 4.

115 Turino, 11.

116 Turino, 11-12.
} 
Alternative solutions presented by Donna Harris provide more unique challenges than other authors suggested, but many are entirely possible in Oregon, such as university study houses, co-stewardship, and reprogramming. The opportunity for student fieldwork is less than it ought to be in this state, but both case studies discussed in following chapters addressed this need through university internships. Co-stewardship has benefitted the case study represented in the third chapter and reprogramming is an idea that needs to be addressed at all sites along the spectrum, to ensure strategic plans are created that focus on "new missions and vision statements."117

One very important specific aspect of the methodology of reinterpretation, which needs discussion, is researching and rethinking narratives, or how a property fits into the local and national story. As noted above, reinterpretation encompasses many steps, but this part of the process to reevaluate historic house museums is crucial to the future of the field. In 1997, the Bosco-Milligan Foundation published a great document called Cornerstones of the Community: Buildings of Portland's African American History, which identified and documented 1,284 buildings "associated with African American individuals, institutions and events throughout Portland's history." ${ }^{118}$ Despite racial covenants that restricted sale or occupancy to many properties and neighborhoods, home

\footnotetext{
${ }^{117}$ Harris, 109.

118 Bosco-Milligan Foundation, Issuing Body, and Oregon. State Historic Preservation Office, Sponsoring Body. Cornerstones of Community: Buildings of Portland's African American History. Revised \& Expanded. ed. Portland, OR: Bosco-Milligan Foundation, 1997
} 
ownership became the most "consistent theme and objective of African American community life in Portland" in the first half of the twentieth century. ${ }^{119}$

A great example of that story in Oregon is the 1895 Martin Mayo House, a Queen Anne style in the Eliot neighborhood in Portland, which reveals many of the problems of race, class and land politics that are ingrained throughout state history. It is a privately owned home that fits in the smaller house museum area of the spectrum, discussed above, because there is a partnership to support the creation of a fully interpreted site. In January of 2019, I met with local artists and community activists Cleo and Kayin Davis, who had taken ownership of the property, which is still empty, boarded and perched up on support beams, and had been moved in that area twice before due to development. This time, the couple repositioned the Mayo home onto a new foundation at its current location on Sacramento Street, after negotiations with the city to wave $\$ 40,000$ in moving fees. The Eliot neighborhood and property itself were both direct victims of blight policy and the parcel once belonged to Cleo Davis' grandmother. She had owned an apartment building there in the 1980s and applied to the city for repair permits, which were denied. That building was demolished because repairs could not be done, and the Davis family lived in a small house on the back of the property for many years.

Cleo and Kayin Davis see an important opportunity to preserve the historic Martin Mayo House and create a community space in the original neighborhood, plus acknowledge the history of blight and how it greatly impacted African American families

\footnotetext{
${ }^{119}$ Bosco-Milligan Foundation, Issuing Body, and Oregon. State Historic Preservation Office, Sponsoring Body. Cornerstones of Community: Buildings of Portland's African American History. Revised \& Expanded. ed. Portland, OR: Bosco-Milligan Foundation, 1997 (pg. 54)
} 
and development in Portland. They are currently working with Restore Oregon to garner support and funding to rehabilitate the home and eventually create an "Art-chive" dedicated to African American art, history, and culture in Portland. Creating a cultural center in this neighborhood will uplift its local and national story, by telling a new counter history about African Americans in this state. It will also connect the original Austrian immigrant who built the home to the three physical structural moves due to development and blight, and then to black culture in Portland, which has been largely ignored until recent years. This example shows how important it is to discover the entire history of a property from beginning to the present, not only to honor the continuity of that place, but to make prudent decisions about its educational and community role in the future. It is also an interesting and refreshing change of practice, from the early perspective to segregate and group history, into picturing a broader shared past and dynamic social change over time.

\section{$\underline{\text { Public Access and Engagement in Historic House Museums }}$}

Connection with visitors has been at the "bottom of the barrel" of priorities in the past but inviting the community into decision making processes is now at the forefront of public history and preservation goals. ${ }^{120}$ Public access means not only having a site open to the public regularly, but a better availability of historical information by way of rotating exhibits, physical archives, online repositories, videos, learning activities and other mediums. It refers not only to people physically coming to the house and looking at

\footnotetext{
${ }^{120}$ Vagnone, 19.
} 
artifacts, but also providing as much information as possible about the house, family, community, and nation over time. Teaching about social change should be the main goal of all American house museums, providing any opportunity for visitors to think about, question and reevaluate their own biases about the past, as well as the people that make up their modern communities. That is the goal of the Martin Mayo house project discussed above, but they currently lack the funding for restoration to give the public the physical and informational access they need.

Public engagement refers to the need for historic house museums to employ the agency of community members in active reinterpretation projects, accessing contemporary voices and perspectives to find out how the past should be presented. Connecting with the public can be the most perplexing factor affecting house museums today because many staff and volunteers are simply not sure what to do, other than their regular holiday events, tours, and new exhibit openings, or how to find new stories to tell. However, change cannot come without taking risks and it is important for all organizations to try new evaluations of their sites, research new narratives and implement ideas and programs that might bring renewed interest and support.

Nina Simon's The Participatory Museum states that the reason visitorship to museums and historic sites has decreased is that people want to be "cultural participants, not passive consumers," able to interact, construct their own meaning and add their own voice. ${ }^{121}$ Boards and staff must accept responsibility for traditional messaging and loss of purpose in the community, and change their goals and values to include contemporary

${ }^{121}$ Nina Simon, The Participatory Museum,(Santa Cruz: Museum 2.0, 2010). Link: http://www.participatorymuseum.org/preface/ 
thought and contribute to positive social change. If they make public access and engagement top priorities for strategic missions and work outside in the community to find out what is important, the door to a new world of unseen opportunities will swing open and the public will feel welcome and inspired to bring their family and friends back time and again.

\section{Board Capacity in Historic House Museums}

Board capacity is the ability of an historic house museum organization to acknowledge issues and face challenges successfully, to collaborate with outside organizations and use their unique experience and skills to engage the public, regularly fundraise and adapt to changes in historical thought and strategy. According to museum administrator and financial manager Rebekah Beaulieu, a working board must have community members that can "offer professional insights" and be able to collaborate on fundraising activities and public programming. ${ }^{122}$ If a board cannot properly function in the above areas and be flexible to change, projects will wait in the wings or simply fail all together.

Financial Fundamentals for Historic House Museums addresses what boards should do to develop collective understanding and efficient decision making. Initial structural organization needs to include "legal incorporation, tax exemption, and historic designation." 123 Income and donor engagement should come with an understanding of the potential base and be able to develop an "effective system" of tactical solicitation and

\footnotetext{
122 Rebekah Beaulieu, Financial Fundamentals for Historic House Museums (Rowman \& Littlefield: Lanham, Maryland, 2017), 35.

${ }^{123}$ Beaulieu, 155.
} 
processing of gifts. ${ }^{124}$ Earning sustainable revenue must be based on "audience evaluation" and available resources, and boards must carefully track finances, and provide oversight and forecasting through regular statements of activity, position and cash flow. The latter means watching the numbers or tracking annual visitors, donor, and fundraising event contributions, using an efficient monthly budgeting system to stay on balance and saving for repairs and maintenance.

There can be high stakes for the board of an historic house museum, depending on where they sit on the spectrum. For those in the middle of the spectrum, fostering partnerships and applying for grants is important to beginning long term work. Smaller boards have a little more leeway in terms of professionalized practice, but still need to maintain the property and follow legalities. If a board does not have enough skills or knowledge level to be successful, they must increase networking with larger organizations, the state preservation office, and professional experts to get instruction and advice. For those historic house museums with greater support, there are expectations for a certain level of excellence and adherence to standards. This is when a larger board can run into problems if projects are ignored, money is mismanaged, or programming does not reflect how the public wants to engage. However, many boards in Oregon are recognizing the need to not only be there on paper, but actively participate on site, with staff and volunteers and of course, with visitors to ensure the continual sustainability of the property.

${ }^{124}$ Beaulieu, 156. 


\section{Funding in Historic House Museums}

Finding the money to fund or reinterpret a site is often the most frustrating factor for house museum organizations. The ultimate dream is to get that one big donation or grant that will save the house, landscape the property, and create a museum, while also providing for maintenance, management, curation, and programming in perpetuity. Would that be amazing! Unfortunately, most boards and staff now realize that permanent funding is usually impossible, and priorities are shifting to focus on practical methods for doing smaller projects more often, which will still have noticeable results. Prominent historic homes are often successful at acquiring large grants, endowments, and trusts, but funders are less likely to support a smaller farm or urban house, especially if they cannot envision the potential. For the vast majority, it takes continual work across generations to maintain local relationships and care for a house museum through donations and grants.

Beaulieu notes that "financial management is rhythmic," meaning that a new cycle begins each year that informs how to determine programmatic income goals for the next. ${ }^{125}$ Devising strategies for increasing revenue takes "investment in planning and evaluation," a strong mission and public message, and mindful management. ${ }^{126}$ If a house museum needs major structural or organizational work, larger grants and donations are sometimes available, but they are also the most difficult to secure. Grant writing is the one of the most important annual tasks for all house museum boards and directors, but it can be challenging to complete because of the work that goes into research and the very specific requirements for proposals to be competitive. In this state, the Oregon Museums

${ }^{125}$ Beaulieu, 157.
${ }^{126}$ Beaulieu, 157. 
Grant is one of these popular awards, which gives up to eight thousand dollars per year for projects that "collect, preserve, interpret, and promote the collective history" of the state. $^{127}$

Both case studies in the following chapters have gone through individual funding issues in the past, but today their boards and staff have faced them through application of grants, partnerships, and local support. While there have been clear lulls in repairs and maintenance and a lack of collections care in the past, organizations are now thinking about how to update care standards, and increase access and engagement, to bring in more revenue. Board members, staff and volunteers are attending grant workshops, travelling to preservation conferences, contacting experts in the field, utilizing interns, and other actions that can help them find funding and accomplish goals. Organizations should also be sharing at least basic financial information with one another, to find out what programs may bring increased visitorship, financial support and sustainability.

\section{Conclusion}

This chapter outlined the history of four movements in preservation of historic sites. The first movement began with early philanthropy and ended with the first legislation and urban districts. The second preservation movement represents a major legal statute that changed the face of preservation on a national scale, but also may have promoted systematic gentrification. Facing those issues and rethinking the sustainability of the

\footnotetext{
${ }^{127}$ Oregon State Historic Preservation Office, Oregon Museum Grant Information, 2020. Link: https://www.oregon.gov/oprd/OH/Documents/MuseumGrantInformation2020.pdf
} 
entire field motivated the third preservation movement. Scholarship on the current fourth movement proves that professionals are applying the lessons of earlier eras to new methodologies and finding different ways to connect to the public.

Four main factors affect current projects in Oregon: methodology, public access and engagement, board capacity and funding. I determined those factors not only from historiographical study, but through physical fieldwork and site visits conducted in three counties, and many interactions with guests, professionals and volunteers. The framework is used to analyze and discuss case studies in the next two chapters. The Stevens Crawford Heritage House in Oregon City is owned by a historical society and undergoing reinterpretation since 2018 . The second case study in the third chapter is the Hollinshead-Matson Historic House and Tack Shed, with a partnership being utilized to accomplish collections work and restaging since 2019. The epilogue of this thesis offers arguments for reinterpretation according to the framework outlined above, final thoughts on the two case studies and makes recommendations for the future of the field. 


\section{Chapter Two}

\section{The Stevens-Crawford Heritage House}

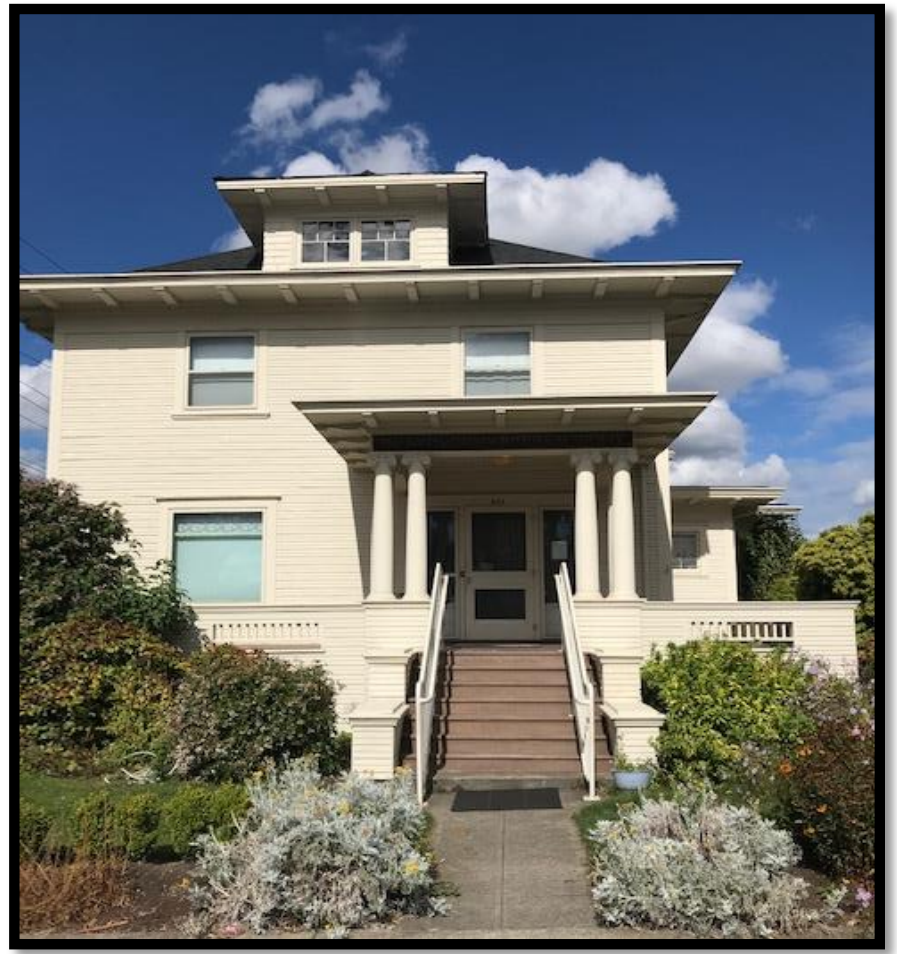

Figure 1: Liza Schade, iPhone image of the Stevens-Crawford Heritage House, Oregon City, Oregon. Taken by Spring 2019.
The Stevens-Crawford Heritage House (SCHH) is a beautifully maintained house museum located on the corner of Sixth Street, in the historic McLoughlin District of Oregon City, Oregon. The Clackamas County Historical Society (CCHS) owns and operates the home, along with their main building overlooking the Willamette Falls. The mission statement of the heritage house museum is to "preserve and protect the historic past of Oregon City, the Stevens family and their place in Clackamas County, for the enjoyment and education" of the public. ${ }^{128}$

In 2018, Johna Heintz, the Collections Manager of CCHS, in collaboration with Jenna Barganski, the Executive Director, proposed a new interpretive plan for the Stevens-

Crawford house to the society board. Since approved, main goals for the site have been to clean out collections, reimagine each room of the home as the family would have lived

\footnotetext{
128 Stevens Crawford Heritage House: Basic Guidelines for Docents, (SCHH File: Clackamas County Historical Society, Oregon City, Oregon, Fall 2020), 2.
} 
in the Progressive-Edwardian era and provide a more engaging and educational public space. This chapter describes historic preservation in the McLoughlin District and the transition of the Stevens-Crawford home into a museum, then discusses graduate fieldwork that I conducted with Johna Heintz as part of the current reinterpretation project. The last section analyzes the house museum according to the framework of four factors laid out in the first chapter and makes recommendations for the future of the site.

The Stevens Crawford Heritage House has great potential for long term sustainability because it is already a working museum with well-established society stewardship, and it is in a prime original location in a protected historic district. The Francis Ermatinger House and the old fire station are on the same block, which is just down the street from the famous John McLoughlin House. Even though the historic buildings in the district all have different ownership and vary in terms of agendas and engagement with the community, the opportunity for a major collaboration is ripe. A broad partnership between non-profit organizations and local businesses, along with a coalition working to create a heritage area near the falls, could make a positive difference for the future of the district and increase overall tourism for Oregon City. The Willamette Falls Landings and Heritage Area Coalition (WFLHAC) is helping to bring the larger community together to support national designation of a fifty-six river mile swath of land, from Oregon City south to Wheatland, Oregon. Clackamas County Historical Society, along with various other businesses and organizations, will be participating in this massive project to 
preserve "rich heritage, natural beauty, agriculture and recreational opportunities" for all to enjoy. ${ }^{129}$

However, before a long term expanded plan to connect with the larger community can be realized, there have been several challenges to work through. First, reinterpreting the Stevens-Crawford Heritage House has greatly improved the long term collections maintenance and exhibition of the property, but those are tasks that must always be reevaluated and reimplemented. Public access and engagement plummeted over 2020 because of the effects of Covid-19 on visitorship and a lack of revenue coming into the main museum over the falls. However, a virtual living history event will take place in June 2021 and a landscaping project later in the summer will provide opportunities for volunteers to help maintain the site. The board is committed to the sustainability of both the main museum and the historic house, but information about their current board capacity level is limited due to not being on the faculty. Museum funding in the pandemic was extremely difficult due to closures and the failure of the main heating, ventilation, and air cooling system that regulates the main building, which needed replacement. As the museum is not supported by the county, donations have been necessary to survive, but rental revenues should pick back up when vaccines allow businesses to fully reopen again.

129 “Our Coalition," Willamette Falls \& Landings Heritage Area Coalition, webpage, Accessed April 16, 2021.

Link: https://www.wflha.org/about/. 


\section{Preservation of Historic Homes in Oregon City}

The Stevens-Crawford Heritage House was built in 1908 for Mary Elizabeth

Crawford Stevens and her husband, Harley Stevens, in a new neighborhood above the Willamette Falls. While Portland developed into a major shipping hub, "growth continued, but at a slower, steady pace" in Oregon City, with industry shifting to manufacturing and residential construction moving further east and north of the falls. ${ }^{130}$ Congestion and industry around the turn of the century pushed residents to shift "from the city center to the second terrace" and families like the Stevens began to build homes on top of the basalt cliff above the falls. ${ }^{131} \mathrm{~A}$ courthouse and suspension bridge were constructed, paper mills dominated the lower town and the Willamette Falls Electric Company brought electricity and subsequently the East Side Railway, which made it possible to commute to Portland and further expand.

As the neighborhood began to grow around them, the McLoughlin Memorial Association decided to relocate John McLoughlin's original home to the top of the bluff in 1909, which became the "first major effort at historic preservation" in Oregon City. ${ }^{132}$ That famous home is now a protected landmark owned and operated by the National Parks Service, as a unit of Fort Vancouver. Further, in 1910 the Francis Ermatinger House was moved to the neighborhood and then Dr. Forbes Barclay's home was relocated adjacent to the McLoughlin House in 1937. Over the rest of the twentieth

\footnotetext{
130 Oregon City McLoughlin Conservation District 2002 Resurvey Final Report, Revised December 2003. (Historic Preservation Northwest: Prepared for the City of Oregon City), 5.

131 Oregon City McLoughlin Conservation District 2002 Resurvey Final Report, Revised December 2003 (Historic Preservation Northwest: Prepared for the City of Oregon City), 5.

132 Oregon City McLoughlin Conservation District 2002 Resurvey Final Report, revised December 2003 (Historic Preservation Northwest: Prepared for the City of Oregon City), 5.
} 
century, the residential neighborhood around the Stevens-Crawford house continued its urban growth to include a "large variety of vernacular homes, bungalows, post-1925 homes, non-historic homes and apartment buildings" along with several churches, schools, and a Carnegie Library. ${ }^{133}$

Individual owners in historic Oregon City began listing their properties after the National Historic Preservation Act was signed into law in 1966 and philanthropists like Ruth McBride Powers became "vital to historic preservation not only in Oregon City, but also in surrounding areas." ${ }^{134}$ Powers helped to save an entire list of historic homes in Oregon (including the Ermatinger House and the nearby John C. Ainsworth House) and was recognized for her larger efforts in 1974 by the National Trust, also receiving other awards and holding many civic affiliations. ${ }^{135}$ The first cultural resource survey in the Stevens-Crawford neighborhood was conducted from 1982 to 1986, which named 306 properties that were either listed or eligible for listing and determined the whole section on top of the bluff to be the Oregon City McLoughlin Conservation District. ${ }^{136}$ By 2003, a second cultural resource survey identified 802 historic resources, recorded "pertinent architectural and historical information" (including photos) about every property and determined that the entire McLoughlin District had sufficient integrity for inclusion in the

\footnotetext{
133 McLoughlin Conservation District, City of Oregon City website. Link: https://www.orcity.org/planning/mcloughlin-conservation-district.

134 Johna Heintz, Quote from edits for this thesis chapter. April 16, 2021.

${ }^{135}$ Her work would make an interesting, but unfortunately separate, thesis into the importance of women's roles in historic preservation in Oregon during the second movement.

136 Oregon City McLoughlin Conservation District 2002 Resurvey Final Report, Revised December 2003 (Historic Preservation Northwest: Prepared for the City of Oregon City), 1.
} 
National Register. ${ }^{137}$ Most recently in 2011, a survey that included the McLoughlin, Canemah and downtown districts identified a total of 1,750 listed and eligible properties throughout historic Oregon City. ${ }^{138}$ An increase of five hundred properties between the first and second surveys (over just two decades) is extensive for such a small district and proves involvement in the third wave of preservation discussed in the first chapter. ${ }^{139}$

How the Stevens-Crawford Heritage House Became a Museum

Mary Elizabeth Crawford Stevens had previously bought the property in 1890 but she and her husband, Harley Stevens, did not build the house until 1908. The couple hired Portland architect C.C. Robbins to design the building and contractor Charles Vonderay to build the home, but as pages are missing from the ledger now stored in the museum archive, the total price cannot be calculated. However, the records that are saved include building materials, payments, furniture, and floor coverings amounting to approximately five thousand dollars. Versions of the architect's original floor plans are still owned by the historical society as well.

Robbins followed the popular and practical craftsman style in American Foursquare form, which included a box shaped design, a hipped roof with center dormer, two main levels plus basement and attic, beveled leaded windows and a wrap-around porch with

\footnotetext{
137 Oregon City McLoughlin Conservation District 2002 Resurvey Final Report, Revised December 2003 (Historic Preservation Northwest: Prepared for the City of Oregon City), 1.

1382011 City-wide Historic Survey: An Oregon Heritage Excellence Winner, City of Oregon City. Link: https://www.orcity.org/planning/request-proposal-historic-survey-0.

${ }^{139}$ National Historic Preservation Act of 1966, as amended through 1992, National Register of Historic Places, Criteria for evaluation (36 CFR Part 60.4). Link: https://www.nps.gov/history/locallaw/nhpa1966.htm.
} 
scrolling Ionic style columns. The interior of the home has fine woodwork throughout, pocket doors between the main floor rooms and built-in cabinetry in the wall separating the dining room and pantry, creating a glass fronted storage and display accessed from both sides. A laundry chute could be accessed from the second floor linen closet to send clothing down to the basement and a lift was also installed to bring firewood up to the main and second floors. Amenities like a full kitchen, indoor plumbing and laundry, and gasolier light fixtures were very innovative in Oregon City during the early twentieth century. ${ }^{140}$

Mary Elizabeth Crawford was the daughter of emigrants Medorem Crawford and Adeline Brown, who had emigrated to Oregon in 1842 with the Elijah White party. Medorem Crawford voted for the Oregon Provisional government and served as a legislator for both Clackamas County and later Yamhill County, then guided emigrants across the trail. Mary Elizabeth spent her youth living between their Yamhill family farm and Portland, where she was educated at Saint Mary's Academy. Her future husband, Harley Stevens, was a first cousin whom Medorem Crawford had mustered into service in Missouri in 1862, to take care of the animals while travelling the trail to Fort Walla Walla. Harley Stevens then stayed and worked at the fort for several years but made his way to Portland in 1867 . He worked as a watchman and a bookkeeper for a time, until

\footnotetext{
140 Johna Heintz, “SCHH.pdf,” Archival PDF (Clackamas County Historical Society, Oregon City, Oregon) Accessed Fall 2020.
} 
being set up by his Uncle Medorem for a telegraph operator position at the Oregon and California Railroad station at Oregon City, where he stayed until retirement. ${ }^{141}$

Harley Stevens married Mary Elizabeth Crawford in 1871 in Yamhill and the couple then resided in Oregon City to be near the railroad station for his work. They had two children, daughter Muriel "Mertie" Stevens in October 1872 and a son, Harley Stevens Junior in November 1874. Mary Elizabeth would become a "charter member of the Ladies Aid Society" in Oregon City, president of several local committees and a member of the Congregational Church for fifty-six years. ${ }^{142}$ After Harley Senior retired from the railroad in 1889 , the couple lived on savings and money they had both "derived from fortunate investments in real estate." ${ }^{143}$ By the time the Stevens' built their new home on Sixth Street in 1908, they were well established local residents and Mertie and Harley Junior were already grown adults.

As a young woman, Mertie Stevens joined her mother in the Congregational Church and social clubs and was a skilled artist and pianist who often taught community members. Most importantly, she inherited and managed her parents' estate and, while she never married or had children, there is mysterious "evidence of companionships." 144 Mertie once commented that she had inherited her love of saving things from her father's

\footnotetext{
141 Obituary, “Oregon City Man of Note is Dead," Unnamed newspaper clipping (Museum of the Oregon Territory archive, accessed and scanned Fall 2020).

142 Obituary, "Death Calls Mary Stevens Local Pioneer: Well Known Local Woman Succumbs After Illness of Several Weeks; Funeral Sunday," Crawford Family Files, Accessed Fall 2020, Museum of the Oregon Territory, Oregon City, Oregon.

143 Johna Heintz, "SCHH.pdf," Archival PDF (Clackamas County Historical Society, Oregon City, Oregon) Accessed Fall 2020), 2.

144 Johna Heintz, The Stevens Family: A Brief History, Power Point presentation, (Clackamas County Historical Society, Oregon City, Oregon) Accessed Fall 2020, Slide 17.
} 
side of the family, while her acumen for business affairs came from her mother's line. ${ }^{145}$ Investment skills both Mertie and Harley Junior learned from their parents allowed them to also buy and sell various interests. Mertie was able to live "comfortably through independent means" and despite a few small financial squabbles between the two siblings over the years, Harley Junior had his own properties, and she was able to keep the family lots in Oregon City. ${ }^{146}$

Harley Stevens Senior passed away in 1924 and Mary Elizabeth Crawford Stevens died in 1932. The couple was buried in a family plot at the Mountain View Cemetery in Oregon City. ${ }^{147}$ Mertie Stevens continued caring for the family home and sustaining her income through real estate assets. ${ }^{148}$ In January of 1939, Mertie agreed to an interview with the Federal Writers Project and Sarah B. Wrenn came to talk with her about the house and family story. The oral history was part of the Works Progress Administration goals to provide jobs during the Depression years. Wrenn and other Oregon writers during this time made "twenty five to fifty dollars a month" gathering stories for the Oregon Folklore Studies Program. ${ }^{149}$

\footnotetext{
145 Vera Criteser, "Property Given to Historical Group," The Oregonian (September 9, 1959) Section 3, Pg.1.

146 Johna Heintz, "SCHH.pdf," Archival PDF (Clackamas County Historical Society, Oregon City, Oregon) Accessed Fall 2020.

147 Find a Grave, database and images (https://www.findagrave.com: accessed 27 March 2021), memorial page for Harley C. Stevens (7 Jan 1847-27 Jul 1924), Fina. Grave Memorial no. 93269690, citing Mountain View Cemetery, Oregon City, Clackamas County, USA; Link: https://www.findagrave.com/memorial/93269690/harley-c-stevens.

148 Johna Heintz, The Stevens Family: A Brief History, Power Point presentation, (Clackamas County Historical Society, Oregon City, Oregon) Accessed Fall 2020, Slide 25.

149 Tom Nash, Federal Writers Project in Oregon, (Oregon Encyclopedia: Oregon Historical Society). Link: https://www.oregonencyclopedia.org/articles/federal_writers_project_in_oregon/\#.YFviLy2z3BI.
} 
The project worker made several telling comments in her report, initially that the house was in "immaculate order, not only in the living rooms but in all the rooms adjoining." 150 After talking with Mertie, walking around the house and seeing the collection that was beginning to accumulate in the basement, Wrenn commented that she seemed "more interested in acquiring and possessing early Northwest Americana, than history of folklore." 151 At the end of the interview though, Mertie had "left the impression much remained untold" because she seemed too busy or unwilling to really talk. ${ }^{152}$ That said, the report is only eight pages and it seems Sarah Wrenn may have been in a hurry herself, trying to pry out the most pertinent information and move on to the next stranger on the list, rather than fostering an actual relationship with Mertie. Indeed, Wrenn conducted at least thirty-seven interviews between the fall of 1938 and spring of 1939, which were all typed and submitted by the writer to the project and are now available in the Library of Congress. ${ }^{153}$

Mertie was a notable figure in her own right, but she was also an important member of "a remaining vestige" of emigrant families in Oregon City, and she was committed to honoring that history through involvement with the Clackamas County Historical Society. According to museum staff, after that oral history interview her collecting habit seemed to spiral out of control, to the point where she almost filled up the house. Around

\footnotetext{
150 Sara B. Wrenn and Miss Mertie Stevens, Federal Writers Project: Early Oregoniana and Local Sayings, Oregon, 1939. Manuscript/ Mixed Material. https://www.loc.gov/item/wpalh001977/.

151 Sara B. Wrenn and Miss Mertie Stevens, Early Oregoniana and Local Sayings, Oregon, 1939. Manuscript/ Mixed Material. https:/www.loc.gov/item/wpalh001977/.

152 Sara B. Wrenn and Miss Mertie Stevens, Early Oregoniana and Local Sayings, Oregon, 1939. Manuscript/ Mixed Material. https:/www.loc.gov/item/wpalh001977/.

153 Sarah Wrenn, List of WPA interviews, Library of Congress. Accesses April 2021. Link: https://www.loc.gov/search/?fa=contributor:wrenn,+sara\&sp=1.
} 
1950, Harley Junior convinced Mertie to use their guest house, so that she could properly host group meetings. Unfortunately, the main house was becoming "extremely cluttered," as people around town kept giving her things, which she then piled into the house with little provenance. ${ }^{154}$ This created a problem for the museum later because poor record keeping at this time misplaced information about Stevens-Crawford family items. Additionally, the inventory list compiled by volunteers was created according to the layout of the house, so as items were moved over time, the list became no longer useful, accurate or relevant.

In June of 1963, Mertie Stevens organized the transfer of three properties to the Clackamas County Historical Society (CCHS), including the family home and guest house, in agreement that she would reside until her death. The generous donation was gladly accepted formally by CCHS, which would keep it as a "means of perpetuating the will and stamina of the pioneering traits" of her family and local life. ${ }^{155}$ The transaction greatly benefitted both parties, as Mertie had no heirs (Harley Junior's twin daughters lived too far away), and the historical society would now have a brick and mortar museum. In January of 1964, the society appointed a house committee of Wilmer Gardner, Vera Lynch, V.D. Butler, Virginia Rice and Edna Henderson to begin helping Mertie with a verbal inventory process of her properties. ${ }^{156}$ The next year, board minutes commented that the society needed to "work hard to save our historical landmarks" in

\footnotetext{
154 Johna Heintz, The Stevens Family: A Brief History, Power Point presentation, (Clackamas County Historical Society, Oregon City, Oregon) Accessed Fall 2020, Slide 28.

155 Board of Directors, Meeting Minutes (Clackamas County Historical Society, Oregon City, Oregon), July 1963.

156 Board of Directors, Meeting Minutes (Clackamas County Historical Society, Oregon City, Oregon), January 1964.
} 
Oregon City, which was an early sign of the second preservation movement and foreshadow to the National Historic Preservation Act in 1966. ${ }^{157}$

Mertie Stevens' health began to decline in May of 1968, and after passing away in July of that year, her properties were officially transferred to society ownership. She requested "no flowers and monies in lieu of to be sent to the Society," a testament to her humble and generous character and dedication to the group. ${ }^{158}$ In August, the society took over utility bills and insurance, while board members took turns staying at the main house to protect the collections. The house committee was given "authority to select items to be sold" and they held a members-only event first, followed by a public yard sale that October, and cleaned up the property as best they could. ${ }^{159}$ The main Stevens home and collection "officially put CCHS on the map" because now they had a physical public museum location, instead of having to use the city library or the guest house for meetings. ${ }^{160}$

After a "fast collaborative effort" staging the main and second floors, the Clackamas County Historical Society opened their new house museum to the public in $1969 .{ }^{161}$ Over the next decade, volunteers started "going through, identifying, [and] creating documentation" for the extensive collection, with over one thousand accession folders

\footnotetext{
157 Board of Directors, Meeting Minutes (Clackamas County Historical Society, Oregon City, Oregon) August 1964.

158 Board of Directors, Meeting Minutes (Clackamas County Historical Society, Oregon City, Oregon), July 1968.

159 Board of Directors, Meeting Minutes (Clackamas County Historical Society, Oregon City, Oregon), August 1968.

160 Our History (Clackamas County Historical Society, Oregon City, Oregon), Accessed Fall 2020. Link: http://clackamashistory.org/our-history.

${ }^{161}$ Liza Schade, Johna Heintz interview, Oral history: notes from raw footage, Public History class, Dr. Katy Barber, Portland State University, Created Fall 2018.
} 
organized with as much information on known items as possible. ${ }^{162}$ Simultaneously though, the society was "literally dropping objects into every nook and cranny," not unlike what Mertie had done for years. ${ }^{163}$ It is likely that this small historical society with a close community bond did not feel comfortable declining donations at that early juncture in their time as a public museum. The Stevens Crawford Heritage House continued to remain the society's headquarters but hunkered into a stale and inaccurate Victorian era narrative, presenting occasional exhibits in the living room or displays in the reception hall focused mostly on the occupations and pastimes of Medorem Crawford and Harley Stevens Senior. They had a good volunteer base to help with maintenance and provide tours, but stories told by guides became inflated with a prominence that lessened their appeal to the public over time, while collections and dust continued to accumulate.

Between 1985 and 1990, a new contemporary museum building was constructed overlooking the Willamette Falls and became the main public repository and exhibition space for the society, but that space also faced challenges of its own. The new museum (still run by the Clackamas County Historical Society) underwent several name changes, but the board and staff finally decided on the Museum of the Oregon Territory. Despite the excitement of a new location, they remained committed to keeping the StevensCrawford Heritage House open for tours, cataloging collections, and honoring the contributions made by Mertie and her family to local history. However, the society did

\footnotetext{
${ }^{162}$ Liza Schade, Johna Heintz interview, Oral history: notes from raw footage, Public History class, Dr. Katy Barber, Portland State University, Created Fall 2018.

${ }^{163}$ Liza Schade, Johna Heintz interview, Oral history: notes from raw footage, Public History class, Dr. Katy Barber, Portland State University, Created Fall 2018.
} 
not change the way they engaged the public at the house through the 1990s and 2000s, outside of annual Christmas and local club events, especially because they were challenged by funding limitations and priorities for the larger site. From the time the house museum was opened to the public, the society continued to keep hours of operation two days per week, but "visitorship has always struggled, before and after the museum building opened at the falls."164

\section{Rethinking the Stevens-Crawford Heritage House}

Awarded the Oregon Museum Grant in 2018 for new storage supplies to care for sensitive and disintegrating collections, museum staff used this funding to launch a new reinterpretation plan at the Stevens-Crawford Heritage House. Clackamas County Historical Society Director, Jenna Barganski, and Collections Manager, Johna Heintz led the charge which, after board approval, "encompassed full reorganization, inventory, and staging of the rooms, including decades-old maintenance and repairs." 165 Another important goal was to remove the "restrictions of a guided tour," allowing guests to roam all over the house and enjoy the details of the home according to their own varied interests and curiosity, while having educational interpretive panels and volunteers available for those who want to learn and engage. ${ }^{166}$

Heintz and Barganski were responsible for applying for the grant, determining goals, planning, and implementing the project, as well as collaborating with Portland State

${ }^{164}$ Liza Schade, Johna Heintz interview, Oral history: notes from raw footage, Public History class, Dr. Katy Barber, Portland State University, Created Fall 2018.

165 Johna Heintz, Quote from edits to this thesis chapter, accessed on April 17, 2021.

${ }^{166}$ Johna Heintz, Quote from edits to this thesis chapter, accessed on April 17, 2021. 
University to utilize and train interns. The two professionals delegated and supervised tasks, making quick decisions when issues needed solutions, getting dirty moving boxes and furniture, ordering storage supplies, and cleaning out dark and dusty corners. As the collections work progressed, it was important to Johna Heintz to do several things: first, to identify and exhibit family artifacts and other items that helped to interpret narrative and second, to aid in deaccessioning duplicates or relocating items to places that may benefit from their original history. Third, Johna Heintz wanted to complete a full inventory and reorganization of collections storage at the main museum based on standards of nomenclature, as well as improve and clean out storage at the house. In the fall of 2018, our public history class working under Professor Katrine Barber relocated textile artifacts from a large portion of the Stevens-Crawford attic to main museum storage, emptying six large antique trunks full of logging boots and stiff collars for men, as well as shoes and accessories for women, and children's clothing. Our class researched interesting items and carefully stored them according to best practices, in blue collections boxes with acid free tissue. We also inventoried the items for easier cataloging in the Past Perfect 5.0 software system that is utilized by the museum. Two teams of students created digital assets that the museum could post online as well, including one video about the house and trunk collection and one about how to work with artifacts, as well as a few fun memes for social media. As a graduate student in the class and project team member, I helped with overall planning, documentation, and data organization, and led students in the care and management of the objects found in the trunks in the attic (having professional experience with museum collections). 
After that term was completed, I stayed on with the museum as an intern to conduct individual graduate fieldwork. I assisted in many tasks, such as removal of nonarchival clutter from the basement (old newspapers, magazines and even notes written by Mertie Stevens) and installing new steel collections shelving. Additionally, I reorganized trunks and chairs in the attic, and relocated boxed clothing and hats which filled upstairs closets and a storage room to the newly designated textile storage space at the main museum, where I arranged everything on shelving by general nomenclature. Over the fall of 2020, I researched archival records into family history and Clackamas County Historical Society board minutes up to 1970 , to determine how the Stevens-Crawford house became a museum. ${ }^{167}$ In June of 2021, I will return to participate in a virtual living history event at the house in live time, where we will recreate an historic photo of a group of Edwardian era women sitting together sewing stars onto a flag. That is just one part of a personal effort to continue volunteering and to maintain a long time friendship with the Clackamas County Historical Society, happily offering support whenever possible.

\section{Factors that Affect the Stevens Crawford Heritage House}

\section{The Clackamas County Historical Society itself was formed in 1956, with Mertie}

Stevens as a founding member and the group initially held meetings in her guest house.

The society technically became a museum with the opening of the Stevens-Crawford Heritage House in 1969, which then became a repository for all things related to

\footnotetext{
167 Covid-19 restrictions prevented going back to MOOT to finish going through archival records, specifically board minutes after 1970. Further work will reveal more about how SCHH was interpreted in the modern era, however information to help fill gaps has generously been provided by collections manager, Johna Heintz.
} 
emigrants and county history. However, despite their growing presence in the community and the necessity of a larger site, the potential of the house receded when the new building above the falls opened in 1990 . Volunteers continued to give tours and catalog collections, but people lost interest quickly, visitorship remained low and unrestrained artifact donation added to the problem of clutter.

Board minutes have not been accessed after 1970 yet (due to Covid closures), to find out exact levels of volunteer participation and staffing over the last few decades, but the society was volunteer-run until the larger new building necessitated hiring paid employees. From the 1990s on, the board has overseen the society mission and the museum has been staffed by an executive director and collections manager, as well as marketing and administrative personnel, who all work together to manage the house. The latest annual report, from 2018-2019 (pre-Covid), announced the reopening of the house after initial reorganization, and the opening of a capital campaign to raise funds for future renovation and reinterpretation at the house. According to former board President Bruce Hanson and current Director Jenna Barganski, the goal was to "raise the necessary funds to open the house as a meeting space and event venue."168

The Stevens-Crawford Heritage House was relevant to the second preservation movement, during the 1960s when important legislation created standards for significance, integrity, eligibility, and protection of historic sites. The third preservation

\footnotetext{
${ }^{168}$ Annual report 2019, "Letter to CCHS Members and Friends," (Clackamas County Historical Society, Oregon City, Oregon), 4. Link: https://drive.google.com/file/d/1zgD_ja2ttO-9y-

dALBGbDnYZgfe0Q6ft/view.
} 
movement in the 1990s and 2000s helped to procure protection for the entire McLoughlin District (and indirectly the house) and now participation in the fourth movement is creating opportunities for the Stevens-Crawford house as an individual site within that district. In the spectrum of preservation, the site generally sits in the medium house museum section of the spectrum, with historical society ownership, well maintained grounds, an active board and staff and volunteers dedicated to new projects.

The historical society underutilized this site in early stages of development, proper collections organization was "lost over the decades" due to a lack of trained archivists, and narrative remained focused on architecture and male prominence. ${ }^{169}$ Fortunately, the collection and museum are being well managed now and restaging has been accomplished to a workable extent, while sustainable public uses are being actively innovated and experimented with. Methodology, public access, and funding have been the biggest issues over time, but efforts by board members and staff have made a difference and site presentation and management has noticeably improved. The goals in the future will be to provide committed maintenance and support, but more importantly to improve engagement with the community and historic district, as well as the coalition on the Willamette Falls heritage area, to find a more impactful place in the community and be a model for other sites (and districts) that are undergoing re-interpretive projects.

\footnotetext{
${ }^{169}$ Liza Schade, Johna Heintz interview, Oral history: notes from raw footage, Public History class, Dr. Katy Barber, Portland State University, Created Fall 2018.
} 


\section{Methodology at Stevens-Crawford Heritage House}

Methodology refers to the entire reinterpretation project, including collections, research, and restaging, as well as creation of future programming and uses for the Stevens-Crawford Heritage House. Museum staff have done an exceptional job with this complicated long-term plan because they are finding a delicate "balance between caring for collections and providing meaningful and interactive visitor experiences." 170 Collections must be constantly monitored and inventoried in two locations, while reinterpretation includes perpetual research, story revision and re-exhibition, then community agency and careful planning for programs and events. Reinterpretation of an entire house museum is a complicated operation that requires teamwork, collaboration, interdisciplinary expertise, and public involvement. At the Stevens-Crawford site, the initial method of dealing with the cluttered collection paved the way for restaging, which in turn gave the public better physical and educational access.

As mentioned above, the grant awarded to the Clackamas County Historical Society in 2018 included funds for purchase of acid-free museum supplies to properly store artifacts. Initial action to preserve collections is crucial in any reinterpretation project, but especially in a historic house with a lack of modern heating, ventilation, and air conditioning. While the site is in wonderful condition compared to others that need extensive work, it is still not up to the standards of preservation for sensitive materials. Most at risk items were prudently moved to the larger museum storage where the temperature is consistently regulated, while housewares and kitchen goods were boxed

170 Turino, 123. 
and moved to new shelving in the basement, which maintains a consistent temperature due to residual warmth from the main body of the heating system. Careful decisions were made about what could be stored downstairs, as well as how to repaint interiors with historically accurate colors and restage rooms with Stevens family belongings or pertinent materials to their lifeways.

In the past, long time volunteers tended to enjoy a "lightly monitored autonomy," so a few resisted changes when the contemporary reinterpretation project was initiated. ${ }^{171}$ One or two even reacted to college interns who had been hired to clean out collections, blocking them from removing trash or modern items, to go through them for fear something valuable might be lost. ${ }^{172}$ Revising facts about the family and making "narrative changes were pushed back on" by those volunteers that had been set in traditional models of unfettered collection practices, prominence and national myth. ${ }^{173}$ However as the project began, museum staff nurtured their vested interest by carefully and firmly explaining why changes were necessary and how they had come to new research conclusions. Once those skeptics were shown proof of factual data (that had to be changed in new interpretive panels) and they understood why revisions were necessary to present the correct era and broaden perspectives, the challenge seemed to melt away as everyone adapted.

\footnotetext{
171 Johna Heintz, Quote from edits to this thesis chapter, April 16, 2021.

${ }^{172}$ Confrontations with long time volunteers occurred with both me and one other intern. Personally, I was cleaning out the basement of modern garbage and one of the retired volunteers stopped me. I reassured her that I was a professional, plus there were no artifacts that were being thrown out.

${ }^{173}$ Liza Schade, Johna Heintz interview, Oral history: notes from raw footage, Public History class, Dr. Katy Barber, Portland State University, Created Fall 2018.
} 
Restaging the home with furniture and belongings that portray active lifeways and original family use connected the collections care with the work of reinterpreting narrative and showed how closely the two go hand in hand. Jenna Barganski and Johna Heintz thought deeply about how to correct the time to the Progressive-Edwardian era, which was full of inventions and innovations, and they greatly broadened perspectives from a prominent male view to one that shows the whole family. The team wanted to bring Mertie Stevens and her mother Mary Elizbeth into focus because the two women had actually "legally and solely owned the house and the land it sat on," not the men in the family. ${ }^{174}$

The furniture from the bedrooms of both Mertie and her parents were returned to their original rooms to present a more accurate picture of their lives. Mertie's room had been previously misrepresented as children's room with an elaborate display of vintage toys, even though no children ever resided there. Harley Senior's office is no longer a gift shop, but staged with his actual desk, chair, and typewriter, along with architectural designs for the house and interpretive panels on the wall. Johna Heintz also explored how to tackle controversial topics, such as educating visitors about a collection of indigenous projectile points gathered by the family patriarch. She wanted to make sure to respect tribal history and contemporary Native American culture centered around the Willamette Falls, recognizing, and advocating for their right to carry on cultural traditions and fish for lamprey there. Other narratives will include more comprehensive histories of each member of the family, people that may have worked for them at the house, local church

\footnotetext{
174 Johna Heintz, Quote from edits to this thesis chapter, April 16, 2021.
} 
and social clubs that have been connected to the site history and more. They can even provide information on how to be active in modern preservation goals at the house and within the McLoughlin District.

Once the collections and exhibitions were completed, the house was reopened to the public in the summer of 2019 for open unguided visitation, allowing free exploration at the leisure of every individual, rather than pushing people through a limited time, no talk, no touch tour. The museum was once again opened two days a week and there was a marked increase in visitorship in the months that followed. However, the current pandemic has now completely prevented the public from accessing the site, thereby affecting what numbers would have looked like under normal circumstances. Prior to Covid-19, the main museum above the falls was open five days a week, but shut down completely through 2020, with only staff and restricted access allowed. However, the society reopened its doors for a ten person limit in April of 2021 and hopes to reopen the Stevens-Crawford Heritage House in the summer. In June, the Edwardian Society of Oregon will host a virtual living history event at the house. A group of volunteers, including myself, will dress in period costume and recreate a picture of several women in 1920. Staff are also planning an exterior garden landscaping project at the house, where volunteers can safely help restore the garden to the Edwardian era, when picnics and garden clubs were once popular in Oregon City.

History students will be able to continually earn credits working in the house, the main collections storage and the museum archive. However, education students will have to wait until full grade school activities resume to come back and help with field trips. In the 
house specifically, the staff, volunteers and interns will continue to inventory and research artifacts, participate in exhibit creation and installation, and submit new ideas for interactive events, which could later be implemented or revised. While my thesis work will end with graduation in June 2021, I will continue to volunteer at the house and plan to create a video about the history of the property for use on social media.

\section{Public Access \& Engagement at Stevens-Crawford Heritage House}

The Stevens Crawford Heritage House was "truly a neighborhood historical society" at first because of the early membership local families who donated and in the 1950s. After the non-profit took ownership in 1968, they seemed excited to make it into a public museum, but over time its prominence as an important landmark lost its luster in the Oregon City community. ${ }^{175}$ When the new museum building above the falls opened in 1990, former Director Bob Monaghan did a newspaper interview about their new exhibit on Medorem Crawford's pioneer history. Monaghan said that the house was open to the public, but much of the collection was "stored in archives for protection and isn't normally on display," a comment which took away incentive for people to see the site. ${ }^{176}$ In terms of public access and engagement, the article provides evidence that the museum was not really interested in either showing the house or connecting to the community on

\footnotetext{
175 Liza Schade, Johna Heintz interview, Oral history: notes from raw footage, Public History class, Dr. Katy Barber, Portland State University, Created Fall 2018.

176 Dan McCue, "Oregon Trail a paper trail, too," The Oregonian, June 10, 1993 (Accessed from "Medoreum Crawford" file in Museum of the Oregon Territory archive).
} 
top of the bluff, but rather exhibiting a curated collection focused on earlier emigrant history at the main museum only.

Prior to reinterpretation, guests were always led on guided tours and generally did not want to stay long. According to Johna Heintz, their "eyes glazed over and they got bored." 177 There are many reasons for this common public response, including clutter, dust and dark lighting, disconnected narratives, unskilled tour guides, ambivalence by boards or staff to pursue projects or any other number of issues. However, historic house museums are "increasingly pressured to demonstrate their value and relevance" in contemporary life, which is why there has been a shift to a more diverse perspective in current policy and practice. ${ }^{178}$ Very often if they do not contribute to a community, or show continuity between history and contemporary life, it is because of the "insistence on adhering to old museum models," which makes them vulnerable in a field that is currently challenged to improve. ${ }^{179}$

While the changes made between 2018 and 2021 (Covid-19 aside) improved physical visitation, increased informational access is essential to connecting to the larger outside public. Visitors can now walk into a less cluttered, more inviting aesthetic and even touch many items, listen to music on the Victrola and flip through Mary Elizabeth and Mertie's handwritten recipe cards. New exhibit panels in the office used by Harley Stevens Senior show the original floor plans drawn up by C.C. Robbins and architecture fans can

${ }^{177}$ Liza Schade, Johna Heintz interview, Oral history: notes from raw footage, Public History class, Dr. Katy Barber, Portland State University, Created Fall 2018.

${ }^{178}$ Frank D. Vagnone and Deborah Ryan, Anarchist's Guide to Historic House Museums: A GroundBreaking Manifesto (Left Coast Press: Walnut Creek, CA, 2016), 35.

${ }^{179}$ Vagnone, 49. 
contemplate unique elements throughout the interior and exterior of the property. The effort to provide a tangible experience for visitors, expand research and place more digital assets online will provide better relationship building with the community and informational access in the future.

Digitization has become a crucial part of modern museum and archival practice and is an important part of this fourth preservation movement. To increase organization and access to records, digitization utilizes "an expanding range of technologies" to address informational needs and create new activities for online learning. ${ }^{180}$ In terms of cataloging collections, scanning technology is making for more efficient record keeping and less handling of primary documents, as well as the ability to share data online, with researchers or other organizations. Curated pages on history based websites provide endless ways to creatively make and share content, and communicate with the outside public about a site, as well as asking for input on current and future projects.

For example, the public history class from Portland State University created two videos as digital assets for social media; one included an interview with Johna Heintz about the reinterpretation project and one provided a "professional examination of the inventory process." ${ }^{181}$ The Clackamas County Historical Society also partnered with the travel website called Vamonde in June of 2020 to create a digital tour of the Stevens-Crawford house, providing eight webpages of information and pictures of four rooms, a history of

\footnotetext{
${ }^{180}$ Douglas A. Boyd and Mary A. Larson (Eds), Oral History and the Digital Humanities: Voice, Access, and Engagement (New York: Palgrave MacMillan, 2014), 1.

${ }^{181}$ Public History PDX, "Junk in the Trunks: Reinterpreting the Stevens-Crawford Heritage House," (Portland State University History Department, February 25, 2019). Link: http://publichistorypdx.org/2019/02/25/junk-in-the-trunks-reinterpreting-the-stevens-crawford-heritagehouse/
} 
the family, information on the architecture, life and technologies of the Progressive era and significant events in the area. ${ }^{182}$ The public can also find facts about the site through the museum website and Facebook, and by researching archival records and photos at the museum archive. Much more online sharing is needed to showcase the space and its expanded history, and garner renewed support.

Public engagement refers to not only connecting to visitors and the outside public, but also partnering with residents, businesses, and other historic homes in the district, which was not fulfilled at the Stevens-Crawford house in the past. It is important not to fault the current museum staff and board for that problem, as they are not responsible for the early lack of collaboration. Despite many challenges, the society did a good job with the resources they had available to open the larger museum site above the Willamette Falls in 1990. The board knew that the house could not last forever as a main repository and that a larger museum site was needed. Moving became inevitable, but it is also commendable that they did not sell the house or let it fall too far into disrepair over the years.

There are some opportunities for Stevens-Crawford Heritage House, such as an internship program with Art in Oregon to work with artists to display their creations in the upstairs hallway. Once reopening occurs, regular book club meetings will resume, and Johna Heintz and Jenna Barganski are developing a plan for renting it as a wedding venue and meeting space. The society does have limited staff time and funding, but persistently creating relationships with other historic sites in the McLoughlin District,

\footnotetext{
182 Vamonde.com, “An Introduction: Welcome to the Stevens Crawford Heritage House,” Link: https://www.vamonde.com/posts/an-introduction-welcome-to-the-stevens-house/9911/
} 
along with SHPO, the City of Oregon City and nonprofits like Restore Oregon, could also provide new support that has not been given in the past.

Additionally, the Willamette Falls and Landings Heritage Area Coalition (WFLHAC) is working with a group of public, private and non-profit businesses, along with six local governments, to "enhance, assist, and promote" a legacy area along the river from Lake Oswego all the way down to Wheatland, Oregon. ${ }^{183}$ The public never gets to see the second largest waterfall in the United States after Niagara Falls in volume, so the project seeks support in establishing a National Heritage Area, to preserve the history, beauty and agricultural places and create recreational space for the public on the water. The society is already working with this coalition as a new priority contact, to provide research records and provide input on what the heritage area should look like and what history it should include, as well as promote their own organization.

At the house specifically, future public programming can include school tours, experts to give lectures, oral history interviews, events that show off Progressive era technologies, videos with local cable stations and graduate students, and even daily social media posts, like questions or mysteries to solve about different objects or people. Additionally, new programming could include local tribal members to talk about cultural lifeways around the Willamette Falls and the importance of sovereignty and carrying on their ancestral traditions today. Surveying public opinion and involving the community in decisions about the house and narrative are vital, so attending regular city meetings,

\footnotetext{
183 “Our Coalition,” Willamette Falls \& Landings Heritage Area Coalition webpage, Accessed April 2021. Link: https://www.wflha.org/about/
} 
polling the neighborhood around the site about what they want to see and closely collaborating with those willing to help will ensure an open door policy in the future.

\section{Board Capacity at Stevens Crawford Heritage House}

The Clackamas County Historical Society took on this historic home at the exact time the NHPA legislation and procedures became a reality, and it has continued to care for it as a house museum for five decades now. Prior to 1968, the house committee appointed by the board worked closely with Mertie Stevens to ensure that her wishes were met, allowing her to live on the family property, holding events at her guest house and accepting her help to begin some semblance of collections sorting, by telling them about items and stories about the two families. After Mertie Stevens passed though, the committee went much too quickly to clean out the house and sell furniture, and likely lost information about important items directly related to the site. The board should have taken much more time to sort through collections, to carefully inventory and preserve known items with provenance. Some cataloging action did occur from the 1970s on, as noted by Johna Heintz, but as is a common problem in many museums, they could not say no to donations and took anything from locals, friends, family, and volunteers. Consequently, this resulted in a major mixing of artifacts, to the point where things either disappeared or had too many duplicates, were damaged or just simply had unknown donors or stories attached.

Admittedly, more archival work is needed to fill gaps about specific board actions between 1980 and 2010. However, it was made clear from other ephemera, such as news 
clippings about the museum in those years and conversations with staff, that very little was accomplished at the house, except to hold occasional events and keep the space open for limited guided tours. The Clackamas County Historical Society board is currently composed of four officers, Linda Meyers (President), Chris Owens (Vice President), John Salisbury (Secretary) and Steve Bennett (Treasurer), along with nine other sitting members who all work together to make decisions about both the main museum and the Stevens-Crawford Heritage House.

Physical implementation of the reinterpretation project has largely been the work Jenna Barganski and Johna Heintz. They were perfect people to do the project because they understood why contemporary use is necessary to sustainability of the property under society ownership. Barganski has collections management experience, and as a recent PSU alumna, she knows that reinterpretation is key to participating in social justice and the current preservation movement. As general manager, the most important part of her job is to promote the house and main museum, to renew and increase funding, and to inspire awareness and support. Johna Heintz now has almost a decade of experience working directly with both the society and house museum collections. She has also extensively researched the family history and knows the needs for storage and curation more than anyone at this moment.

With the board, staff, college interns and regular local volunteers working together, the larger team has made a direct impact and breathed new life into this historic home site. However, it is the board's legal responsibility to ensure the long term sustainability of the society and both museums, which means careful strategic planning and participatory 
stewardship. The next challenge is how they will continue to work with the public to keep the Stevens-Crawford house sustainable as a museum and community space. Most recently though, the stress of Covid on the finances of the museum has forced the board to make hard decisions, but some staff have continued to work partially from home and partially on site when needed. The board will need to be vigilant in campaigning for funding, but thankfully the public and visitor numbers should climb back up to normal in the summer (and hopefully increase).

\section{Funding at Stevens Crawford Heritage House:}

Forty percent of funding for the Clackamas County Historical Society comes from rentals of the Tumwater Ballroom, which takes up the entire third floor of their main building on the bluff. With large windows providing a view of the powerful Willamette Falls, the society provides the space for weddings, Rotary club meetings, school field trips and other community gatherings. As with any non-profit, other relevant revenue usually comes from museum admissions, donations, trusts, grants and fundraising events. Part of the annual budget provides for small repairs and property taxes at the house, but major interpretive work always needs grants and donations to be accomplished.

Funding for the society has always been a challenge and Covid-19 greatly impacted visitation and revenue in 2020 . Over the years, there have been a few guilty whispers about selling the house to keep the larger museum afloat, but thankfully the board of the society has never acted on them and refrained from going in that direction during the pandemic as well. Grant funds were useful in the beginning of the 2018 reinterpretation 
process and major teamwork and volunteer participation helped to accomplish collections organization and restaging. Nevertheless, much more support will be needed to maintain the property as a sustainable house museum and engage the public on a continued basis.

Now that the main museum is open, revenue should slowly return, but that was never enough to begin with, due to a lack of support from the county. As mentioned, the entire heating and cooling system also failed in 2020, which took a major toll on finances too. Their website still has calls for donations because of that unforeseen disaster on their budget, but the system has now been replaced. Museum staff will apply for more grant funding to create and implement more collections work and create digital assets and programs that enhance the site, which will take time, patience and continued hard work. Plans are in process to rent out spaces in the home for events or even small businesses as well, which could increase revenue and help with repairs, maintenance, and programming projects. Since I am not faculty, it is difficult to say what financial planning will look like in the future, but the current board and staff provide good stewardship and can launch capital campaigns and other types of fundraisers to garner support.

\section{$\underline{\text { Conclusion }}$}

The Stevens-Crawford Heritage House is one of the only originally sited historic homes in the McLoughlin District, which makes it more significant than others that have been moved there to save them from demolition. The Clackamas County Historical Society is important as a local leader, and it is fitting that they should participate in the current heritage and preservation movement and reimagine their site as an example to others. This historic house project contributes to similar changes going on at sites all over the 
country and reflects the continued evolution of the field in the current movement. New methods of working with collections and interpreting narrative are redefining how historic homes are safeguarded and presented to the larger public. The society board and professional staff are taking risks and participating in that change by recreating the Stevens-Crawford Heritage House into an experimental model for both historical education and living use.

However, interpretation is an ongoing task, not a project that is ever fully completed. The process requires consistent long term attention to professional standards, detailed research, and activism in social justice, while consistently inviting the input of stakeholders for new ideas and commentary. Johna Heintz has been very successful in upgrading collections practices, both at the main museum and the Stevens-Crawford house, as well as researching the appropriate period, including new narratives about the women of the family, and providing a cleaner, more inviting space for visitors to guide themselves through. Had it not been for Covid-19, visitorship would likely have continued increasing and staff would have been able to hold events at the site, make deals with small businesses, and engage in broader community projects, like the heritage area by the Willamette Falls. As vaccines continue to roll out and business slowly resumes, the museum will hopefully be able to regain some lost revenue, reopen the house museum and resume those tasks by fall of 2021. Staff know that narrative research must continue, along with digitization of records, creation of online assets and onsite programming. The museum should also remain in partnership with local colleges to 
provide intern training, so students can gain credits and experience and help accomplish important future tasks.

Findings from this case study support what modern preservationists and public historians are doing to update historic homes and bring them into current professional policy and practice. According to Turino and Balgooy, "results must be unique and distinctive" to each house museum and the staff at this site are ensuring that the more contextual, accurate and inclusive narrative, along with innovative and interactive programming will work to that end. ${ }^{184}$ Methodology has been flexible, not following a strict map laid out by complicated data accumulation (as the Anarchist authors would have each site play out), but guided by academic collections care standards, experimenting with trial and error and implementing what programs work.

My own fieldwork and research have contributed to progress at the Stevens-Crawford Heritage House in several ways. First, I was able to pay forward some of my own knowledge and skill in collections to other graduate students in that initial public history class, where our two teams helped to store objects and create videos. As an individual intern, I completed over sixty hours working in the basement and attic, as well as helped to organize storage at the main museum, among other tasks. However, the most important contribution was writing the above history of the site, taken from archival records, as the museum does not have anything else as comprehensive. ${ }^{185}$ More archival research into board involvement after 1970 is needed, which should be incorporated into a video about

\footnotetext{
184 Turino, 3.

185 There was also much information that could have been added about the family history, however the larger thesis topic prevented a longer narrative in this paper.
} 
the house history for promotional use, but that will be included in the next step in studying and rethinking this site. My participation as a graduate student may be concluded, but I will continue to volunteer with the Clackamas County Historical Society and other heritage related non-profits. As a professional, my goal is to be involved in new collaborations, to inspire awareness and support to all kinds of historical organizations and sites, and to help accomplish reinterpretation that creates continuity and connection with the public.

Chapter Three brings readers to a site in Bend, Oregon, which has a more recent history and was donated under a different set of circumstances. However, even though the next house museum is under a special type of contemporary ownership, the space is undergoing a similar reinterpretation project. A mid-twentieth century ranch with historic connections to early irrigation, experimental farming and family sharecropping, the Hollinshead-Matson Historic House and Tack Shed is being transformed through a new type of partnership occurring in this state. Unlike Clackamas County Historical Society, with individual ownership and strategic planning, an association between the parks district and historical society in Deschutes County has created a unique model for historic house museums to follow in this state. 


\section{Chapter Three}

\section{Timberlane Ranch: The Hollinshead-Matson Historic House \& Tack Shed}

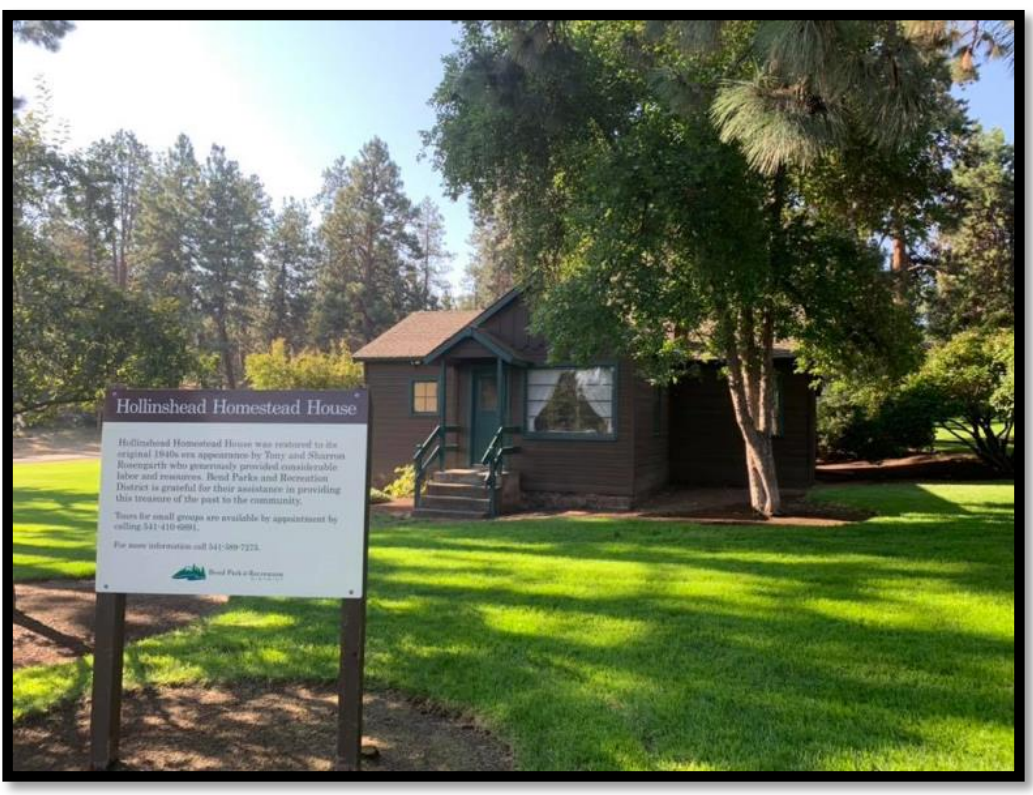

Figure 2: Liza Schade, iPhone image of the Hollinshead-Matson Historic House, Bend, Oregon, August 2019.
Hollinshead Park is a

sixteen-acre public recreation area nestled in the residential Orchard District of Bend, Oregon. The Hollinshead-Matson Historic House and Tack Shed $(\mathrm{HMHH})$ are both located within the park,

along with a restored barn and outbuildings, a community garden, natural areas for enjoyment and off leash dog walking. The original one hundred and sixty acre ranch changed hands several times between 1908 and 1939, when it was finally bought by Dean and Lily Hollinshead. The couple owned the property for the rest of their lives and built a new home on top of the hill. However, they sharecropped for the first ten years with James and Virginia Matson, who lived at the bottom of the hill in the original homestead house that is the focus of this case study.

The Hollinshead home at the top of the hill has since been torn down, but the tack shed (also called the bunkhouse) and the old homestead house where the Matson's lived are still in good condition. The two buildings are currently undergoing reinterpretation through a partnership between Bend Park and Recreation District (BPRD), current owner 
of the property, and the Deschutes County Historical Society (DCHS). The first half of this chapter discusses the history of ownership and how the property became a public site, then outlines the project to preserve collections and restage the house and tack shed, including graduate fieldwork conducted in August of 2019. The second half provides analysis following the framework of four factors outlined in chapter one and makes recommendations for the future of the site.

Locals use Hollinshead Park regularly because the grounds are immaculately maintained by BPRD and the community garden is cared for by volunteers from the Central Oregon Master Gardeners group. ${ }^{186}$ Additionally, the broader public often uses the renovated barn for weddings and events. Those benefits create great potential for increased public access and engagement at the historic house and tack shed. However, the house and tack shed have not been regularly opened to the public in the past, except for occasional pre-scheduled tours through the parks district, hosted by one of the Matson children. Once collections work and restaging are complete, staffing and programming will be crucial to the future use of the Hollinshead property as an historic site, and subsequently expanded use of the park.

Like the Stevens-Crawford Heritage House discussed in the previous chapter, accomplishing the initial goal of inventorying, preserving, and storing sensitive and duplicate objects allowed for the next step in reinterpretation methodology to occur, research and restaging. The parks district and historical society will also define a longterm strategic plan for opening the house and planning activities and events that would be

\footnotetext{
186 The Central Oregon Master Gardeners group is an extension of the Oregon State University Master Gardener Program, which trains volunteers to serve in Crook, Deschutes, and Jefferson counties.
} 
of interest to residents and visitors. Both organizations in the partnership have skilled staff members, as well as boards that can accomplish planning and fundraising, with five members at the park district and nineteen members at the historical society. It will be important to keep a continued relationship between partners, to apply for grants, use networks to gain awareness and support, share marketing and digital assets, and hold heritage events. Actions like those will ensure future funds for staffing, programming and maintenance at Hollinshead-Matson Historic House and Tack Shed.

\section{History of Hollinshead Park: From Government Land to Historic Site}

Two geographic features are important to the early history of Hollinshead Park: the Deschutes River and Pilot Butte State Scenic Viewpoint. The modern residential Orchard District where the park resides is composed of the original historic parcel and is bordered by the Deschutes River on the west side, which continues to be a key water source for the whole region. When the Central Oregon Irrigation Canal was constructed between 1904 and 1907, water from the river was diverted through the original acreage for irrigation and livestock, running east along the north base of Pilot Butte. ${ }^{187}$ An extinct volcano that sharply rises in elevation from 3,600 feet to 4,138 feet, Pilot Butte became a protected state scenic area in 1928 , with a winding one mile trail up to a full panoramic view at the top. ${ }^{188}$ The western portion of the Hollinshead ranch was located at the lowest level of

\footnotetext{
187 "Mission Statement: History section," Central Oregon Irrigation District, Accessed April 2021. Link: https://coid.org/about-us/

${ }^{188}$ Karen Johnson, "Pilot Butte State Scenic Viewpoint," Oregon Encyclopedia, Portland: Oregon Historical Society, Accessed April 2021.

Link: https://www.oregonencyclopedia.org/articles/pilot_butte_state_scenic_viewpoint/\#.YIhf2C2z3BI
} 
this area on the north base of Pilot Butte, with the eastern half of the property rising uphill toward the peak.

The Warm Springs tribe occupied the land around Pilot Butte for countless generations, using it as a lookout point for protection and game hunting, as well as the nearby Deschutes River as a life-giving resource for water and salmon. Bands moved seasonally between winter and summer villages, often trading with Wasco tribes to the north and Paiute to the southeast. Today these three groups make up the Confederated Tribes of Warm Springs and continue to make an impact shaping and protecting Central Oregon. Early trappers like Peter Skene Ogden came through the Deschutes River region in the early 1800s and several land surveys of the area were later conducted by the US Army. Oregon Trail emigrants used the fordable bend in the river to cross on their way to the Willamette Valley after 1850, but a few stayed to raise families in the harsh high desert and eventually platted out a township by the turn of the century. Sawmills and ranching became early primary industries in Bend, Oregon, which was finally incorporated as a city in 1904 with about three hundred residents, mostly single male loggers and families spread out on farms with close access to the river.

Logging and infrastructural improvements paved the way for farming and irrigation. Initially, the city gained access to shallow aquifers located just under the top layer of volcanic rock throughout the region during the first decade of the twentieth century. This resulted in a period of canal building that would push the development of an "expanded irrigation culture" around the Deschutes River, by selling water rights to farmers. ${ }^{189}$ The

\footnotetext{
${ }^{189}$ Hugh Roe Davidson, Bent to Nature: Bend, Oregon as a Case Study in Twentieth Century Property Development, PSU Dissertation, December 2005, 70.
} 
Central Oregon Irrigation Canal (COIC) was constructed through the original

Hollinshead property, providing water for crops and livestock. Developed under the 1894

Carey Act, the COIC was built to "stretch across the arid acres of east Bend," to create

fertile farmland out of the high desert and attract new residents. ${ }^{190}$ Until then, early

ranchers had to dig wells on their individual properties to have enough water for their gardens and animals.

\section{Retired forester Bernard G. Duberow's report History of Hollinshead Park: Formerly}

Timberlane Ranch provides the only full description and use of the property from settlement through creation of a public park and house museum. One file of archival records at the Deschutes County Historical Society and two boxes of information in binders at the park district office provided photographs, individual histories, land records and newspaper articles related to the property, which all validated Duberow's research. A dissertation on Bend development history by Hugh Roe Davison at University of Oregon filled in some gaps related to irrigation in the area, without which a ranch would not have been possible. Most importantly, personal conversations and oral history interviews conducted with former resident Sharron Matson Rosengarth, and her husband Tony Rosengarth, were helpful in gathering stories about the house as a museum, the two main families that lived on the ranch and the shared collection kept in both the home and tack shed.

\footnotetext{
${ }^{190}$ Davidson, 71. Note: The Carey Desert Land Act was enacted in 1894 but modified in 1896 and again in 1901. The act allowed the government to contract private companies to build canals and irrigation systems, then sell water rights to residents.
} 
Duberow included a key list of deed transfers, which provided information on early ownership and use of the property. The original parcel was first patented by the State of Oregon via deed from the federal government in 1908, which "coincides closely with the availability of water supplied by the Deschutes Irrigation and Power Company" and the beginnings of the incorporated city. ${ }^{191}$ For the first two years, the land was leased by the state to an investor named J.H. Bean, but there is no evidence that he actually lived on the land. ${ }^{192}$ Two references hint at an identity, the first as the owner of the J.H. Bean Building on Wall Street, which was built in 1912, had a water-powered elevator and was one of the first structures in Bend made of local brick and volcanic tuff. ${ }^{193}$ The second set of records mention Bean in land deeds that are digitized and accessible online by the Deschutes County Public Records Center. ${ }^{194}$ They pertain to several transfers to and from J.H. Bean and John F. Bean, both unmarried men, with outside parties. The two were likely family, but the exact relationship is unknown. However, it is clear they were investment partners, and a few notes hint at irrigation and ditch work on various tracts that they owned.

The first actual sale of the ranch occurred in September of 1910, from the State of Oregon to Frank C. Rowlee, general manager of the Deschutes Irrigation and Power Company, which had been drilling holes up to "1000 feet each" deep, to look for water

\footnotetext{
${ }^{191}$ Bernard G. Duberow, History of Hollinshead Park (Formerly Timberlane Ranch): From the time of Original Settlement Through the Complete Acquisition Process for Development as a Park, Deschutes County Historical Society Archive (Hollinshead file), 10/08/1985 (revised), pp.2 (pp.3 on the scanned PDF).

192 Duberow, 4-5.

193 “Peter Byberg House,” National Register of Historic Places Nomination Form, Nov. 28, 1998 (Accessed April 2021). Link: https://www.bendoregon.gov/Home/ShowDocument?id=6195 ${ }^{194}$ Deschutes County Public Records Center, Search results for land deed records for J.H. Bean (Accessed April 2021). Link: https://weblink.deschutes.org/Public/Welcome.aspx?dbid=0\&repo=LFPUB
} 
around the region and build canals. ${ }^{195}$ Within weeks, Rowlee flipped the property and sold it to a forty-five-year-old widow from New York named Ada R. Johnston. ${ }^{196}$ The 1910 United States Census notes that she lived on the ranch with her single daughter, Helen Johnston and elderly father-in-law, Samuel Johnston. She also had an unemployed boarder named Cora Jones, whose son George Allen Jones married Helen Johnston in 1917 and the young couple bought the land. George Jones likely knew the first owner (Rowlee) because he worked as a timekeeper for the Deschutes Irrigation and Power Company. George and Helen Jones would eventually be "regarded as the first pioneer[s] who actually lived on the property" and the road along the west perimeter of the modern park is named for the family. ${ }^{197}$

The Joneses built the original homestead house and the tack shed by 1920, also working together to raise sheep and farm crops. ${ }^{198}$ In 1922, George Jones became paymaster at the Brooks-Scanlon Lumber Company, one of two famous sawmills that contributed to the early history and growth of the city of Bend. ${ }^{199}$ At that time, George and Helen Jones transferred the ranch back to Ada Johnston, and then tragically the husband and wife both passed away in July of 1924, the former by car accident and the latter committing suicide in the aftermath. ${ }^{200}$ Grieving for not only her late husband, but now her daughter and son-

\footnotetext{
195 “Interior Canal Work," East Oregonian (Pendleton, OR), March 02, 1905.

Newspapers.com link: https://www.newspapers.com/image/174326776/?terms=F.C.\%20Rowlee\&match=1

196 Duberow, 3.

197 Duberow, 3.

198 The exact year that the house and tack shed were built is unknown at this time, but it is known that the Jones family lived in it.

199 Duberow, 3.

200 "Car Wreck Caused by Speeder Ends Lives; Mrs. George Jones Unwilling to Survive Husband," The Bend Bulletin, July 10, 1924. Accessed on April 20, 2021. Newspapers.com link: https://www.newspapers.com/image/94799317/?terms=George\%20Jones\&match=1
} 
in-law, Ada Johnston continued to own the ranch for five more years, but lost it to the Deschutes County Sheriff in the fall of 1929. Coincidently, the stock market crash occurred at the same time and while it is unclear if that is the direct reason, the government nevertheless took the property "due to non-payment of taxes."201

The county once again sold the homestead in 1930, but this time to the Union Central Life Insurance Company. The Depression came into full swing and because no one could afford to invest at that time, the ranch became a "Deschutes County experimental farm." ${ }^{202}$ The Works Progress Administration noted that experimental farms ranged "from 30 to 200 acres" and were specifically designed to aid in agricultural and industrial development. ${ }^{203}$ The goal was to gather scientific and statistical data by testing new feeding and breeding procedures, crops, pesticides and irrigation systems. The Orchard District itself was one of those experiments, and the University of Oregon planted fruit trees between the west side of Bend Parkway and the east face of Pilot Butte (on portions of the original ranch). Most of the orchards failed due to late spring frosts, but there are still some fruit trees scattered throughout the neighborhood today. It is unclear what the exact relationship between the insurance company and the county was in terms of experimental farming, but the property was briefly leased to two different farmers, T.H. Foster in 1936 and then R.N. Broughton in $1938 .^{204}$

\footnotetext{
201 Duberow, 3.

202 "Plans Told for Housing Development," The Bend Bulletin, Bend, Oregon, July 20, 1959 (Newspapers.com: Accessed April 2021).

203 The WPA Guide to 1930s Iowa (Federal Writers Project: University of Iowa Press, 1938), 178.

${ }^{204}$ Duberow, 3. More research needs to be done on the stories of T.H. Foster and R.N. Broughton to find out their relationships with experimental farming, Deschutes County, and the Union Central Life Insurance Company.
} 
Beginning in 1939, Dean and Lily Hollinshead purchased what they dubbed

Timberlane Ranch in two tracts, finalizing the deal with Union Central Insurance over the next five years. ${ }^{205}$ On their new ranch, the couple grew crops and raised Tennessee Walking horses, along with cattle, pigs, chickens, and other domesticated animals, which enabled them to live off the land. Dean had moved as a toddler to Bend around 1901, with his parents William and Ella May Hollinshead. The family lived in a log cabin at first and they would pack up a wagon and travel to Independence every summer to camp and pick hops together, as Oregon was a global producer of the crop at that time. Dean and two older brothers later learned the value of hard work raising and branding cattle for the local Stearns outfit. In 1924, Dean started a freight business, running mail and passengers over dusty summer roads and deep winter snow between Bend, La Pine and Silver Lake, while one of his brothers did the southern route to Lakeview, Oregon. ${ }^{206}$ After Dean bought Timberlane Ranch, he ended the freight business, but remained "partners in contract logging" with his brother Cecil until 1953. ${ }^{207}$

Lily B. Hoard was born in Minnesota in 1895 and went on to earn a master's in education from her home state. For a time, she taught in a saloon that had been converted to a schoolhouse in Eagle Creek, Montana, stating that she had "used a gambling table" as her desk. ${ }^{208}$ After moving to Oregon in the 1920s, she taught in the Langlois, Silver

\footnotetext{
${ }^{205}$ Again, information on purchase is listed in Bernard Duberow's report, under the list of deed transfers for Hollinshead Park.

206 The information about Dean Hollinshead and his early family life was gleaned from two copied family histories in the Hollinshead archival file at DCHS, with unknown authors. There are several stories about Dean, his freight business, what life was like on the farm and other early family memories.

207 "Long Resident of the Area Dies," Obituary for Cecil Hollinshead (1898-1956), Bend Bulletin, May 25, 1956 (Hollinshead file: Deschutes County Historical Society, Bend, Oregon), Accessed August 2019.

208 "Teacher Retires, Will Teach Horses Instead of Children," Unknown Newspaper and date (Hollinshead file: Clackamas County Historical Society, Oregon City, Oregon).
} 
Lake and Redmond school districts for many years. Lily and Dean met and married in 1932 and after seven years of saving up money, she was able to retire from teaching to devote all her time to their new ranch. She was very active as a 4-H leader "specializing in horse projects and conservation," and they were both members of the Deschutes County Historical Society and the Deschutes Pioneer Association. ${ }^{209}$ All accounts report that she was one of the toughest horsewomen in Central Oregon. The Bend Bulletin noted that she and Dean had stepped out into the pasture one evening at dusk, when some "frightened horses lunged into her, knocked her down, then trampled her," breaking a rib and collar bone, along with other bruises and contusions. ${ }^{210}$ After a few weeks of recuperation, Lily promptly left the hospital, went back home, and continued the neverending work of riding fences, breaking horses, and rounding up cattle.

Dean and Lily Hollinshead began raising and training horses on the south forty acres of their property, but quickly struck up a friendship with a second couple, James and Virginia Matson. Soon the group made a "sharecropping deal" to farm the other one hundred and twenty acres, which would make it a fully working ranch and help Dean and Lily to pay off Union Insurance. ${ }^{211}$ The idea of sharecropping seems strange on the surface, as it conjures visions of oppressive farming culture in the American South postCivil War, but curiously the practice resurfaced in a different way during the early Depression era of the 1930s. Apparently, poor farmers could work their way up a

\footnotetext{
${ }^{209}$ Obituary, "Lily B. Hollinshead," July 23, 1990 (Hollinshead file: Bend Park and Recreation District, Bend, Oregon, Accessed Summer 2019).

210 “Mrs. Hollinshead Injured at Ranch," The Bend Bulletin, December 12, 1950 (Hollinshead file: Deschutes County Historical Society, Bend, Oregon), Accessed August 2019. ${ }^{211}$ Sharron Matson Rosengarth, Little Country Girl: Stories \& Memories of Life at the Hollinshead Ranch (Booklet: Bend Park \& Recreation District, Bend, Oregon), 1.
} 
"tenancy ladder," from sharecropper to tenant farmer to cash farmer, whereby they would gradually accumulate capital and supplies and eventually purchase their own land. ${ }^{212}$

To get back on their feet, migrant families leaving the Dust Bowl made deals with established landowners in the west to rent acreage as tenant farmers, providing their own tools, equipment, seed, and animals, and paying a portion of the crops back as payment. However, many did not have that ability because they had lost everything, so they planned to work their way up to tenant farming by sharecropping first, where the landowner provides the equipment and animals and takes a larger portion of the profit. Just like sharecropping in the South though, the problem remained that "thousands of farmers fell down the tenancy ladder rather than moving up."213

It is unclear as to the level of tenancy that Jim and Virginia Matson were performing at in the beginning, but the so-called sharecropping deal that they made with Dean and Lily Hollinshead never had negative connotations in historical accounts. Instead, the two families lived and worked together, and helped each other prosper. After ten years, the Matson's were able to buy and lease other properties and provide a future for their children. Their story seems to be an interesting and rare case of tenancy success, as they started out sharecropping under the land (and equipment) ownership of Dean Hollinshead in 1939 but eventually became fully independent. The Matson family were lucky participants in an old system of sharecropping and tenant farming that "ended abruptly

\footnotetext{
${ }^{212}$ David E. Conrad, "Tenant Farming and Sharecropping," The Encyclopedia of Oklahoma History and Culture, https://www.okhistory.org/publications/enc/entry.php?entry=TE009 (Also see: Conrad, David E.,, The Forgotten Farmers: The Story of Sharecroppers in the New Deal (Urbana: University of Illinois Press, 1965).

${ }^{213}$ David E. Conrad, "Tenant Farming and Sharecropping," The Encyclopedia of Oklahoma History and Culture, https://www.okhistory.org/publications/enc/entry.php?entry=TE009
} 
during and after World War II," due to government programs and mechanization. ${ }^{214}$ The story may have been very different had they stayed in the Midwest or moved to urban areas.

Jim and Virginia Matson drove a Model-A Ford to Oregon from Kansas in 1937 because "times were very tough" during the Depression and soon Jim's family members followed them to Bend as well. ${ }^{215}$ The couple had one son at the time and eventually had four more children after they moved into the tiny one floor homestead house on the Hollinshead property. Jim Matson also built a small shack for his elderly parents and put up one brother in the bunkhouse section of the tack shed, also reserved for field laborers. Responsibilities are always dynamic on a ranch, but everyone usually had standard jobs to accomplish every day. Jim and the fieldhands took care of the livestock and farmed various crops like grain, hay, alfalfa, and potatoes, which they sold for feed and to local stores and restaurants.

Virginia Matson milked thirty dairy cows twice daily and sold milk to the Bend Dairy, while also providing garden vegetables and orchard fruit to Erickson's store in Bend. Along with help from her mother-in-law, Virginia also cooked for the family, took care of the five children, sewed clothing and quilts, canned for winter food storage, and even raised geese and plucked the feathers to make mattresses. ${ }^{216}$ By 1950 , Jim and Virginia Matson had earned enough farming on the Hollinshead property to buy their own forty acres nearby on Neff Road, which runs along the "northeast side of the base of Pilot

\footnotetext{
${ }^{214}$ David E. Conrad, "Tenant Farming and Sharecropping," The Encyclopedia of Oklahoma History and Culture, https://www.okhistory.org/publications/enc/entry.php?entry=TE009

215 Rosengarth, 11.

${ }^{216}$ Rosengarth, 8, 12.
} 
Butte. ${ }^{217}$ No longer having to be sharecroppers or tenants to anyone, the family started the Hidden Valley Dairy and remained lifelong friends and neighbors to Dean and Lily Hollinshead.

Beginning in 1956, as local residential development in the Orchard District of Bend became a reality and the larger homestead became increasingly difficult to maintain on their own, Dean and Lily Hollinshead began to reduce their holdings and sell to "subdividers." ${ }^{18}$ They sold one hundred and ten acres to Kerr Realty to develop the Mountain View Estates neighborhood and retained forty as their own retirement nest. As they aged, the couple sold a few smaller sections and made plans to ensure that the last sixteen acres of their beloved Timberlane Ranch went to Bend Park and Recreation District, to see the creation of a what is now Hollinshead Park.

Lily Hollinshead originally had the idea to donate their remaining acreage to the park district while she was attending the opening ceremony for nearby Stover Park in 1969, a two-acre parcel that had also once been part of their original property. She was there to attend the event and speak about the property history, but also struck up a conversation with Governor Tom McCall and BPRD Director Vince Genna about donating Timberlane Ranch. This a conversation confirmed in news accounts, BPRD letters and Bernard Duberow's report on property history. ${ }^{219}$ After that day at the newly christened Stover Park, Vince Genna fostered a close relationship with Dean and Lily Hollinshead, which was probably one reason why they felt comfortable moving forward with a deal. Shared

\footnotetext{
${ }^{217}$ Rosengarth, 1-2.

${ }^{218}$ Duberow, 4-5.

${ }^{219}$ Duberow, 5-6.
} 
intentions for the property were to keep the land beautifully maintained for locals to enjoy, to honor ranching and sharecropping history, to create a house museum and provide educational programming to visitors and tourists.

Between 1974 and 1983 several challenges impeded plans, as BPRD could not fund the purchase of the entire remaining sixteen acres and a "misunderstanding, concerning estate problems, unfolded" between all parties. ${ }^{220}$ Dean and Lily had no children and still wanted to donate property, but needed to retain a fund that would "guarantee them security for their remaining years." ${ }^{221}$ In 1982, neighbors George and Shirley Ray stepped in and purchased five of the acres to hold in trust until BPRD could figure out a plan for the whole property. The park district was able to successfully apply for a grant, which awarded eighty thousand dollars from the Heritage Conservation and Recreation Service (a bureau of the Department of the Interior) to repay George and Shirley Ray and take over that final portion. ${ }^{222}$ Once the BPRD took possession of the eleven and one half acres, and the purchase of the north five acres was finalized, the organization held a dedication ceremony honoring Dean and Lily Hollinshead and their generous donation. On May 28, 1983, over seventy people came to celebrate with a large picnic at the newly christened Hollinshead Park, including staff, friends, family, and local residents. ${ }^{223}$

James Matson was the first of the group to pass away, followed by Dean Hollinshead in November of 1983, just a few months after the park opened. Lily Hollinshead moved to a retirement home until her own passing in 1990, so it remained the responsibility of

\footnotetext{
${ }^{220}$ Duberow, 6-7.

${ }^{221}$ Duberow, 7-8.

${ }^{222}$ Duberow, 8-9.

${ }^{223}$ Duberow, 10.
} 
Virginia Matson and her children to work with the park district to preserve the history of the ranch and the family collections. However, the original homestead house sat empty and continually deteriorated, until one of the Matson children approached the park district to rectify the situation. Sharron Matson Rosengarth, who was born in the "little red house" and lived there until she was ten years old, became instrumental in the effort to save it along with her husband, Tony Rosengarth. ${ }^{224}$ In 1995, the park district renovated the Hollinshead barn into a beautiful rental space, but Sharron could not bear to see her childhood home sit bare and falling into disrepair. She wanted to honor Dean and Lily Hollinshead's plans to create a house museum, as well as her own parents' history as sharecroppers who actually lived in the house and teach the public about ranch life in Bend.

After some negotiation, restoration of the home began on August 8, 1997 with funding for materials and limited labor provided by BPRD, but the Rosengarth family largely did all the work. ${ }^{225}$ Tony Rosengarth tackled the outside of the house first, replacing the roof and siding, front and back porches and many of the old window frames, while also repainting the house brown, rather than the original red. Inside the home, they demolished all modern add-ons (post-1940), sanded and stained the hardwood floors, replaced kitchen counters and restored original appliances. Sharron worked on the interiors and staged the house with Matson family belongings, as close to her childhood memory as possible.

\footnotetext{
${ }^{224}$ Rosengarth, 1.

${ }^{225}$ Letter from the office of Carrie Whitaker, Executive Director of BPRD, ORPA Volunteer Service Award nomination for Sharon and Tony Rosengarth, 1998 (Bend Park and Recreation District: Bend, Oregon, Accessed August 2019).
} 
The Rosengarth's also staged the tack shed, half as the original bunkhouse and half as storage for blacksmith tools and iron implements (like horseshoes), tack equipment, dairy machinery, and two beautifully restored buggies. Sharron and Tony Rosengarth won BPRD's Volunteer Service Award in 1998 because they had spent “over 900 hours of service to the district" in completing restoration work on the house. ${ }^{226}$ They honored Sharron's mother, Virginia Leeds Matson by bringing her to see the finished product on her eightieth birthday in 1999, where they "celebrated with family and friends" in the restored barn. ${ }^{227}$

Ten years later, Bend Park and Recreation District added a new roof to the tack shed, as well as insulation, heating, and electricity for modern use. The homestead house already had water and electricity was added when they did the tack shed, but there are still no restrooms inside the home, which presents a problem for staffing it as a museum in the future. However, the community garden has a modern outhouse that is well maintained and available for public use, just a short walk across the parking lot. After all the above improvements were completed, the barn was rented for events, while Sharron and Tony provided summer tours and educated school groups at the house and tack shed. The couple also held an annual holiday open house for many years, putting up family Christmas decorations, giving tours and handing out homemade cookies and apple cider. Sharron eventually compiled a booklet called Little Country Girl about the history of the

\footnotetext{
${ }^{226}$ Letter from the office of Carrie Whitaker, Executive Director of BPRD, ORPA Volunteer Service Award nomination for Sharon and Tony Rosengarth, 1998 (Bend Park and Recreation District: Bend, Oregon, Accessed August 2019).

${ }^{227}$ Rosengarth, 2.
} 
ranch in the 1940s, which the parks district published, and copies are available to house museum guests and at the historical society.

Due to age, Tony and Sharron Rosengarth eventually slowed and stopped doing school tours, and the house remained closed when they were not available for individual walk throughs. For the last decade, the sign in front of the house at the park provided a number to call for a private showing with Sharron, but visitation has remained very low with only one or two small tours each summer. Part of the new plan to reinterpret the house is for Sharron to participate as a stakeholder by helping with historical facts about the families and collection, as well as the restaging of rooms and creating a self-guided tour program. Being closely involved in the process, rather than shocking her with a finished product which she had no voice in creating, will help her to feel safe and excited to hand over the reins to Deschutes County Historical Society in perpetuity.

During restoration in the late 1990s, Sharron Rosengarth did an interview with the Bend Bulletin and noted that after the Hollinshead property was first donated, the old homestead house had been "left empty as other areas of the park were developed." 228 Despite the work completed by the Rosengarth's in 1998 and the improvements made by the park district in 2009 through 2011, Hollinshead-Matson Homestead House and Tack Shed sat invisible in plain sight. At the same time, the community garden grew, the barn became one of Bend's most popular event spaces, and the landscape remained a carefully maintained and manicured residential park.

${ }^{228}$ Michelle L. Klampe, “Making a House a Home,” Bend Bulletin, about 1998. This clipping is in the Hollinshead archival file at DCHS. 


\section{Rethinking the Hollinshead-Matson Historic House and Tack Shed}

\section{In 2019, Kelly Cannon-Miller with DCHS, along with BPRD Community Relations} staff Julie Brown and Kim Johnson, created a Memo of Understanding (MOU) to "facilitate future interpretive use of the Hollinshead facility and inform a long term care plan through the use of an intern." 229 According to the MOU, initial "desired outcomes," included a full inventory of the house and tack shed, with a detailed spreadsheet and photographs of every object. Corresponding accession numbers would be assigned to each artifact, to be used for easier cataloging at the historical society. Additionally, the intern would work with Sharron and Tony Rosengarth to document the "history associated with objects. ${ }^{" 230}$ The reports generated by the inventory project were used to apply for grant funding, which was awarded and provided necessary materials to move forward with collections preservation and the restaging of each room of the house.

Interning with Kelly Cannon-Miller at DCHS was a good opportunity to leave the city of Portland and stay at a cousin's horse ranch near Bend for that month of August 2019, while conducting fieldwork at Hollinshead Park. Helping on the family ranch and riding horses around the countryside provided an immersive experience while researching the Hollinshead property and Bend history. Furniture and other artifacts covered almost every surface of the small home, so I started in one corner of the living room, moved

\footnotetext{
${ }^{229}$ Memo of Understanding, Bend Park and Recreation District and Deschutes County Historical Society, refers to project at Hollinshead-Matson Homestead House and Tack Shed, dated May 2, 2019 (Emailed from Kelly Cannon-Miller at Deschutes County Historical Society, Accessed August 2019).

${ }^{230}$ Memo of Understanding, Bend Park and Recreation District and Deschutes County Historical Society, refers to project at Hollinshead-Matson Homestead House and Tack Shed, dated May 2, 2019 (Emailed from Kelly Cannon-Miller at Deschutes County Historical Society, Accessed August 2019).
} 
from left to right all the way around, and then adapted the same technique to each additional room. I photographed furniture largely in place, but carefully moved smaller objects to the dining room table for better lighting and then placed each back in original position when finished. Images were captured using my personal iPhone, then airdropped directly onto my laptop, renamed with an accession number, and stored in an organized file labelled "HHH." ${ }^{231}$ The process became faster and more efficient with each passing day of work and a total about one thousand objects were cataloged at the house and in the tack shed combined.

The ideal situation would have been to have Sharron Rosengarth at the site every day, identifying objects as they were cataloged, but it soon became clear that it would have been incredibly time consuming and not necessary or ideal for the limited hours. Instead, Sharron came to the house once, to initially meet and talk about the project, then a second time to film in the main bedroom and sitting at the dining room table, where she spoke about objects displayed throughout the house. Eyes sparkling with memories, Sharron opened on camera about family life on the ranch throughout the 1940s, identified many artifacts that had special meaning and answered questions about the restoration and items with unclear use or provenance. It was touching to hear the love in her voice, as if she was transported back to that time, which made the work more special. Now that the inventory spreadsheet is completed and accessible, she and DCHS staff can take their

\footnotetext{
${ }^{231}$ Images were saved as JPGs at 1200 dpi resolution. Each image number corresponds with the same number in the Excel inventory spreadsheet provided to DCHS \& BPRD. Accession numbers were based on a 2019.0001.0001 system, being catalog year, collection number, set number, and item number. If there is only one object, the set number is eliminated. This is the basic accessioning system used by most modern museums and/or in the software catalog Past Perfect 5.0.
} 
time filling in informational gaps for each object and then have volunteers or interns transfer the inventory into the museum storage and database.

After cataloging about seven hundred and fifty artifacts in the house, I moved on to the tack shed, where I inventoried anther two hundred and fifty objects related to ranching, farming and blacksmithing. ${ }^{232}$ During this period, Tony Rosengarth spent a day identifying machinery and tack materials. While he was available and willing, I took several short videos of him talking about the restoration on the house and shed. Tony seemed endearingly gruff and quiet at first, but he soon stepped into his element and happily spoke about all the different blacksmithing tools, dairy machinery, horse tack equipment, a black 1895 doctor's buggy and his "pride and gem," a fully restored green and white surrey with a fringe on top. ${ }^{233}$ Sadly, that was the last video taken of Tony as he passed away just a few weeks later, which brought home the importance of gathering oral histories from those willing to give their time and honoring their contributions to local historic preservation.

I conducted one day of research at Deschutes County Historical Society, where I went through a single file of scanned written histories (including Duberow and Davidson), photos, and newspaper clippings about Hollinshead Park. Information was limited, which was not surprising, and a search of the Past Perfect 5.0 database did not turn up many

\footnotetext{
${ }^{232}$ The inventory list on the Excel spreadsheet provided to project partners (DCHS \& BPRD) has exactly 1,042 items cataloged. Objects are itemized by number, but organized by group, due to the method of going through one room at a time. Tack shed materials take up the last quarter of the list. Each entry is organized by accession number, object name, corresponding photo number, and other identifiers, like description, dimensions, and provenance (if known at that time).

${ }^{233}$ Liza J. Schade, “Hollinshead Homestead House,” Created Fall 2019. Posted online June 9, 2020. YouTube Link: https://www.youtube.com/watch?v=s_VHcfdhxCk
} 
scanned images or other useful records. There were maps of the county available, but nothing that showed the original government owned property specifically. In the last week of the internship, Kim Johnson opened the archive at the Bend Park and Recreation District, supplying two banker boxes containing several binders of Hollinshead records. One binder contained letters and documents related to the decade long acquisition of the sixteen acres by BPRD finalized in 1984, while other binders held original photographs of Dean and Lilly Hollinshead and the only map of the park, plus many news clippings and other ephemera.

From the start, it was clear that in addition to the assigned inventory project, a broader site assessment should be completed, which could help the partners (BPRD and DCHS) to see what issues needed solutions. This was not required, but as a professional public historian I deemed it prudent to complete one. The final report submitted to all parties provided a short history of the property based on archival sources, outlined the goals of the internship, and the method of inventory, research and video creation followed throughout the project. Most importantly, the report assessed the exterior of the house for safety needs and ADA accessibility, then detailed challenges for collections preservation and restaging of each room of the house and tack shed. Finally, recommendations were given as to how to accomplish those next steps.

A key element of being a public historian today is to use "practical working formats" that reflect digital developments in the field. ${ }^{234}$ On top of the assigned work and supplemental assessment, I wanted to produce a video asset for the two organizations to

\footnotetext{
${ }^{234}$ Douglas A. Boyd and Mary A. Larson (Eds.), Oral History and the Digital Humanities: Voice, Access, and Engagement (Palgrave McMillan: New York, 2014), 5.
} 
post to their websites and social media, that would educate the public about the history of the park and raise awareness about preservation. This immersive project provided a perfect opportunity to be creative, after the required hours at the site and the inventory were finished. Some of the stories the Rosengarth's told were amazing, like when Tony stripped the roof and found tin sheeting printed with advertisements for the local Greenwood area in Bend. Sharron talked of cold winters without electricity, her parents growing crops and working with the cattle, and family Christmases and the heirlooms kept by her mother over the years, among other topics. Over the fall of 2019, I produced a six minute promotional video using their filmed interviews, narration based on archival research and historic images, and created a YouTube link which was shared with the partners for easier posting. The video provided a history of the house, with Sharron's memories of living on the farm, and honored the work done by her and Tony to restore and provide tours of the property. ${ }^{235}$ After the sad passing of Tony, Sharron was moved to see that I dedicated the video to him and seemed determined to continue working with the partners on the reinterpretation project. She wanted to ensure that the house will eventually be open to the public regularly, but also that the museum and park district have the information needed to be accurate, as well as respectful and dedicated to continued care and maintenance.

The work of doing the inventory was a little intense due to time constraints and therefore quicker in process than it would be in a professional museum environment. That

\footnotetext{
235 Liza J. Schade, “Hollinshead Homestead House,” Created Fall 2019. Posted online June 9, 2020.
} YouTube Link: https://www.youtube.com/watch?v=s_VHcfdhxCk 
said, it was personally fulfilling to discover a more comprehensive history of habitation, reshaping and development. As a visual thinker, I enjoyed imagining new ways to interpret the various narratives that emerged, as well as being immersed in the physical collections. I even discovered a few objects that I had not seen when working with collections before and made many posts on personal social media that inspired a lot of curiosity, memories, and fun responses from my network.

The best part of the internship was spending time with Sharron and Tony Rosengarth, who were generous, trusting, and willing to share their vast knowledge. It was also an honor to work under Kelly Cannon-Miller, Julie Brown, and Kim Johnson, helping the team to complete the first step of their reinterpretation plan and giving them advice on how to move forward. The inventory, site assessment, and video were all beneficial components of the internship because the project partners used them to promote the site and apply for the Oregon Heritage Grant. Awarded in December 2019, the funds made possible the next steps to organize and preserve the collection and restage the house to be less cluttered by removing duplicate and deteriorating items. I also made recommendations to remove a crab apple tree next to the front door, to install a concrete walkway and wheelchair ramp up to the front door of the house, reinterpret the narrative and re-curate the entire presentation, as well as create future educational programming connecting the house with park guests. 
Factors that Affect the Hollinshead-Matson Historic House \& Tack Shed

The plan that Dean and Lily had to save their ranch as a park and historic site was inspired by activism post-National Historic Preservation Act, even though the property was not bequeathed to the park district until 1983. The historic house and tack shed have enormous potential for improved public access today, due to the easily accessible and beautiful park location, a regular visitor base and already restored buildings. Kim Johnson is a cooperative park liaison and Kelly Cannon-Miller is providing museum experience and historical knowledge about Deschutes County, which will be beneficial to promoting the site and re-interesting the diverse public. Additionally, Sharron Matson Rosengarth is an open and dedicated volunteer who has and will continue to provide invaluable information and memories about the two families, with a personal stake in the legacy of the house and history of the park.

The partnership established an overall methodology for implementation step by step, starting with initial planning. I completed the initial inventory of the house and tack shed, which allowed the partners to move on to collections preservation and research, reimagining the exhibition and self-guided tour. Full reinterpretation may yet prove to be challenge, but possibilities for the presentation of many overlapping narratives is entirely possible. It will be important to research and connect Hollinshead Park to historical accounts that will interest the public and promote a new outlook on the diverse identities that make up Bend (and Oregon) history. 


\section{Methodology at Hollinshead-Matson Historic House \& Tack Shed}

In the past, all parties involved in saving this park intended to create a museum in the homestead house but getting to that point meant doing repairs and restoration first, which took time and money to accomplish. Dean and Lily Hollinshead did not want to glorify themselves and their own personal prosperity. Instead, they wanted to help preserve Bend history and remind future residents of the legacy of ranching that was slowly being left behind, as city and residential development spread around them. Their biggest goal was not necessarily to interpret the house itself, but to donate the remaining parcel to the district and get the park designated before they passed away, which they were able to see happen in 1983. Bend Park and Recreation District did what they could to finance those last sixteen acres and George and Shirley Ray helped with that transaction, as Timberlane Ranch had also been special to their own lives as long time neighbors.

After the barn was renovated in 1995, it brought in revenue for the park, therefore no special plans were put in place for the house and tack shed to be converted into a museum site. Tony and Sharron Rosengarth became pivotal in pressing the park district to restore the house and tack shed, without whom neither structure would likely be left standing today. Had it not been for their efforts, the structures would have remained deteriorated and probably been torn down by BPRD, like what occurred with Dean and Lily's home on top of the hill. Thankfully, the work done by Tony and Sharron Rosengarth on the exterior and interior, donation of time for tours and money for continued maintenance and repairs, plus their consistent pressure to do more improvements in 2009, made the current project to reinterpret the house and tack shed entirely possible now. 
As in the previous chapter, current methodology at Hollinshead-Matson Historic House and Tack Shed refers to the full reinterpretation of both buildings. The first step of this project was building the partnership between park district and historical society and finding an intern to do a full inventory. As a graduate student, I completed that goal in summer 2019 and the inventory, assessment, and video were used by the partners to apply for grant funds, which were awarded to further preserve the site. Inventory was simple in process, using phone images and an Excel spreadsheet, while in a museum environment, a more expensive camera and lighting set up would have been used, as well as Past Perfect 5.0 software for cataloging. However, the work was done quickly using the former method and the data was transferrable to the latter inventory system at Deschutes County Historical Society.

The next step of the reinterpretation process is to restage each room with a cleaner look that allows people to comfortably walk through and focus on, touch, and use specific items. For example, all historical documents and photos related to the families were removed to society archives in summer of 2020 and will be scanned (and/or transcribed) into their database and used for researching new narratives about the property. Old deteriorating display cabinets will be taken off the walls, as well as removal of all the mannequins in the house, fake plastic food in the kitchen and duplicate items, like Singer sewing machines, radios, and trunks. A minimal look does not mean leaving rooms completely bare. Each room should be simply curated, but also feel like a warm home and allow for people to connect with important items, like the wood stove, ice box, 
laundry and canning equipment, toys, and books, as well as women's clothing and recipes.

Clearing the walls of damaged framed images that do not relate to the family will make space for Kelly Cannon-Miller to write and hang up new interpretive text and image panels that represent a continuous and contextual narrative of the history of the property. Initial research has already revealed several previously unknown or ignored aspects, which broaden perspectives about the land and how it has been shaped over time. Hollinshead Park history includes Warm Springs habitation, Bend growth and irrigation expansion, and early property ownership. There are many stories about other people connected to this parcel that have been ignored, who were just as important as the Hollinshead and Matson families and who also made an early footprint on the land. Educating visitors about lifeways of ranching and sharecropping for all members of a family would demonstrate that men, women, children and fieldhands worked together to make a farm function and prosper. Like most ranches, Sharron Matson Rosengarth noted that "everyone had a job to do," contributing equally to the never-ending chores and improvements that had to be done. ${ }^{236}$ Lily Hollinshead and Virginia Matson were equal partners and laborers with their husbands and the Matson children also had daily duties, like milking cows, picking rocks and pulling weeds, watering and caring for the garden, cooking for the field hands and canning vegetables for their large storage cellar north of the house.

${ }^{236}$ Rosengarth, 4. 
Interpretation should also expand to include a narrative about Hollywood movie creation in Central Oregon in the 1950s, as Dean and Lily often offered up their property, provided horses and rode as extras in western movies. Films like "The Indian Fighter" with Kirk Douglas clearly contributed to creation of Wild West mythology in popular media, and this movie portrayed a former solider protecting a wagon train from Sioux warriors who traded gold for whiskey. Douglas' film company, Byrna Productions, worked with the City of Bend and the U.S. Forestry Service to construct a fake fort at Benham Falls. They hired Dean and Lily Hollinshead, along with "200 Warms Springs Indians and scores of extras" to ride horses and wear feathered headdresses in the background ${ }^{237}$ However, only white actors were allowed to play speaking parts in Hollywood in that era and white extras were paid much more than tribal members and other minorities.

Addressing contemporary residential development and how people use the park today will help connect guests to recent history, gain awareness about saving historical properties and inspire them to get involved and contribute their own perspectives. Sharron and Tony Rosengarth did an immense amount of work to save the house and make it into a museum that people could tour through. They also had some proprietary feelings towards the property and seemed resistant to change on the current project, or even a little unaware as to what would happen to the collection and displays. The relationship between the couple and the park district seemed a little strained in summer of 2019, as the Rosengarth's commented that they could not get approval from the district to

${ }^{237}$ Jack Ling, "Kirk Douglas in Bend for Film," Bend Bulletin, May 21, 1955, Historic Oregon Newspapers, Downloaded May 20, 2020). 
build an add-on to the tack shed, which could be used to store and display a third wagon. Also, Sharron curated the presentation of the house and tack shed, so she was not in a hurry to watch historical society staff and volunteers going through her family belongings, boxing, and taking away items, or changing the set up. While it is important to address the clear issues of a cluttered and unclear presentation, it is also crucial not to make Sharron feel overwhelmed or insulted by the changes to narrative and curation. Instead, museum staff should explain decisions to her in a way that helps her understand why they are important and that nothing will be taken away but will instead add to the richness of the story by including new research and perspectives. Sharron Rosengarth wishes to remain involved in the project and it is important that she actively participate with the historical society in the full process of reinterpretation, which should also include her and Tony's own story of restoration and dedication to the site.

\section{Public Access \& Engagement at Hollinshead-Matson Historic House and Tack Shed}

The Hollinshead-Matson ranch has many opportunities for public access and engagement, more than any sites in Oregon that were researched or visited for this thesis. Access in this case refers to the fact that, unlike the Stevens-Crawford site, this is a fully functional and regularly used public park, with visitors coming and going every day from spring through fall. Engagement refers to the need for programming, not only independent to the site itself, like school and self-guided tours, but opening the house during barn events and creating picnics, markets, fairs, and other activities. Taking advantage of those ideas can increase education about the Warm Springs culture, early 
emigrant settlement, family ranching in the early $20^{\text {th }}$ century, irrigation and urban development, and other topics not yet discovered. Until now, the public has missed out on all those connections by allowing the house to remain closed and full of dust and clutter, with creepy mannequins peering out through cloudy windows at frightened children playing in the park.

As an intern at the site in August of 2019, it was not my responsibility to give tours of the house or tack shed, but to complete the specific inventory project and rethink the curation of the house. Due to the heat of summer and having no air conditioning in the house, it was necessary to start work early in the cool morning hours and keep the front and back doors open with a fan running for air flow. I usually had to pack up by four in the afternoon when it became too hot to stay indoors. The sight of an open front door was a lure for curious park visitors, who would either make themselves known and start asking questions or simply sneak up the steps and walk right inside. At first, it was easy to resist and tell them the house was not open. However, it soon became a daily visitation, and many commented that they had been coming to the park for ages and never seen the inside. Eventually, I spent an hour of each day talking to people about what I was learning about the history of the land and families that lived there, as well as what the plans were for reinterpretation of the house and tack shed and improving access. Rather than pushing the public away, the inventory project provided an opportunity to personally talk with people about what they liked and did not like about the site, what areas of the history they were interested in and the types of programming they would like to see in the future. It was a happy shock to see so much interest, which made the 
research more fulfilling and the inventory more pressing to accomplish, so that the partners could move forward with grant applications, collections preservation, research, and restaging.

In the beginning, visitation at Hollinshead-Matson Historic House and Tack Shed was non-existent, with priorities being the creation and landscaping of the larger park in 1983, the opening of the community garden in 1988 and restoration of the barn in 1995. Sharron and Tony Rosengarth's efforts to restore the house (under BPRD permissions and contributions) paved the way for the site to finally be amateurly curated and opened to the public, and they did provide summer school tours and showcased their buggies in annual town parades. However, once they stopped leading those larger groups, visitation dropped to just one or two summer tours and the annual holiday open house.

Now that Sharron Matson Rosengarth is ready to hand over tour and maintenance duties, access will mean training volunteers to open the house for school tours and regular visitation. The site should also be made available to guests that come for weddings in the barn, as part of a ranch package where the bride and groom and their guests can take fun photos, especially sitting or riding in the two beautiful buggies. The house is very small and if properly curated, a short self-guided tour is entirely possible, with volunteers available to answer questions and engage as much as the guest desires. One issue is a lack of a working bathroom, which needs to be addressed if the public is to spend more time there. While the renovated barn has a bathroom for event use and there is a public outhouse at the garden not far away, visitors, staff and volunteers at the house and tack shed should also have easy access to facilities. 
The property location just off Highway 95, which runs north-south through Bend, makes the Hollinshead-Matson site easy to find and parking can accommodate large groups. It is a clean and spacious, pet friendly park, with a lot of places to explore with dogs and room for family picnics. However, there is no walkway from the parking lot to the front steps of the house, only grass which can become slick in rainy weather. A crab apple tree next to the front of the house drops fruit all over the area, including on the steps, which creates a tripping hazard, and the park does not pick them up unless they are asked specifically by Sharron Rosengarth when she does an occasional tour.

Recommendations were made to the partners to take down the crab apple, as it is not part of the historic parcel, and to install a pathway from the parking lot up to the porch. Additionally, the partners need to install an ADA compliant ramp up to the front door, perhaps replacing the steps or adding the ramp on the side of them.

Like the Stevens-Crawford site in the previous chapter, access also means providing information about the site online. Very little data can be found about Hollinshead Park on the web, except for brief one paragraph blurbs that only give basic information about the setting, hours of operation and scheduling wedding events in the barn. Records in the historical society and park district archives show that there is plenty of information that could interpret many narratives. As my six-minute video created for the partners demonstrates, the opportunity is ripe to create various short videos about the history of the site and associated objects. Ideally, an entire page linked to both partner websites could be set up using images, stories, timelines, videos, and even an interactive tour or 
game. Additionally, links to other sites that need support can be included and a donation page for those that want to financially support projects.

Public engagement at Hollinshead-Matson Historic House and Tack Shed is about more than simple self-guided tours. Connecting the house and tack shed back to the barn and original park history is important to helping people understand the entire property, not just portions of it. Hollinshead Park also has continuing significance to their own contemporary lives, which means people should be invited to share their own unique perspectives about the past and participate in decisions about how the land should be conserved in the future. Every season provides opportunities for the public to attend garden parties, put on plays and art shows, provide a local farmers market, hold 4-H and Buckaroo events, conduct school camps, and give out buggy rides in the summers and sleigh rides and hot apple cider at Christmas. Warm Springs tribal officials should be respectfully invited to the park to give blessings, teach the public about their own ancestry and beliefs, and tell stories about Pilot Butte and life in the high desert. Families that have been affected by removal and discrimination over time, and the importance of carrying on generational traditions, should also be addressed.

\section{Board Capacity at Hollinshead-Matson Historic House and Tack Shed}

As an historic site, Hollinshead-Matson Historic House and Tack Shed has benefits that are helping to get the current reinterpretation project accomplished. The initial partnership between the Bend Park and Recreation District and Dean and Lily Hollinshead allowed for the property to be saved in 1983. In that case, the board was 
highly involved because it was a partial purchase and donation of land and the creation of a public park. The current partnership between Bend Park and Recreation District and Deschutes County Historical Society is not a new concept in Oregon. There are other sites that have worked with park districts to accomplish projects, such as the Alvin T. Smith House in Forest Grove. At Hollinshead, the partners are open to new ideas about how to solve problems, willing to put in time and find funding, and work with Sharron Rosengarth to see the space honored and opened to the public.

Under the collaboration, there are two full boards making decisions about the reinterpretation project, as well as future maintenance and programming. The duty of DCHS was to provide expertise from a professional historian in Kelly Cannon-Miller, to hire and supervise an intern to conduct the inventory and "make available" archival material that would help to interpret new narratives about the site. ${ }^{238}$ The duty of BPRD was to apply for grants and fund the paid internship, provide access to the site and introduce the former resident, who would help with historical information about the property and collections. Additionally, BPRD fosters "exceptional park and recreation services" that enrich the community, which means ensuring funding and staff for an open site in the future and working with DCHS to create events and activities that interest the public. ${ }^{239}$

\footnotetext{
${ }^{238}$ Memo of Understanding, Bend Park and Recreation District and Deschutes County Historical Society, Refers to project at Hollinshead-Matson Homestead House and Tack Shed, dated May 2, 2019 (Emailed from Kelly Cannon-Miller at Deschutes County Historical Society, Accessed August 2019).

${ }^{239}$ Memo of Understanding, Bend Park and Recreation District and Deschutes County Historical Society, Refers to project at Hollinshead-Matson Homestead House and Tack Shed, dated May 2, 2019 (Emailed from Kelly Cannon-Miller at Deschutes County Historical Society, Accessed August 2019).
} 
The separate organizations and their individual boards do not necessarily work directly together, but each has missions that support the project. The partners are accomplishing their goals through staff members Kelly Cannon-Miller, Julie Brown and Kim Johnson, who make a great team that listens and compromises with one another and efficiently plans each step of the project. Under DCHS board approval, Kelly Cannon-Miller made historical materials available from the museum archive, supervised the collections work and rethinking of the house, and is now directing research and restaging. Under BPRD administrative approval, Julie Brown and Kim Johnson gave access to the house and parks archival records, introduced me to Sharron and Tony Rosengarth, and will continue to provide any necessary support throughout the "long-term care plan." 240

This partnership is proving to be a successful model in Oregon for how organizations (and private owners) can work with park districts to ensure the future of historic properties and provide a living educational space for the public. The willingness to collaborate and share information, rather than ignore the site or argue about what needs to be done, has been crucial to a working relationship and successful completion of goals. Not all sites are on parks land, so these partnerships may not always be possible. However, the three team members have provided an example for other sites to follow and the reinterpretation of more historic sites like this should be a priority.

\footnotetext{
240 Memo of Understanding, Bend Park and Recreation District and Deschutes County Historical Society, Refers to project at Hollinshead-Matson Homestead House and Tack Shed, dated May 2, 2019 (Emailed from Kelly Cannon-Miller at Deschutes County Historical Society, Accessed August 2019).
} 


\section{Funding at Hollinshead-Matson Historic House and Tack Shed}

Dean and Lily Hollinshead donated the sixteen acre property to Bend Park and Recreation District, but they needed funds to live on during their twilight years. As the district was unable to provide that at first, George and Shirley Ray bought five acres for $\$ 80,000$, which the district later paid to the couple to finally complete ownership in 1983 . This helped Dean and Lily Hollinshead to have comfort and security in their last few years, for the park district to save the property and for George and Shirley Ray to honor their longtime friends and neighbors. The restoration of the barn in 1995 was funded by BPRD's eight percent "park dedication fees" and part of the district budget. ${ }^{241}$ The same year, an urban forestry grant provided money to restore the orchards around the district, but for some odd reason park staff planted pines, maples and the crab apple tree that now needs to be removed. In 1997, when Sharron and Tony Rosengarth asked the park district to restore the house, funds for construction materials were provided, but the couple (along with family and friends) had to do all the labor and clean and repair key artifacts, like the old wood stove and ice box.

In 2000, park district staff Paula Lowery wrote a short history of the property and mentioned that the next project (at that time) was to restore the milk barn. That would provide storage and a display space for ranch implements that Dean Hollinshead had donated, which had been kept in a structure at "at Tillicum Park and will require some restoration. ${ }^{242}$ No milk barn was ever mentioned again, but Tony Rosengarth wrote a

\footnotetext{
${ }^{241}$ Paula Lowery, "Hollinshead History" (Deschutes County Historical Society: Bend, Oregon, May 2000), 7. ${ }^{242}$ Lowery, 8.
} 
letter to Ed Moore at the park district in 2011, congratulating them on "doing an outstanding job bringing the old bunkhouse back to life," which implies that they had funded the restoration of the tack shed. ${ }^{243}$ At that time, Sharron and Tony were able to get Dean and Lily's saddles from the Deschutes County Historical Society to display in the shed. They also brought remaining collections over from the barn and set up the bunkhouse side with a bed and wood stove, mannequins playing cards at a central table, along with other items like hats, blankets, pictures, shaving implements, milk cans, lanterns and washtubs. This building added to the presentation of the house because tours could see how the family lived together, then go out to the tack shed and bunkhouse to find out more about the work of running a ranch and the fieldhands that lived in there.

Funding for the current reinterpretation project was provided by BPRD for the initial paid internship, and the subsequent grant award for collections supplies to start the inventory and preservation inside both buildings. More awards and/or donations will be needed for restaging the house, especially for things like proper storage supplies, mounting materials for new interpretive text panels, installation of a front pathway and ADA wheelchair ramp, addressing the lack of restroom and other needs. When programming becomes a possibility, the partners will have to staff the site and plan carefully to share costs. Both organizations can continue to qualify and apply for grants or provide funds from their separate budgets for continued work on restaging. Many types of fundraising events and opportunities are possible to gain support for tours and

243 Tony Rosengarth, Email to Ed Moore, dated December 12, 2011 (Bend Park and Recreation District), Accessed August 2019. 
school field trips, repairs, and even the creation of a website dedicated to the Hollinshead Park and its history.

\section{$\underline{\text { Conclusion }}$}

Unlike most historic properties throughout the United States, the Hollinshead ranch does not sport a giant white mansion with incredible architecture, and it does not tell the narrative of one prominent man of renown. The Hollinshead property instead represents many stories, from early geology and volcanic eruptions to indigenous cultures, government patents, horse ranching and western movies, and most importantly, sharecropping and family life on a farm. That is a very different and much broader narrative from the mythology of the pioneer that has been attached to the property history over time, especially when no Oregon Trail emigrants ever settled on that parcel, and it was not developed until after the city of Bend was incorporated. However, actions and events that occurred on this property did contribute to the Americanized story of forging a new life out of nothing and to a unique cowboy culture popularized in the 1950s. Most importantly, research at this site opened a complex history of the land and the common family, which almost anyone can connect to or at least empathize with, thus creating a richer experience for tourists and local park visitors.

The partnership created by the park district and historical society has proved to be a successful model for other park districts with historic properties, to make plans with similar organizations and accomplish projects. Professionals like Kelly Cannon-Miller, Julie Brown, and Kim Johnson are acting as team leaders, using their networks and 
expertise to plan and implement changes at the house and tack shed as part of the current preservation movement. With the help of Sharron Rosengarth to provide memories and historical knowledge, interns like myself to conduct assigned projects, and museum and park volunteers to give wherever they can, it is possible to meet the need for increased access and engagement at this site, in which visitors to the park have already shown active interest and curiosity. It will be up to the historical society and park district to continue pushing hard to complete the next stage of the reinterpretation of the homestead house and tack shed, research and restaging. After the house is fully curated, or even during the process, the partners can begin planning for regular open hours and new programming. Opening the house has not been crucial to the future of park use, and therefore has not been a priority until now. However, opening a newly interpreted and curated house to regular operation, and creating fun and interactive events, will increase and enrich public use and financial support. It will also be important to provide information to wider audiences, producing more digital assets about the collections, conducting oral histories with long time locals, and networking with other professionals for advice. The vision is in place and in progress but work still needs to be done to honor the intentions of Dean and Lily Hollinshead, and those of Sharron and Tony Rosengarth. Continued action is crucial to creating a fully functional interpretive site that educates and inspires both adults and children alike. 


\section{Epilogue}

The title and broader theme of this thesis were inspired by Kuri Gill, the Grants and Outreach Coordinator for the Oregon State Historic Preservation Office, who advises that each historic house museum should "find their own niche" within the community. ${ }^{244}$ I contacted her in May 2020 and asked questions about the state of the preservation in Oregon and what organizations need to do to rethink their sites. Gill asserted that, especially in larger cities, house museums need to use outreach on a greater scale to understand the demographics and desires of their community. Staff and volunteers do not need to feel trapped by one narrative, but they can "talk about the house in context of the world it was in," opening to a broader range of perspectives. ${ }^{245}$ Gill also stated that the granting agencies providing financial support want to "make sure their funding is going to achieve results," which is why applications can be competitive and need to be submitted with appropriate histories and project goals, and specific budgets. ${ }^{246}$ It is crucial to execute careful planning prior to applying for grants, but "people will step up" to support a site if they feel well informed and invited to participate. ${ }^{247}$

As her remarks suggest, reinterpretation, building partnerships and serving community needs are top priorities for house museums in Oregon right now. Challenges need to be

\footnotetext{
${ }^{244}$ Kuri Gill and Liza J. Schade, Telephone call, May 2020, Recording and notes located on personal external hard drive.

${ }^{245}$ Kuri Gill and Liza J. Schade, Telephone call, May 2020, Recording and notes located on personal external hard drive.

${ }^{246}$ Kuri Gill and Liza J. Schade, Telephone call, May 2020, Recording and notes located on personal external hard drive.

${ }^{247}$ Kuri Gill and Liza J. Schade, Telephone call, May 2020, Recording and notes located on personal external hard drive.
} 
addressed at all two thousand listed historic sites in the state, as well as those with potential for becoming fully restored and interpreted spaces. Despite the commendable efforts to find grants and complete projects, the large number of sites and lack of adequate funding means that the fields of preservation and public history in house museums are still in crisis. For this reason, I wanted to write an academic narrative of the history of my two case studies, and physically contribute to reinterpretation projects occurring at those sites today. I also sent each finished case study chapter to staff members at those sites for final review and editing suggestions. This ensured that all the information provided was as accurate and current as possible prior to submittal.

The main framework of preservation history and four factors that affect historic house museums provided several arguments about the field in Oregon. First, I outlined the history of three past movements in preservation, from early philanthropy to the National Historic Preservation Act to rethinking the effects of gentrification. Scholarly research on how preservation of historic homes developed over time provided context as to why house museums around the country are undergoing reevaluation today. Professionals of the current fourth preservation movement are actively applying lessons of the past and transforming their sites, experimenting with policies and practices that create an open and inviting, educational and inspiring place where anyone can find connection and understanding about their own lives, neighborhood and the larger world.

Next, I argued that the current method of reinterpreting historic house museums is a complicated and ongoing, but necessary, process to preserving physical sites, safeguarding their futures, and finding a meaningful place for them in the community. 
Reinterpretation includes not only preserving collections and reorganizing the house but researching and presenting broader context and programming. The public wants to be involved with and proud of their local, state, and national historic sites, but if professionals want to garner support and repeat visitation, they must be willing to branch out in narrative and invite contemporary perspectives. Both case studies presented here are models for participating in present changes in methodology, one with an individual society project and the other through partnership.

\section{At the Stevens-Crawford Heritage House, Johna Heintz and Jenna Barganski}

participated in the current movement using the current method of reinterpretation, which as mentioned above, is a project perpetually in progress. They have accomplished goals by working with volunteers and interns to preserve and catalog collections, re-arrange rooms to original use, and conduct research about the Crawford and Stevens families, and completed repairs, among other tasks. Narrative has evolved from a male centered, architectural view to focusing on all members of the family, the innovations and add-ons that make the house unique to the Progressive-Edwardian era and how the neighborhood fits into national history.

\section{At Hollinshead Park, Kelly Canon-Miller with Deschutes County Historical Society,} along with Julie Brown and Kim Johnson at Bend Park and Recreation District, all took a leap by teaming up to reinterpret the homestead house and tack shed. Sharron Matson Rosengarth, descendant of the sharecropping family, provided additional support by sharing her personal memory, not only about her childhood but the restoration of the property over time. The Hollinshead-Matson site has completed the inventory and has 
begun working with collections and researching the history of the site. Next steps include re-arranging the rooms, re-curating displays and writing interpretive panels that include the entire history of the property, honoring all the people that helped shape it over time. ${ }^{248}$ The goals to preserve collections, by moving sensitive items to better storage, and to re-curate the house were the same as the Stevens-Crawford site, even if completed in different ways.

I also argue that public access and engagement, simultaneous to the method of reinterpretation, should be important to securing a successful place for each unique historic house museum in Oregon. As noted earlier, access refers not only to physically opening sites to the public, but providing digital information to the larger outside world, to educate a wider audience, raise awareness and accumulate support. Organizations cannot reap the fiscal benefits without first sowing seeds of emotional inspiration in stakeholders, which is why professionals like Kuri Gill are pushing for more contextual interpretations, better outreach, and new partnerships.

Access to the Stevens-Crawford Heritage House in the past has been limited, not because the house was not open, but due to the clutter, dust, and regulated guided tour. After the 2018 reinterpretation, the re-opening of the house changed that experience, allowing visitors to wander, touch, and ask at leisure. The creation of videos by a public history class and digitization of records were beneficial, but more digital assets will enhance the online presence of the site. Physical engagement and promotion outside the

\footnotetext{
${ }^{248}$ The last group email that I received from team members was dated May 15, 2021. It stated that the team has completed much of the collections preservation and restaging of furniture and are now working on the research and narrative interpretation. I will return to Bend in summer 2021 to check up on the site and offer help.
} 
site are also crucial next steps, to search the needs of the community, create partnerships with other organizations in the McLoughlin District and participate in the Willamette Falls Landings and Heritage Area project.

Research into board capacity was limited because I was not a staff member at the sites and was not privy to inner workings. However, current scholars all agree that a responsible and accountable board that efficiently plans and carries out its legal responsibilities is imperative to effective stewardship in any organization, historic or otherwise. In Oregon, the overall capability of the board of a historic house museum all depends on the type of site they care for, or where it lands on the spectrum outlined in chapter one. As a professional that has worked with several non-profits in the Portland Metro area, I have seen small boards that care immensely about their sites, but do not have the networking capabilities or funding support to accomplish projects. I have seen boards that ignore issues and lean on staff to solve problems when they should be out talking with government entities and doing capital campaigns. On the other hand, boards like those involved in my two case studies have purposefully decided to open to new opportunities for reinterpretation and creative partnerships. At the Stevens-Crawford house, the board approved the method presented by Johna Heintz and Jenna Barganski, supporting them in the basic plan. They supported funding efforts and even moved furniture. Hollinshead-Matson Historic House and Tack Shed has the benefit of two boards to ensure success, they have staff members that have made a good team and worked with former residents and interns to accomplish collections preservation and new research. 
Lastly, I argue that while securing funding is often elusive and frustrating to find, grants are not the only way to find money. They are indeed important, and time must be taken to plan, budget and carefully submit proposals, but there are other ways to find funding and raise donations for projects. For example, local businesses can donate services and products, especially storage and curation supplies, repairs, and maintenance. Various groups and clubs often need spaces to hold events and deals can be made to reciprocate the space for volunteer service or donations.

The Stevens-Crawford site was itself a donation to the Clackamas Historical Society, out of which a museum and community space was developed. The site did not bring much revenue for decades, except through occasional donations, which funded the property taxes, repairs, and maintenance through the larger budget. The goal of reinterpreting the site meant possibilities for new sources of revenue, like renting out rooms to small businesses or the garden for events like weddings. The society needs aid right now, as Covid-19 closures and the replacement of their heating and air conditioning system cut a deeply into their budget. While the main museum is now back open at limited capacity, the hope is to re-open the house in the summer and resume the plan to reach out for public commentary and support, while also continuing to improve the site.

Like the above, the property owned by Dean and Lily Hollinshead was also a donation, in this case to the Bend Park and Recreation District for a public park. The district was successful in restoring the barn and park grounds in the 1980s, but little money was invested into the house or tack shed. To honor the wishes of the owners, the buildings were preserved as a house museum. Acquiring grant money to restore the house in 1998 
was beneficial to its sustainability on park property, but it was up to Tony and Sharron Rosengarth to supply labor and accomplish the goal of a creating and running a museum. Now that Tony has passed and Sharron wants to pass the torch, the park district is faced with a new challenge. It is commendable that rather than continue to ignore the site, the park district partnered with the best possible ally in the historical society.

The partners have proved that they can be successful in finding grants and rethinking their site, which leaves no reason why they cannot finish immediate projects like restaging, installing a pathway and ramp in front and removing the crab apple tree. The challenge will be to ensure money is available to staff the site and innovate new types of programming, which can be found not just with grants, but through expansion of partnerships with organizations and businesses in the area. By creating a wider group of professionals that can share agendas and help promote one another, more information could be made available about the site to increase financial interest. Educational school tours could be funded through fairs and markets, or even providing access during wedding events (for an added cost). With persistence and creative thinking, the networking options are limitless.

This thesis contributes to the current movement in heritage preservation and the push to reinterpret historic house museums. However, it is important to remember that there are still many sites that need partnership and support. Restoration and reinterpretation projects must be implemented before they can begin long term public engagement and become fully interpreted public sites that bring in revenue. Actions that are taking place in house museums across the country today are significant because they are drawing from 
past movements, for lessons on how to present diverse and contextual narratives, make improvements to standard collections policy and fiscal practice, and especially to tap into public agency.

Conducting fieldwork and site visits in three counties in Oregon proved that the need the reimagine historic house museums is not centralized and shows a clear and consistent demand all over the state. The Stevens-Crawford and Hollinshead-Matson properties are in the process of change, but to fully reimagine these sites, a commitment to funding, staffing, and programming is necessary in perpetuity. It is easy to envision a future where each community respects and saves their history by incorporating it into modern development, bringing an unbroken existence back into their regions. Increased momentum is the future of this current movement, to re-create our historic house museums, include as many places and perspectives as possible, and to show Americans that they can connect to, understand, and be proud to share in the past. 


\section{$\underline{\text { References }}$}

\section{$\underline{\text { Archival Sources }}$}

Annual report 2019, "Letter to CCHS Members and Friends," (Clackamas County Historical Society, Oregon City, Oregon), 4. Link:

https://drive.google.com/file/d/1zgD_ja2ttO-9y-dALBGbDnYZgfe0Q6ft/view.

Board of Directors, Meeting Minutes: 1950-1970 (Clackamas County Historical Society, Oregon City, OR), Accessed Fall 2020.

Heintz, Johna, "SCHH.pdf," Archival PDF (Clackamas County Historical Society, Oregon City, Oregon) Accessed Fall 2020.

Heintz, Johna, The Stevens Family: A Brief History, Power Point presentation, (Clackamas County Historical Society, Oregon City, Oregon) Accessed Fall 2020.

"Hollinshead file," Deschutes County Historical Society Archive, Bend, Oregon, Accessed August 2019.

"Hollinshead Collection," Bend Park \& Recreation District, Bend, Oregon, Accessed August 2019.

Letter from the office of Carrie Whitaker, Executive Director of BPRD, ORPA Volunteer Service Award nomination for Sharon and Tony Rosengarth, 1998 (Bend Park and Recreation District, Bend, Oregon), Accessed August 2019.

Lowery, Paula, "Hollinshead History" (Deschutes County Historical Society: Bend, Oregon, May 2000).

Memo of Understanding, Bend Park and Recreation District and Deschutes County Historical Society, dated May 2, 2019 (Deschutes County Historical Society, Accessed August 2019).

National Historic Preservation Act, 54 U.S.C. §§ 300101-307108, Section 1 (16 U.S.C 470), 1966.

Oregon City McLoughlin Conservation District 2002 Resurvey Final Report, Revised December 2003. (Historic Preservation Northwest: Prepared for the City of Oregon City).

Rosengarth, Tony, Email to Ed Moore, dated December 12, 2011 (Bend Park and Recreation District), Accessed August 2019. 
Schade, Liza, Johna Heintz interview, Oral history: notes from raw footage, Public History class, Dr. Katy Barber, Portland State University, Created Fall 2018.

Stevens Crawford Heritage House: Basic Guidelines for Docents (Clackamas County Historical Society, Oregon City, Oregon), Accessed Fall 2020.

\section{Newspaper Sources}

"Car Wreck Caused by Speeder Ends Lives; Mrs. George Jones Unwilling to Survive Husband," The Bend Bulletin, July 10, 1924. Accessed on April 20, 2021.

Newspapers.com link:

https://www.newspapers.com/image/94799317/?terms=George\%20Jones\&match=1.

Criteser, Vera, "Property Given to Historical Group," The Oregonian, September 9, 1959, (Medorem Crawford file: Clackamas County Historical Society, Oregon City, Oregon), Section 3, Pg.1.

"Interior Canal Work," East Oregonian (Pendleton, OR), March 02, 1905.

Newspapers.com link:

https://www.newspapers.com/image/174326776/?terms=F.C.\%20Rowlee\&match=1.

Kimmelman, Michael, "When the Old Penn Station was Demolished, New York Lost its

Faith: Today's version is humiliating and bewildering," New York Times, April 24, 2019 (Accessed 04/01/2021). Link: https://www.nytimes.com/2019/04/24/nyregion/old-penn-stationpictures-new-york.html.

Klampe, Michelle L., "Making a House a Home," The Bend Bulletin, 1998 (Hollinshead file: Clackamas County Historical Society, Oregon City, Oregon), Accessed August 2019.

Ling, Jack “Kirk Douglas in Bend for Film," Bend Bulletin, May 21, 1955, Historic Oregon Newspapers, Downloaded May 20, 2020).

"Long Resident of the Area Dies," Obituary for Cecil Hollinshead, Bend Bulletin, May 25, 1956 (Hollinshead file: Deschutes County Historical Society, Bend, Oregon), Accessed August 2019.

McCue, Dan, "Oregon Trail a paper trail, too," The Oregonian, June 10, 1993 (Medorem Crawford file: Clackamas County Historical Society, Bend, Oregon).

"Mrs. Hollinshead Injured at Ranch," The Bend Bulletin, December 12, 1950 (Deschutes County Historical Society, Bend, Oregon), Accessed August 2019. 
Obituary, "Death Calls Mary Stevens Local Pioneer: Well Known Local Woman Succumbs After Illness of Several Weeks; Funeral Sunday," Unknown Newspaper (Crawford Family File: Clackamas County Historical Society, Oregon City, Oregon), Accessed Fall 2020.

Obituary, "Lily B. Hollinshead," Unknown Newspaper, July 23, 1990 (Hollinshead file: Bend Park and Recreation District, Bend, Oregon), Accessed August 2019.

Obituary, "Oregon City Man of Note is Dead," Unknown Newspaper (Stevens Family file: Clackamas County Historical Society, Oregon City, Oregon), Accessed Fall 2020.

"Plans Told for Housing Development," The Bend Bulletin, Bend, Oregon, July 20, 1959 (Newspapers.com: Accessed April 2020).

"Teacher Retires, Will Teach Horses Instead of Children," Unknown Newspaper and date (Hollinshead file: Clackamas County Historical Society, Oregon City, Oregon), Accessed August 2021.

"Timberlane Holds Buckaroo Breakfast," The Bend Bulletin, May 6, 1950 (Hollinshead file: Clackamas County Historical Society, Bend, Oregon), Accessed August 2019.

\section{$\underline{\text { Secondary Sources }}$}

Ashton, Paul, and Alex Trapeznik (Eds.), What is Public History Globally? Working with the Past in the Present (Bloomsbury Academic: NY, 2019).

Beaulieu, Rebekah, Financial Fundamentals for Historic House Museums (Rowman \& Littlefield: Lanham, Maryland, 2017).

Bosco-Milligan Foundation, Issuing Body, and Oregon. State Historic Preservation Office, Sponsoring Body. Cornerstones of Community: Buildings of Portland's African American History. Revised \& Expanded. ed. Portland, OR: Bosco-Milligan Foundation, 1997

Boyd, Douglas A., and Mary Larson (Eds.), Oral History and the Digital Humanities (Palgrave MacMillan: New York, 2014).

Burns, Andrea, From Storefront to Monument: Tracing the Public history of the Black Museum Movement (University of Massachusetts Press: Amherst and Boston, 2013).

Burns, Andrea, Resource or burden? Historic House museums confront the $21^{\text {st }}$ century, National Council on Public History website article, January 13, 2015.

Link: https://ncph.org/history-at-work/resource-or-burden/ 
Cauvin, Thomas, Public History: A Textbook of Practice (New York: Taylor \& Francis, 2016.

Congressional Research Service, National Monuments and the Antiquities Act, CRS Report: Prepared for Members and Committees of Congress, Updated November 30, 2018 (Pg. 2).

Conrad, David E., "Tenant Farming and Sharecropping," The Encyclopedia of Oklahoma History and Culture, https://www.okhistory.org/publications/enc/entry.php?entry=TE009.

Conrad, David E., The Forgotten Farmers: The Story of Sharecroppers in the New Deal (Urbana: University of Illinois Press, 1965.

Dagbovie, Pero Gaglo, “'Most Honorable Mention...Belongs to Washington D.C.:' The Carter G. Woodson Home and the Early Black History Movement in the Nation's Capital," The Journal of African American History, Vol. 96, No., pp. 295-324 (Summer 2011).

Davidson, Hugh Roe, Bent to Nature: Bend, Oregon as a Case Study in Twentieth Century Property Development, PSU Dissertation, December 2005.

Duberow, Bernard G., History of Hollinshead Park (Formerly Timberlane Ranch): From the time of Original Settlement Through the Complete Acquisition Process for Development as a Park (Deschutes County Historical Society Archive, Bend, Oregon), revised 10/08/1985.

Gray, Oscar S. "The Response of Federal Legislation to Historic Preservation." Law and Contemporary Problems, Vol. 36, no. 3 (1971): 314-28.

Harris, Donna Ann, New Solutions for House Museums: Ensuring the Long Term Preservation of America's Historic Homes (Rowman \& Littlefield: Lanham, MD, 2007).

Howe, Barbara, "Women in Historic Preservation: The Legacy of Ann Pamela Cunningham,” The Public Historian, Vol. 12. No. 1 (Winter 1990): 31-61.

Hurley, Andrew, Beyond Preservation: Using Public History to Revitalize Inner Cities (Temple University Press: Philadelphia, PA, 2010).

Johnson, Joan Marie, "Ye Gave Them a Stone:" African American Women's Clubs, the Frederick Douglass Home and the Black Mammy Monument, Journal of Women's History, Vol. 17. No.1 (2005). 
Johnson, Karen, "Pilot Butte State Scenic Viewpoint," Oregon Encyclopedia, Portland: Oregon Historical Society, Accessed April 2021. Link:

https://www.oregonencyclopedia.org/articles/pilot_butte_state_scenic_viewpoint/\#.YIhf2 $\underline{\mathrm{C} 2 \mathrm{z} 3 \mathrm{BI}}$

King, Thomas, Cultural Resource Laws \& Practice, Fourth Edition (New York: Alta Mira Press, 2013.

Lawrence, Charles William, "New Neighbors in Old Neighborhoods: Explaining the Role of Heritage Conservation in Sociocultural Sustainability and Gentrification" (2010) Thesis (Historic Preservation). 75 Link: http://repository.upenn.edu/hp_theses/145.

Moe, Richard, “Are There Too Many House Museums?” Forum Journal (Vol. 27, Number 1, Fall 2012).

Nash, Tom, Federal Writers Project in Oregon, (Oregon Encyclopedia: Oregon Historical Society). Link:

https://www.oregonencyclopedia.org/articles/federal_writers_project_in_oregon/\#.YFviL y2z3BI

Page, Max and Marla R. Miller (Eds.), Bending the Future: 50 Ideas for the Next 50 Years of Historic Preservation in the United States (University of Massachusetts Press: Boston, 2016).

Rosengarth, Sharron Matson, Little Country Girl: Stories \& Memories of Life at the Hollinshead Ranch (Booklet: Bend Park \& Recreation District, Bend, Oregon).

Rosenzweig, Roy and David Thelen, The Presence of the Past (New York: Columbia University Press, 1998).

Simon, Nina. The Participatory Museum. (Santa Cruz: Museum 2.0, 2010). Link: http://www.participatorymuseum.org/preface/

The WPA Guide to 1930s Iowa (Federal Writers Project: University of Iowa Press), 1938.

Turino, Kenneth C. and Max A. Van Balgooy (Eds.), Reimagining Historic House Museums: New Approaches and Proven Solutions (Rowman \& Littlefield, 2019).

Tyler, Norman and Iilene R. Tyler and Ted J. Ligibel, Historic Preservation: An Introduction to its History, Principles and Practice (WW. Norton \& Co.: New York, 2018). 
Vagnone, Frank D. and Deborah Ryan, Anarchist's Guide to Historic House Museums: A Ground-Breaking Manifesto (Left Coast Press: Walnut Creek, CA, 2016).

Wilson, Mabel O., Negro Building: Black Americans in the World of Fairs and Museums (University of California Press, 2012),

$\underline{\text { Web Sources }}$

"Mission Statement: History section," Central Oregon Irrigation District, Accessed April 2021.

Link: https://coid.org/about-us/

"DAR History,” Daughters of the American Revolution, Accessed 2021. Link:

https://www.dar.org/national-society/about-dar/dar-history

Deschutes County Public Records Center, Land deed records for J.H. Bean (Accessed April 2021). Link:

https://weblink.deschutes.org/Public/Welcome.aspx?dbid=0\&repo=LFPUB

Find a Grave, database and images (https://www.findagrave.com: accessed 27 March 2021), memorial page for Harley C. Stevens (7 Jan 1847-27 Jul 1924), Fina. Grave Memorial no. 93269690, citing Mountain View Cemetery, Oregon City, Clackamas County, USA; Link: https://www.findagrave.com/memorial/93269690/harley-c-stevens.

McLoughlin Conservation District, City of Oregon City website.

Link: https://www.orcity.org/planning/mcloughlin-conservation-district.

National Park Service, National Register Database and Research webpage, Accessed April 2020. Link:https://www.nps.gov/subjects/nationalregister/database-research.htm.

OPB Oregon Experience, "Reub Long's Oregon Desert," Link:

https://www.pbs.org/video/oregon-experience-reub-longs-oregon-desert/.

Oregon State Historic Preservation Office, Oregon Museum Grant Information, Accessed April 2020. Link:

https://www.oregon.gov/oprd/OH/Documents/MuseumGrantInformation2020.pdf.

Our History (Clackamas County Historical Society, Oregon City, Oregon), Accessed Fall 2020.

Link: http://clackamashistory.org/our-history.

National Historic Preservation Act of 1966, as amended through 1992, National Register of Historic Places, Criteria for evaluation (36 CFR Part 60.4). Link: https://www.nps.gov/history/local-law/nhpa1966.htm. 
"National Treasures: Our nation's historic places reveal the richness of the American Story," National Trust for Historic Preservation, Accessed Fall 2020. Link:

https://savingplaces.org/national-treasures

"Peter Byberg House," National Register of Historic Places Nomination Form, Nov. 28, 1998 (Accessed April 2021). Link:

https://www.bendoregon.gov/Home/ShowDocument?id=6195

Public History PDX, "Junk in the Trunks: Reinterpreting the Stevens-Crawford Heritage House," (Portland State University History Department, February 25, 2019). Link:

http://publichistorypdx.org/2019/02/25/junk-in-the-trunks-reinterpreting-the-stevenscrawford-heritage-house/.

"Preparing National Register Nominations in Oregon" Oregon State Parks Department, Accessed Winter 2020, pg. 1.

Link:https://www.oregon.gov/oprd/OH/Documents/08_18_NR\%20Handbook.pdf.

Schade, Liza, "Hollinshead Homestead House," Created Fall 2019. Posted online June 9, 2020.

YouTube Link: https://www.youtube.com/watch?v=s_VHcfdhxCk

“Thomas Jefferson Foundation Overview," Monticello website, Accessed Winter 2020. https://www.monticello.org/thomas-jefferson-foundation/thomas-jefferson-foundationan-overview/

Vamonde.com, "An Introduction: Welcome to the Stevens Crawford Heritage House," Link: https://www.vamonde.com/posts/an-introduction-welcome-to-the-stevenshouse/9911/.

"Our Coalition" Willamette Falls \& Landings Heritage Area Coalition, webpage, Accessed April 2021. Link: https://www.wflha.org/about/.

Wrenn, Sarah, List of WPA interviews, Library of Congress. Accessed April 2021. Link:https://www.loc.gov/search/?fa=contributor:wrenn,+sara\&sp=1.

Wrenn, Sara B. and Miss Mertie Stevens, Federal Writers Project: Early Oregoniana and Local Sayings, Oregon, 1939. Manuscript/ Mixed Material. https://www.loc.gov/item/wpalh001977/.

2011 City-wide Historic Survey: An Oregon Heritage Excellence Winner, City of Oregon City. Link: https://www.orcity.org/planning/request-proposal-historic-survey-0. 